\title{
A ARTE DE CONTAR: UMA INTRODUÇÃO AO ESTUDO DO VALOR DIDÁTICO DA HISTÓRIA DA MATEMÁTICA
}

ANTONIO CARLOS BROLEZZI

Dissertação de Mestrado apresentada ao Departamento de Metodologia do Ensino e Educação Comparada da Faculdade de Educação da Universidade de São Paulo, sob orientação do Professor Doutor Nílson José Machado.

SÃO PAULO 
Não é por acaso que os verbos "contar" (números) e "contar" (histórias) apresentam freqüentemente a mesma raiz etimológica: em alemão se diz zahlen e erzalen; em holandês, tellen e vertellen; em italiano, espanhol e português usa-se contar para ambos; em francês arcaico, o verbo conter era igualmente empregado nos dois sentidos; e, em hebreu, o verbo saphor ("contar, calcular") tem o mesmo radical que saper ("contar história") 1 .

\section{Conteúdo:}

\section{Introdução}

Capítulo 1. Breve História das Fontes da História da Matemática

1.1. Valor das Fontes Históricas no Estudo da História da Matemática

1.2. Caminhos da História da Matemática Pré-Helênica

1.3. Tradição Greco-Latina

1.4. De Boécio a Gerbert

1.5. O Renascimento no Século XII

1.6. O Advento dos Livros de História da Matemática

Capítulo 2. Tipos de Livros de História da Matemática

2.1. Cronologias

2.2. Biografias

2.3. Por Assunto

2.4. Outros

Capítulo 3. O Valor Didático da História da Matemática

3.1. História da Matemática e Lógica da Matemática em Construção

3.2. História da Matemática e Significado

3.3. História da Matemática e Visão da Totalidade

Conclusões

Apêndice: Experiências de Alguns Cursos

Bibliografia Geral

Bibliografia Específica Sugerida ${ }^{1}$ Georges Ifrah. Os Números: a História de uma Grande Invenção. Trad. de Stella Maria de Freitas Senra. Rio de
Janeiro, Globo, 1989. 367 p., p. 221. 


\title{
INTRODUÇÃO
}

\author{
É de se esperar que as pessoas \\ queiram aprender de nós como e em que ordem as \\ descobertas matemáticas se sucederam umas às \\ outras, e seria nosso dever ensiná-las. Foi feita a \\ História da Pintura, da Música, da Medicina, etc. \\ Uma boa História da Matemática, em particular da \\ Geometria, seria uma obra mais curiosa. Que \\ prazer não se teria ao ver a ligação, a conexão dos \\ métodos, o encadeamento das diferentes teorias \\ começando desde os primeiros tempos até o \\ nosso, no qual essa Ciência se encontra \\ transportada a tão alto grau de perfeição! ${ }^{1}$
}

O texto acima retrata muito bem a antigüidade da preocupação pela difusão do conhecimento sobre a História da Matemática. Trata-se de trecho de uma carta dos fins do século XVII, escrita pelo cavalheiro francês Montmort a um dos matemáticos da família Bernoulli. Mas poderia ter sido produzido em pleno século XX, salvo alguma pequena alteração de estilo, pois retrata uma situação muito atual principalmente para Professores de Matemática elementar. Passados trezentos anos, apesar de haver muitos livros de História da Matemática, poucos são acessíveis. Sua aplicabilidade didática também é uma questão que só recentemente passou a ser discutida com mais vigor.

Há, portanto, nessa área, uma lacuna a ser preenchida, uma vez que a Matemática tem História. Como qualquer outra Ciência, não é estática, mas evolui ao longo do tempo. O conhecimento matemático de um século atrás diferia muito do de hoje, assim como eram diferentes a Biologia, a Física e as próprias Línguas faladas ou escritas. Essa evolução das idéias matemáticas dificilmente se percebe pela simples observação do estado atual da Matemática. Para poder conhecer sua História, é preciso transcender o âmbito específico do conhecimento matemático. Percorrer caminhos outros que não os das definições, teoremas e demonstrações.

Esse distanciamento entre a Matemática ensinada hoje nas escolas e seu desenvolvimento ao longo do tempo reforça a idéia de que a Matemática, considerada a Ciência exata por excelência, está muitas vezes associada a um falso imobilismo, que nenhuma Ciência de fato apresenta. Na verdade a Matemática está muito viva. Já alertava Florian Cajori, há um século:

É possível ao professor deixar claro para o aluno que a Matemática não é uma Ciência morta, mas uma Ciência viva na qual um progresso contínuo é realizado².

Uma Matemática viva, em progresso, ou seja, em construção, surge aos olhos dos alunos quando se recorre à História da Matemática. Mas esse recurso não é tarefa trivial. Faltam, como dissemos, informações históricas adequadas ao ensino da Matemática elementar. Além disso, há o perigo de se ficar na superficialidade de uma utilização de fatos da História da Matemática como meras curiosidades sem nenhuma implicação no tratamento dos conteúdos matemáticos em si.

Para preencher a lacuna existente entre o ensino de Matemática elementar e a História da Matemática, pretendemos aqui sugerir algumas linhas básicas de pesquisa que podem levar a uma abordagem na qual o próprio conteúdo seja influenciado pelo uso da História da Matemática em sala de aula. Não se trata apenas de ilustrar as aulas de Matemática com histórias que divirtam, como biografias de matemáticos famosos. Nem simplesmente de acrescentar mais conteúdo ao currículo elementar de Matemática, para recheá-lo de referências históricas diretas que de algum modo ajudem a demonstrar a importância ou a beleza do assunto que se quer ensinar. O que pretendemos fazer aqui é

\footnotetext{
1 MONTMORT, Carta a Bernoulli. Apud LORIA, Gino. Guida allo Studio della Storia delle Matematiche. $2^{\mathrm{a}}$ ed. Milano, Ulrico Hoepli, 1946. 385 p., p. 19, nota 1.

2 CAJORI, Florian. The Teaching and History of Mathematics in the United States. Washington, 1890. p. 236. Apud CAJORI, Florian. A History of Mathematics. New York, The MacMillan Company, 1919. 516 p., p. 3.
} 
contribuir para o estudo de uma utilização muito mais profunda do recurso à História da Matemática.

Esse estudo deveria levar em consideração a existência de um encadeamento lógico característico na construção do conhecimento científico e outro na sistematização, na formalização desse conhecimento. A nosso ver, a ordem lógica mais adequada para o ensino de Matemática não é a do conhecimento matemático sistematizado, mas sim aquela que revela a Matemática enquanto Ciência em construção. $O$ recurso à História da Matemática tem, portanto, um papel decisivo na organização do conteúdo que se quer ensinar, iluminando-o, por assim dizer, com o modo de raciocinar próprio de um conhecimento que se quer construir.

Essa abordagem constitui-se no cerne desse estudo sobre o valor didático da História da Matemática, embora também façamos referência a outras funções do recurso à História da Matemática. Podemos chamar essa abordagem de Arte de Contar, pois contar em diversas línguas se aplica tanto a contar histórias quanto a contar objetos. Desse modo queremos expressar nossa intenção de contribuir para que não se considerem o ensino da Matemática e a História da Matemática como compartimentos estanques, revelando a existência entre eles de uma relação intrínseca que une o conhecimento matemático construído na História e o reconstruído nas aulas de Matemática.

Para proceder a esse estudo, sugerimos recorrer diretamente às fontes da História da Matemática. Dentro das tendências atuais da historiografia, está ocorrendo um retorno à valorização das fontes genuínas, às narrativas de pequenos acontecimentos e da vida de algumas pessoas concretas, para a partir daí compreender a mentalidade e a cultura de uma época passada. De modo especial, essa abordagem se aplica à tentativa de reconstituição das causas que determinaram o surgimento de tópicos específicos da Matemática, através da análise dos indícios registrados pelas fontes. Assim, sugerimos entrar em contato o mais diretamente possível com pormenores significativos que evidenciam o modo de pensar peculiar dos protagonistas da História da Matemática. As razões que levaram à elaboração de um resultado matemático podem ser múltiplas e complexas. Sejam como forem, é nas fontes originais que essas razões são melhor encontradas, pois são as mais próximas testemunhas da gênese daquela idéia matemática.

Em síntese, a proposta desse trabalho é servir de introdução ao estudo acerca do uso da História da Matemática enquanto fornecedora dos elementos necessários para a construção de caminhos lógicos tendo em vista a construção original daquele tópico matemático que se quer ensinar, propiciando ao aluno uma visão com significado da totalidade da matéria. A proposta inclui uma caracterização dos meios de se obter conhecimentos sobre História da Matemática através do recurso às fontes históricas e aos vários tipos de livros de História da Matemática.

Iniciaremos com uma retrospectiva da transmissão de conhecimentos sobre História da Matemática, reconhecendo os principais documentos disponíveis para conhecer essa História. No primeiro capítulo veremos uma História dessas fontes. Conforme veremos, os livros sobre História da Matemática não são a única fonte de informação sobre ela. Muitas vezes temos de recorrer a textos originalmente matemáticos. Por isso, nessa primeira capítulo trataremos indistintamente de escritos matemáticos historicamente importantes e de escritos exclusivos de História da Matemática.

No segundo capítulo estudaremos com mais pormenor alguns livros específicos sobre História da Matemática, segundo sua divisão por tipos (cronologias, biografias, por assunto e outros). O modo como o livro está organizado é importante para definir a estratégia de sua utilização didática. No estudo desses livros, a estrutura do seu conteúdo como um todo é tão reveladora que pareceu-nos conveniente trabalhar também com a própria relação de conteúdo de alguns livros, a fim de apreendermos adequadamente sua organização interna. Os objetivos dos autores desses livros, expostos em suas análises introdutórias, também serão considerados, pois esclarecem a concepção de livro de História da Matemática do autor em questão.

Tendo por base o estudo dos capítulos anteriores sobre as fontes e os livros de História da Matemática, no terceiro capítulo faremos uma exposição dos principais componentes do valor didático da História da Matemática. Esperamos assim construir um panorama das principais linhas de pesquisa que deveriam ser abordadas num estudo sobre o tema. Por fim, nas conclusões, recolheremos, de forma sucinta, os principais fatos abordados no trabalho. 


\title{
CAPÍTULO 1 \\ Breve História das Fontes da História da \\ Matemática
}

\subsection{Valor do recurso às Fontes da História da Matemática}

\begin{abstract}
Uma coisa é escrever como poeta, e outra como historiador; o poeta pode contar as coisas não como foram, mas como deviam ser, e o historiador há de escrevê-las, não como deviam ser, mas como foram, sem acrescentar nem tirar à verdade a mínima coisa.

Cervantes $^{3}$

A história é uma aventura espiritual em que a personalidade do historiador se compromete por completo.
\end{abstract}

Marrou $^{4}$

Para estudar o valor didático da História da Matemática é necessário inicialmente conhecer essa História, sendo esse conhecimento construído fundamentalmente à partir do contato com suas fontes. $O$ acesso às fontes históricas é de grande utilidade para a construção do conhecimento histórico em geral. De modo especial, para a construção do conhecimento específico sobre História da Matemática, as fontes representam um papel muito importante.

O historiador francês Henri-Irénée Marrou, em sua obra Sobre o Conhecimento Histórico, explica que o valor do recurso às fontes deve-se principalmente ao fato de o passado não poder ser alcançado diretamente, mas apenas na medida em que reencontramos os traços que ele deixou atrás de si, e também na medida em que formos capazes de interpretá-los, isto é, torná-los inteligíveis para nós ${ }^{5}$. Isso faz com que a história seja sempre feita com documentos, que são para a história como o combustível para o motor à explosão6. Desse modo, muitas das questões que poderiam interessar o historiador podem permanecer sem resposta por falta de documentação suficiente. Incluída no processo de construção da história está a explicação, ou a interpretação dos dados documentais feita pelo historiador:

A explicação em história é a descoberta, a apreensão, a análise dos mil laços que, de modo talvez inextrincável, unem umas às outras as múltiplas faces da realidade humana - que ligam cada fenômeno aos fenômenos vizinhos, cada estado a antecedentes, imediatos ou longínquos, e, similarmente, às suas conseqüências ${ }^{7}$.

Essa explicação, elaborada pelo historiador, constitui-se em teorias, as quais são sempre elaboradas tendo em vista um problema particular e limitado. Posteriormente, essa hipótese explicativa pode ultrapassar seu domínio original, e pretender assim reconstruir a realidade histórica de acordo com esse sistema escolhido previamente ${ }^{8}$. Mas o campo de atuação das explicações históricas é limitado, havendo um nível determinado no qual se estabelece a validade da história ${ }^{9}$. Existe sempre o risco de enfatizar

\footnotetext{
3 CERVANTES, Miguel de. O Engenhoso Fidalgo Dom Quixote de la Mancha. Tradução de Viscondes de Castilho e Azevedo. São Paulo, Abril Cultural, 1978. 609 p., p. 325

${ }^{4}$ MARROU, Henri-Irénée. Sobre o Conhecimento Histórico. Tradução de Roberto Cortes de Lacerda. Rio de Janeiro, Zahar Editores, 1978. 265 p., p. 164

5 Cf. Ibid., p. 55

6 Cf. Ibid., p. 56

${ }^{7}$ lbid, p. 147

8 Cf. lbid., p. 155

9 Cf. Ibid., p. 160
} 
a contribuição do historiador na produção do conhecimento histórico, em detrimento do valor das fontes documentais. É claro que, como afirma o mesmo autor, a história é o resultado do esforço criador de estabelecer relações entre o passado e o presente ${ }^{10}$. Já desde o início, ao selecionar o tema de pesquisa, ao escolher as fontes e ao interpretá-las, o historiador compromete sua personalidade, numa ação criadora. Mas essa contribuição criadora do historiador na elaboração da história não deve ser nunca encarada como um jogo gratuito, a livre utilização da imaginação que lida com textos, datas, gestos e palavras como o faz um escritor de ficção ou um poeta.

É necessário tomar cuidado para nunca superestimar uma teoria ou explicação histórica, evitando extrapolações para campos por demais amplos. As observações de caráter geral, às vezes chamadas de "leis da história", nada mais são que semelhanças parciais sobre alguns aspectos do passado, de acordo com o ponto de vista momentâneo do historiador ${ }^{11}$. Marrou chama a atenção para 0 fato de que a realidade histórica, que captamos na análise dos documentos, constitui-se em fenômenos singulares, únicos e irrepetíveis, entre os quais existem analogias que entretanto só incidem em aspectos parciais, abstraídos pela análise mental, e não englobam aspectos gerais da realidade histórica na sua totalidade.

A conclusão é que o fundamental na tarefa do historiador é justamente a compreensão, das Verstehen, das fontes:

Empiricamente observada, a compreensão aparece como a interpretação de sinais (...) ou de indícios (cinzas de um fogo, impressões digitais) através de cuja realidade imediata conseguimos alcançar alguma coisa do homem de outrora: sua ação, seu comportamento, seu pensamento, seu ser interior ou, ao contrário, às vezes simplesmente sua presença (um homem passou por aqui) ${ }^{12}$.

Já se vê que as fontes históricas vão muito além de simples documentos escritos. A história pode fazer-se com documentos escritos, quando existem, mas também com tudo aquilo que o engenho do historiador coloca ao seu alcance: sinais, pinturas, registros com fins didáticos, administrativos ou técnicos, instrumentos de uso cotidiano, exames de pedras por geólogos, análises de espadas metálicas efetuadas por químicos, etc $^{13}$.

Esse leque amplo de possibilidades de um objeto qualquer vir a tornar-se fonte histórica levou o historiador italiano Carlo Ginzburg a expor em seu ensaio Sinais: Raízes de um Paradigma Indiciário ${ }^{14}$, uma forma de conhecimento baseado nos indícios e sinais pelos quais tomamos contato com uma realidade inacessível diretamente. Segundo suas análises, um verdadeiro modelo epistemológico, ou paradigma, teria surgido por volta do final do século XIX, principalmente no âmbito das ciências humanas: Trata-se de

uma atitude orientada para a análise de casos individuais, reconhecíveis apenas através de pistas, sintomas, indícios ${ }^{15}$.

Ginzburg não concebe forma melhor de explicar esse modelo epistemológico que elaborando uma analogia com o método de conhecimento dos médicos, detetives, classificadores de arte e outras profissões nas quais o fundamental está na observação de pormenores. No caso dos procedimentos clínicos, o profissional deve observar atentamente todos os pequenos sintomas, e só assim pode elaborar "histórias" precisas da doença, que é, em si, inatingível ${ }^{16}$. Daí a existência de uma verdadeira semiótica médica, que permitiria diagnosticar as doenças inacessíveis à observação direta com base na observação de sintomas superficiais, os quais muitas vezes passam inadvertidos aos olhos do leigo ${ }^{17}$. O conhecedor de arte, por sua vez, também seria capaz de descobrir se uma pintura é autêntica ou falsificada pela observação de pormenores, como o traçado de

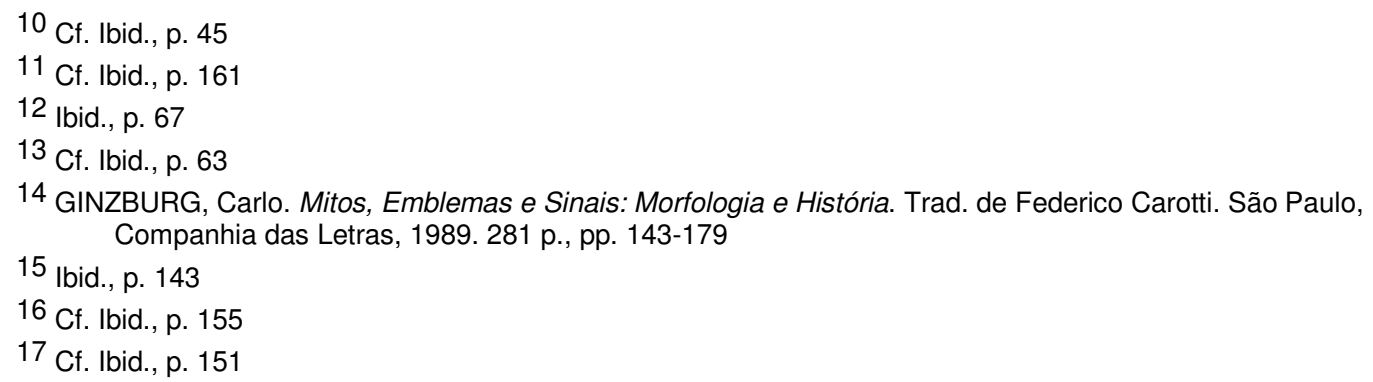


orelhas e fios de cabelo, por trás dos quais se percebe a mão do gênio ou do falsificador. A analogia com o trabalho do detetive é também evidente, pois ele descobre o autor do crime baseado em pequenos indícios, muitas vezes imperceptíveis para a maioria ${ }^{18}$. Também Marrou comenta que o inquérito policial desencadeado pela descoberta de um assassinato é um estudo de ordem propriamente histórica, procedendo através de pesquisa, crítica e interpretação de documentos, de indícios (pegadas, impressões digitais) e dos testemunhos recolhidos ${ }^{19}$.

Esse retorno às fontes históricas em busca de indícios significativos caracteriza uma verdadeira tendência recente da historiografia, apontada por Roberto J. Lopez no seu artigo Nuevas Tendencias en la Historiografia: La Vuelta al Arte de Contar 20. Lopez diz que a narração de um pequeno acontecimento ou da vida de alguns indivíduos pode servir como ponto de partida para o estudo de situações mais gerais. Desse modo, os historiadores estariam retornando à prática de contar relatos, mas esses teriam algumas diferenças com relação aos relatos tradicionais, por estarem menos centrados na narração da vida de reis, políticos, militares e gente da diplomacia, e mais nas vidas e costumes de autores anônimos da história. Dentro desse paradigma, as fontes históricas ocupam uma nova posição:

As fontes empregadas costumam ser novas, ao menos no seu uso (atas de notários, registros judiciais, sentenças); há uma estreita vinculação com a antropologia, na medida em que trata de alcançar o significado simbólico dos fatos narrados. Definitivamente, 0 que se busca é "jogar luz sobre os mecanismos internos de uma cultura ou de uma sociedade no passado"21. A história das mentalidades (...) constitui a vanguarda da nova narrativa 22 .

Portanto, nessa tendência da historiografia é dado um lugar de destaque ao acesso às fontes como forma de descobrir o significado e a lógica interna das formas de pensar, das mentalidades do passado.

De um modo especial, também para nós é conveniente recorrer às fontes da História da Matemática e aos diferentes tipos de livros que há sobre o tema, pois neles encontramos os indícios que revelam as razões do surgimento das idéias matemáticas. Além disso, mais que conhecer uma série de fatos históricos isolados, importa sobretudo que o Professor tenha claro a noção de onde obter essas informações históricas. Por um lado, porque existe uma quantidade muito grande de dados históricos, a qual vai inclusive crescendo e se modificando à medida em que se desenvolvem as pesquisas históricas. Por outro lado, conforme veremos mais adiante, fazer uso da História da Matemática para ensinar Matemática elementar não se reduz ao simples ato de contar histórias: é necessário captar a forma de pensar, a lógica da construção matemática. Isso faz com que seja fundamental para quem queira fazer uso didático da História da Matemática, conhecer primeiro suas fontes.

Embora as formas em que a História da Matemática é apresentada traduzam em parte a concepção de História do autor, não estamos aqui interessados nas diferentes teorias de explicação histórica e suas respectivas conseqüências no estudo da evolução do pensamento científico. Quando realizamos uma classificação por tipos dos livros de História da Matemática e quando esboçamos uma breve História da fontes, não estamos querendo descrever as várias posturas históricas que já surgiram, mas apenas relacionar de forma ordenada os principais escritos que servem para o conhecimento de História da Matemática, falando também um pouco de alguns autores significativos. Nossa intenção é facilitar o acesso o mais diretamente possível a essas fontes, de modo que cada qual possa extrair da análise dos relatos do fenômeno da criação científica, elementos para uma abordagem mais significativa do conteúdo que pretende ensinar, baseando-se nos indícios registrados na História.

Para facilitar esse acesso às fontes foi-nos muito útil o contato com a resenha de livros realizada por Gino Loria, em seu Guia ao Estudo da História da

\footnotetext{
18 Cf. Ibid., p. 145

19 Cf. MARROU, op. cit., p. 105

20 LOPEZ, Roberto J. Nuevas Tendencias en la Historiografía: la Vuelta al Arte de Contar. Madrid, ACEPRENSA, 16 Marzo 1988, servício $37 / 88$

21 STONE, Lawrence. El Passado y el Presente. México, Fondo de Cultura Económica, 1986, 289 p.

22 LOPEZ, o. cit.
} 
Matemática ${ }^{23}$. O objetivo de Loria ao escrever essa retrospectiva era auxiliar o pesquisador, o qual

\author{
se não quiser perder tempo e esforço ao redescobrir coisa já sabida, deve \\ antes de tudo conhecer os pontos comuns dos pesquisadores \\ precedentes, cujo ponto de chegada deve servir para ele como ponto de \\ partida ${ }^{24}$. \\ Loria pretendia orientar o futuro autor de História da Matemática,
} relacionando as obras do tipo já existentes, de modo a que ele pudesse conhecer os pontos comuns entre elas e planejar uma obra que de algum modo representasse um avanço em relação às anteriores. De fato, como diz Marrou, um trabalho histórico deve iniciar pela leitura do que já foi escrito sobre o mesmo assunto, os temas vizinhos e outros relacionados. Isso é útil sobretudo para orientar a heurística, aprendendo dos trabalhos anteriores o gênero de fontes nas quais se pode encontrar informações ${ }^{25}$.

O espírito do presente trabalho difere do de Loria, pois não visa diretamente o trabalho do historiador da Matemática. Não nos dirigimos em primeiro lugar ao pesquisador de História da Matemática em si, mas sim àqueles interessados em descobrir seu valor didático. Para nós permanece válido, porém, considerar as diferentes espécies de fontes segundo as três categorias apontadas por ele:

I. Relíquias ou restos, que são vestígios do passado sem qualquer propósito de conservar ou transmitir à posteridade a memória do presente, como edifícios, armamentos, brasões, contratos, leis, cartas, festas, etc.

II. Monumentos erigidos com o propósito de conservar para a posteridade a memória do presente, como por exemplo construções de monumentos, túmulos, inscrições, etc.

III. Tradição oral e escrita 26 .

Percebe-se na enumeração de Loria a noção de que os conhecimentos matemáticos de certo modo precederam a capacidade humana de escrever suas idéias, existindo muitos testemunhos da Matemática do passado em forma por exemplo de obras arquitetônicas. Inclusive também, segundo Marrou, pode-se considerar como documento histórico toda fonte da qual o espírito do historiador saiba extrair informações para o conhecimento do passado humano, de acordo com seu objetivo ${ }^{27}$. Mas é evidente que só com o surgimento da escrita é que se passou a registrar com maior fidedignidade o estágio matemático de uma determinada cultura. Desse modo, a maior parte das informações nos vem do período posterior ao surgimento da escrita, por volta de cinco mil anos antes de Cristo, e principalmente após a constituição da Matemática enquanto Ciência e sua primeira organização lógica, feito que provavelmente se deve aos gregos do século VI a.C.

Portanto, como se verá, esse trabalho lida fundamentalmente com fontes do tipo literário, embora também para esses documentos seja aplicável o que foi dito acima, acerca do valor do recurso às fontes, pois é a própria produção escrita dos matemáticos que fornece rico material para a pesquisa em História da Matemática. Javier de Lorenzo, em sua Introducción al Estilo Matematico ${ }^{28}$, caracteriza essas diferentes formas de expressão utilizadas pelos matemáticos em três distintos níveis:

\title{
Linguagem de criação \\ Linguagem de exposição \\ Linguagem de divulgação 29
}

Explica que a linguagem de criação pode ser encontrada em trechos de diários, cartas, ensaios breves, etc, muitas vezes em esquemas pouco claros e incompletos ${ }^{30}$. Já para expor suas idéias, o matemático cuida mais da forma e do rigor da

\footnotetext{
23 LORIA, Gino. Guida allo Studio del/ ${ }^{\mathrm{a}}$ Storia delle Matematiche. $2^{\mathrm{a}}$ ed. Milano, Ulrico Hoepli, 1946. 385 p. Principalmente o Capitolo II: Rassegna delle principali opere sulla Storia delle Matematiche, pp. 15-60

24 Ibid., p. 15

25 Cf. MARROU, op. cit., p. 60

26 LORIA, op. cit., p. 4

27 Cf. MARROU, op. cit., p. 62

28 LORENZO, Javier de. Introducción al Estilo Matematico. Madrid, Tecnos, 1989. 209 p.

29 lbid., p. 196

30 Cf., p. ex., EULER, Leonhard. Cartas a uma Princesa de Alemania sobre Diversos Temas de Física e Filosofía. Ed. de Carlos Mínguez Péres. Zaragoza, Universidad de Zaragoza, 1990. 613 p.
} 
linguagem. Para fazer a divulgação, muitas vezes em obras ou publicações de cunho didático, o autor procura atingir um público mais amplo, através de uma linguagem acessível.

Antes que os matemáticos começassem a produzir, havia outros tipos de registros da Matemática de cada época, que também servem de fonte da História da Matemática. Dedicaremos à consideração desses documentos e seus caminhos até nós no item Caminhos da História da Matemática Pré-Helênica. Estudaremos o surgimento de obras propriamente matemáticas que se deu com o advento da civilização grega no item Tradição Greco-Latina. A conservação e transmissão da ciência e cultura gregas durante a segunda metade do primeiro milênio da nossa era será estudada no item De Boécio a Gerbert. O período seguinte, caracterizado pelo surgimento das Universidades européias e o crescente interesse pela Ciência que provocou um retorno aos originais gregos via traduções para o latim, será estudado no item O Renascimento no Século XII. Encerramos essa primeira capítulo com um estudo sobre a época marcada pela utilização da imprensa e o surgimento de muitas obras especificamente sobre História da Matemática, até as atuais obras disponíveis nas bibliotecas, no item O Advento dos Livros de História da Matemática. Esses livros, em sua divisão por tipos, serão estudados com maior pormenor no segundo capítulo desse trabalho. 


\title{
1.2 Caminhos da História da Matemática Pré-Helênica
}

\author{
Os documentos preservados não \\ são sempre (a experiência quase nos autoriza a \\ escrever: nunca) aqueles que desejaríamos, que \\ seria preciso que fossem. Ou não existem, ou são \\ em número insuficiente: é o que comumente \\ ocorre em história antiga.
}

Marrou $^{31}$

O legado científico e cultural que a Civilização greco-romana nos deixou talvez seja responsável pela concepção usual de que a História deve ser registrada e preservada para as gerações futuras. Mas antes de Heródoto, considerado por alguns pelo seu pioneirismo como o Pai da História, essa concepção não era nada corrente. Desse modo, os historiadores têm dificuldades especiais para construir a História Antiga da Matemática, principalmente do período anterior aos gregos. Conforme explica Marrou, em história antiga,

na maioria das vezes, trabalhamos sobre fontes literárias, sempre concisas demais, e, de resto, secundárias ou terciárias (...); as poucas fontes primárias que possuímos estão representadas pelos documentos arqueológicos, as inscrições, os papiros descobertos ao sabor das escavações, em virtude, portanto, de uma seleção arbitrária ${ }^{32}$.

Mesmo com a espantosa duração de Civilizações como a do Egito, mais do que o dobro de toda a era cristã, a quantidade de registros intencionalmente históricos é ínfima, se comparada com a nossa. Basta ver que quando um faraó sucedia a outro no trono, muitas vezes fazia por apagar, literalmente, o nome do antecessor de todas as inscrições nos templos e palácios, na tentativa de eternizar seu próprio nome como o autor daquelas obras. No que se refere à Matemática existem, no entanto, registros que se conservaram até hoje. Por aterem-se excessivamente às necessidades práticas, os egípcios não arriscavam alçar vôos rumo às generalizações. Cada problema era resolvido de um modo particular, não havendo na verdade métodos gerais de resolução de problemas ${ }^{33}$. O que faziam era registrar a resolução de cada problema passo por passo, e é graças a isso que podemos conhecer agora como era a Matemática da época. A História da Matemática egípcia é tarefa de pesquisadores atuais, que baseados em dados arqueológicos procuram reconstituir o que quer que se assemelhe a Matemática e que se conservou até hoje.

De fato, o conhecimento da Matemática egípcia nos chegou apenas após os hieróglifos terem sido decifrados por Champollion, que publicou em 1842 seu Dictionnaire Egyptien ${ }^{34}$. A Pedra de Rosetta, trazendo a inscrição trilingüe que lhe permitiu a decifração dos hieróglifos, foi produzida em 196 aC e permaneceu incógnita por muitos séculos ${ }^{35}$. O mais famoso papiro egípcio sobre Matemática foi produzido pelo escriba Ahmes ${ }^{36}$ em 1650 aC e encontrado mais de 3000 anos depois, quando em 1858 o antiquário escocês Henry Rhind o adquiriu ${ }^{37}$. Somente em 1877 é que Eisenlohr conseguiu traduzi-lo38. Não há, portanto, uma tradição linear ligando a nossa Civilização à do Egito Antigo, e a pesquisa sobre sua Matemática tem que ser feita com base nesses achados arqueológicos.

Algo semelhante se dá com a Matemática dos povos da Mesopotâmia. Existem centenas de tabletas cuneiformes trazendo informação sobre a Matemática de

31 MARROU, Henri-Irénée. Sobre o Conhecimento Histórico. Tradução de Roberto Cortes de Lacerda. Rio de Janeiro, Zahar Editores, 1978, 265 p., p. 56

32 Id., ibid.

33 Cf. BOYER, Carl Benjamin. História da Matemática. Tradução de Elza F. Gomide. São Paulo, Edgard Blücher, 1974. 488 p., p. 16

34 Cf. GILLINGS, Richard J. Mathematics in the Time of the Pharaohs. New York, Dover, 1972. 288 p. 1

35 Cf. CERAM, C. W. Deuses, Túmulo e Sábios: o Romance da Arqueologia. Trad. de João Távora. $16^{\mathrm{a}}$ ed. São Paulo, Melhoramentos, 1982. 392 p., p. 79

36 Cf., p. ex., a tradução de Thomas Eric Peet: The Rhind Mathematical Papirus. Apud MIDONICK, Henrietta O. (Ed.) The Treasury of Mathematics. New York, Philosofical Library, 1965. 820 p., pp. 706-32

37 Cf. BOYER, op. cit., p. 9

38 Cf. CAJORI, Florian. A History of Mathematics. $2^{\mathrm{a}}$ ed. New York, The MacMillan Company, 1919, 516 p., p. 9 
quatro mil anos atrás. A tradução desse material só teve início em 1870, quando se descobriu uma inscrição também trilingüe nas encostas do monte Behistun, narrando a vitória do rei Dario sobre Cambises ${ }^{39}$. Somente em 1934 Otto Neugebauer decifrou, interpretou e publicou as tabletas matemáticas babilônias ${ }^{40}$.

Do mesmo modo, uma pessoa que queira conhecer a História da Matemática da China, da Índia ou do Japão deve recorrer aos originais antigos que de algum modo se preservaram até hoje e a partir dos quais são inclusive escritas obras de História da Matemática dessas civilizações, como The Development of Mathematics in China and Japan, de Yoshio Mikami ${ }^{41}$, e a incomparável obra em três volumes de Joseph Needham, Science and Civilization in China ${ }^{42}$. Existem muitas dificuldades inclusive para saber a data de documentos antigos, pois as obras chinesas podem ter vários autores de épocas diferentes ${ }^{43}$, enquanto algumas obras hindus apresentam datação considerada inverossímil, como dois milhões de anos ${ }^{44}$.

Outra fonte sobre a História da Matemática primitiva, sobretudo a respeito do surgimento dos números, é o estudo das linguagens indígenas, que muitas vezes remontam a épocas pré-históricas 45 , e o estudo das formação das palavras das línguas modernas.

Essa ausência de tradição linear que liga a Matemática das civilizações pré-helênicas até hoje pode ser um dos fatores que reforçam a idéia de que a Matemática é uma ciência que praticamente nasceu pronta. Essa idéia está muito presente em algumas concepções do ensino da Matemática, principalmente no nível elementar. A sistematização grega da Matemática é muitas vezes identificada como sua própria gênese, e poucos autores retrocedem para antes dos gregos ao estudar a História da Matemática. Piaget e Garcia, por exemplo, ao elaborarem sua obra Psicogênese e História das Ciências ${ }^{46}$, iniciam o estudo histórico a partir dos gregos, justificando-se precisamente pela falta de uma ligação para com a evolução anterior aos gregos.

39 Cf. BOYER, op. cit., p. 8

40 Cf. NEUGEBAUER, Otto. Mathematische Keilschrigt Texte. Berlin, Springer-Verlag, 1934.

41 MIKAMI, Yoshio. The Development of Mathematics in China and Japan. New York, Chealsea, 1913, $347 \mathrm{p}$.

42 NEEDHAM, Joseph. Science and Civilization in China. Cambridge, University Press, 1959. 3 v.

43 Cf. BOYER, op. cit., p. 143

44 Cf. BOYER, op. cit., p. 152

45 Cf. GROZA, Vivian Shaw. A Survey of Mathematical Elementary Concepts and their Historical Development. New York, Holt, Rinehart and Winston, 1968. 327 p., p. 8

46 PIAGET, Jean \& GARCIA, Rolando. Psicogênese e História das Ciências. Lisboa, Publicaç/Ees Dom Quixote, 1987. 247 p., p. 88 


\subsection{A Tradição Greco-Latina}

Todo os homens têm, por natureza, desejo de

conhecer.

Aristóteles 47

Com o advento da Civilização grega tem início uma preocupação especial com a História, e conseqüentemente com a História da Matemática. As mais antigas Histórias da Matemática são gregas e a primeira de que se tem notícia foi escrita por Eudemos de Rodes ${ }^{48}$, por volta de 320 aC. Eudemos era um peripatético, isto é, aluno de Aristóteles. Essa obra histórica de valor inestimável não sobreviveu à passagem dos anos. Nela certamente haveria muitos dados sobre a controvertida passagem das Matemáticas Pré-Helênicas, de caráter eminentemente prático, para os sistema mais teórico dos gregos. O papel de Tales de Mileto (624-548 aC) e de Pitágoras de Samos (580-500 aC) nessa construção inicial do pensamento matemático na Grécia também seria melhor elucidado. Mas desse livro de Eudemos só nos restam referências esparsas em outras obras. O mesmo pode-se dizer da Biografia de Pitágoras, escrita pelo próprio Aristóteles ${ }^{49}$, que também se perdeu.

Outros livros que foram preservados dessa época trazem algumas referências ao início heróico da Matemática grega, mesmo não sendo livros propriamente de História da Matemática. Por exemplo, a maior parte dos trabalhos de Platão e cerca de metade dos de Aristóteles se conservou até hoje ${ }^{50}$, e esses filósofos possuíam um real interesse pela totalidade do Conhecimento de uma maneira ampla, incluindo a Matemática. Mas o que mais se aproxima de uma narrativa verdadeiramente histórica da evolução da Matemática nesse período, e que se conservou, encontra-se num Comentário ao primeiro livro de Os Elementos de Euclides, escrito pelo filósofo neo-platônico Proclus Diadochus $(410-485 \mathrm{dC})^{51}$. Apesar do milênio que o separa da vida de Tales, é em Proclus que nos baseamos para afirmar quase tudo o que sabemos sobre Tales e Pitágoras, porque teria incorporado no seu Comentário um trecho resumido da História da Matemática de Eudemos.

Logo no início do Comentário, por exemplo, após reafirmar a idéia de ter a Geometria tido seus primórdios no Egito, diz que Tales

primeiro foi ao Egito e de lá introduziu este estudo na Grécia. Descobriu muitas proposições ele próprio, e instruiu seus sucessores nos princípios que regem muitas outras, seu método de ataque sendo em certos casos mais geral, em outros mais empírico ${ }^{52}$.

Depois, prossegue dizendo que

Pitágoras, que veio após ele, transformou esta Ciência em uma forma liberal de educação, examinando seus princípios a partir do início e provando os teoremas de uma forma imaterial e intelectual. Ele descobriu a teoria dos proporcionais e a construção das figuras cósmicas ${ }^{53}$.

Uma coleção de Biografias de Matemáticos e Filósofos Gregos é atribuída

a Diógenes Laércio ${ }^{54}$. Nessa obra se encontra, por exemplo, a narração de que Tales mediu a altura das pirâmides do Egito observando o comprimento das suas sombras no momento em que a sombra de um bastão vertical era igual à sua altura.

Além desses documentos específicos de História, para se reconstituir o período grego contamos com inúmeros escritos propriamente matemáticos, muitos deles

\footnotetext{
47 ARISTÓTELES. Metafísica. A. 1. Apud: Coleção "Os Pensadores". V. IV. $1^{\mathrm{a}}$ ed. Trad. de Vicenzo Cocco. São Paulo, Abril Cultural, 1973. p. 211

48 Cf. LORIA, Gino. Guida allo Studio della Storia delle Matematiche. $2^{\mathrm{a}}$ ed. Milano, Ulrico Hoepli, 1946. 385 p., p. 16

49 Cf. BOYER, Carl Benjamin. História da Matemática. Tradução de Elza F. Gomide. São Paulo, Edgard Blucher, 1974,488 p. 72

50 Cf. Ibid., p. 61

51 Cf., p. ex., a trad. de Ivor Thomas. Proclus Summary. Apud: MIDONICK, Henrietta O. (Ed.) The Treasury of Mathematics. New York, Philosofical Library, 1965. 820 p.

52 Cit. in. HEATH, Thomas Litle. A History of Greek Mathematics. New York, Dover, 1981. 2 v. I, p. 128. Cf. BOYER, op. cit., p. 35

53 Cit. in HEATH, op. cit., p. 141. Cf. BOYER, op. cit., p. 36

54 Cf. LORIA, op. cit., p. 16
} 
estruturados já segundo um nível lógico formalizado, como é o caso de Os Elementos de Euclides ${ }^{55}$. Falaremos sobre a importância dessa organização lógica dos gregos no Capítulo 3 desse trabalho. Por hora basta dizer que a Matemática atual apresenta características lógicas que se podem chamar herdadas dos gregos. Paralelamente a essa herança de conhecimentos especificamente matemáticos, existe uma linha de transmissão do conhecimento sobre a História da Matemática começando na Grécia, no século $\mathrm{VI} a \mathrm{aC}$, e prosseguindo até o surgimento das Universidades na Europa no século doze, que podemos chamar de Tradição Greco-Romana ou Greco-Latina.

É claro que, dentro desse milênio e meio, outros povos e outras línguas de modo especial, os árabes -, tiveram uma participação importante na História da Matemática. Principalmente porque a passagem natural da Ciência grega através do mundo romano viu-se interrompida com a invasão dos bárbaros que tomaram Roma em 476. Quando, a partir do segundo milênio da nossa era, o surgimento das Universidades na Europa começar a atrair o interesse dos estudiosos latinos para os textos gregos, é em grande parte a língua árabe que vai servir como ponte de ligação entre o grego e o latim.

Os árabes, desde o início da era maometana em 622, foram conquistando paulatinamente muitos dos centros culturais da Antiguidade, como Alexandria, em 641. No século oito, funda-se a Casa da Sabedoria em Bagdá, no final do califado de Harum alRaschid (786-809), famoso por figurar nas Mil e uma Noites. Bagdá torna-se então um grande centro cultural, onde se farão traduções de inúmeras obras gregas, as quais mais tarde foram por sua vez traduzidas para o latim.

Parece muito provável que, em meio aos 750.000 volumes que supostamente continha a Biblioteca de Alexandria, haveria informação abundante sobre História da Matemática. Entretanto, entre o incêndio provocado por Júlio César no ano 47 $\mathrm{aC}$, em perseguição a Pompeu que se refugiara em Alexandria, e a queima quase total de $641 \mathrm{dC}$, decretada pelo Califa Omar, sucessor de Maomé no comando dos árabes, pouco sobrou para contar essa valiosa História. É importante observar que parte desse tesouro da Tradição Greco-Latina conseguiu sobreviver ao fogo cruzado das invasões árabes por um lado e dos ataques bárbaros por outro.

Pode não ser verdadeiro o relato de que os árabes, após terem tomado Alexandria, decidiram queimar os livros da Biblioteca pois se estivessem de acordo com o Corão, seriam supérfluos, e se estivessem em desacordo, seriam pior que supérfluos ${ }^{56}$. Nem que as fogueiras dos acampamentos árabes foram alimentadas durante meses com os milhares de volumes da Biblioteca, pois de certo modo essa atitude estaria em contradição com o espírito freqüentemente árabe de apropriar-se da cultura do povo conquistado, fazendo dela uso prático, e contribuindo assim indiretamente para a preservação do conhecimento para as gerações posteriores. Mas se escapou aos prováveis incendiários árabes, certamente a Cultura Greco-Latina, incluindo informações valiosas sobre História da Matemática, teve muito que padecer nas mãos dos povos bárbaros.

Os bárbaros paulatinamente penetraram por todos os lados do decadente Império Romano, durante os primeiros séculos da nossa era: vândalos, visigodos, ostrogodos, etc. E sua presença causou uma desconexão com as sutilezas filosóficas do espírito grego, conforme descreve Collette:

Quando as grandes invasões deslocaram o Império Romano do Ocidente e instalaram um rei ostrogodo no lugar do Imperador, - Ocidente ficou praticamente desconectado do Império Romano do Oriente e, por esse mesmo fato, desligado da Ciência helênica. Só subsistiram as tradições transmitidas em latim por autores que viveram durante os séculos $\mathrm{V}$ e $\mathrm{VI}^{57}$.

Falaremos a seguir sobre esses autores que transmitiram a Tradição Greco-Latina, a partir dos séculos V e VI.

\footnotetext{
55 Cf., p. ex., a trad. comentada de Thomas Little Heath. The Thirteen Books of Euclid's Elements. $2^{\mathrm{a}}$ ed. New York, Dover, 1956. 3 v.

56 Cf. BOYER, op. cit., p. 165

57 COLLETTE, Jean-Paul. Historia de las Matemáticas. Traducción de Pilar González Gayoso. Mexico, Siglo Veintiuno, 1986, 2 v. V. I, p. 218
} 


\subsection{De Boécio a Gerbert}

Deve-se ensinar divertindo. Alcuino 58

Tornando-se Odoacro, o Hérulo, Imperador romano em 476, já ocorre uma grande alteração nos cuidados oficiais com a Cultura. Seu sucessor Teodorico, 0 Ostrogodo, ainda mantém-se por algum tempo assessorado por um dos últimos Senadores Romanos, Ancius Manílius Torquatus Severinus Boethius, ou Boécio, que viveu de 480 a 524. Boécio será, na corte bárbara, como que um representante da Cultura e Ciência Helênicas, pois é

não apenas um filósofo e matemático, mas também um homem de Estado $^{59}$, um romano que conhece a fundo a cultura grega e que percebe que o esplendor cultural do mundo antigo passou(...). No entanto, percebe o que deve ser feito: só se pode salvar a cultura em épocas de crise como a que ele viveu adaptando-se às condições dos bárbaros 60 .

Conforme relata Cajori61, o trabalho de Boécio não foi em vão. Apesar de que parte do seu projeto fosse traduzir todas as obras de Platão e Aristóteles ${ }^{62}$, Boécio não pode completá-lo: teve um fim trágico e repentino. Por ter desagradado Teodorico, foi aprisionado e executado algum tempo depois ${ }^{63}$. Uma possível explicação desse desagrado é aventada por Boyer64. Boécio, que era cristão assim como outros matemáticos (Pappus, por exemplo), teria adotado idéias sobre a Trindade Divina que estariam em desacordo com as crenças do Imperador. Mesmo na prisão, o esforço intelectual de Boécio não cessou, e foi lá que ele escreveu sua obra mais célebre, De Consolatione Philosophiae. Nesse ensaio em prosa e verso, discute a responsabilidade moral à luz da filosofia aristotélica e platônica ${ }^{65}$.

Devido ao esforço de pessoas como Boécio, tornou-se possível a sobrevivência da Matemática na Europa Ocidental, pois

graças a esse trabalho humilde e sacrificado, assumido conscientemente por quem tinha talento para muito mais, a Matemática preservou-se no Ocidente e pôde manter-se até o século $X$, quando recebe novo impulso com Gerberto e, a partir dos séculos seguintes, desenvolver-se mais e mais 66 .

De fato, até finais do século $X$, outros autores latinos como Cassiodoro, Isidoro de Sevilha, Beda o Venerável e Alcuíno irão exercer grande influência sobre o ensino da Matemática nas escolas medievais, servindo-se principalmente de trabalhos de Euclides, Nicômaco e Ptolomeu67. Após o século $X$, terá início um movimento de maior retorno à Ciência grega, valendo-se do auxílio de versões manuscritas árabes.

Enquanto os povos bárbaros se estabelecem na Europa, vão pouco a pouco assimilando essa Cultura Greco-Romana, até chegarem a formar as atuais nações européias (França, Alemanha, Inglaterra, etc). Para que tal processo ocorresse, tiveram importante papel as instituições monásticas de ensino, pois havia praticamente uma escola para cada mosteiro, e era lá que o ensino pode sobreviver ao descaso bárbaro, principalmente durante o período de 500 a $1200^{68}$. Além desse papel de divulgação, os monges medievais contribuíram muito para a preservação da Cultura em si, através das

58 Cf. LAUAND, Luiz Jean. Educação, Teatro e Matemática Medievais. São Paulo, Perspectiva/EDUSP, 1986, 117 p., p. 73

59 BOYER, Carl Benjamin. História da Matemática. Trad. de Elza F. Gomide. São Paulo, Edgard Blucher, 1974, 488 p., p. 139

60 LAUAND, op. cit., p. 23

61 Cf. CAJORI, Florian. A History of Mathematics. New York, The Macmillan Company, 1919, 516 p., p. 67

62 Cf. LAUAND, op. cit., p. 24

63 Cf. BOYER, op. cit., p. 140

64 Id., ibid.

65 Id., ibid.

66 LAUAND, op. cit., p. 25

67 Cf. COLLETTE, Jean-Paul. Historia de las Matemáticas. Mexico, Siglo Veintiuno, 1986, 2 v. V. I, p. 219

68 Cf. ARCHIBALD, Raymond Clare. Outline on the History of Mathematics. Ohio, Mathematical Association of America, 1941,76 p., p. 26 
cópias manuscritas que realizavam com tal dedicação que cada página era uma verdadeira obra de arte 69 .

Dos mosteiros sairão as maiores obras com informações sobre a História da Matemática desse período. Cassiodoro (480-575), discípulo de Boécio, escreveu diversas obras matemáticas que serviam de livro-texto nas escolas dos mosteiros ${ }^{70}$. Cassiodoro morreu em idade avançada num convento que ele mesmo havia fundado, tendo incentivado grandemente

aos monges a cópia de manuscritos, costume que persistiria durante muito tempo nos conventos do período medieval e teve desta forma uma importante influência nas tradições científicas ${ }^{71}$.

Depois dele, outro autor produtivo foi Santo Isidoro de Sevilha (570-636), que escreveu uma Enciclopédia em 20 volumes intitulada Origens ou Etimologias ${ }^{72}$. Conforme comenta Cajori 73 , essa obra segue o modelo das enciclopédias romanas de Martianus Capella de Cartago e Cassiodoro. Parte dela é dedicada ao estudo da Matemática, dentro da concepção corrente na época, que englobava o chamado Quadrivium - Aritmética, Música, Geometria e Astronomia. Essa parte da Enciclopédia é de especial importância para a História da Matemática, pois contém já os numerais indo-arábicos que serão mais tarde os substitutos dos algarismos romanos ${ }^{74}$.

Outra fonte de informação sobre a História da Matemática são os trabalhos do monge inglês São Beda, o Venerável (673-735). É interessante observar que muitas das suas 37 obras são tratados sobre o cálculo necessário para a datação precisa da Páscoa, base do Calendário. Inclusive comenta Cajori que mesmo o cálculo do Calendário contribuiu para que a arte de calcular sempre encontrasse algum lugar no currículo para a educação dos monges ${ }^{75}$. Segundo Smith, São Beda pode ser considerado um precursor do ensino na Inglaterra, e por isso suas obras adquirem uma importância singular 76 .

É outro inglês o responsável principal pelo desenvolvimento da Educação no Grande Império Franco: Alcuíno de York (735-804). Ele nasceu no ano da morte de São Beda, e após ter sido educado na Irlanda tornou-se o maior colaborador de Carlos Magno, que tinha muita preocupação com o ensino ${ }^{77}$. O trabalho de Alcuíno na França foi o estopim do chamado Renascimento Carolíngeo, nas Artes, na Ciências e no Ensino. Uma de suas mais importantes obras é precisamente de natureza didática. Trata-se do Diálogo entre Pepino e Alcuíno ${ }^{78}$, em que são recolhidos inúmeros enigmas e adivinhações com funções pedagógicas, bem de acordo com suas idéias no campo educativo, que incluíam seu famoso princípio citado na epígrafe deste item:

\section{Deve-se ensinar divertindo ${ }^{79}$.}

Também é atribuída a Alcuíno a autoria de uma coletânea de problemas que segundo ele eram apropriados ao desenvolvimento da inteligência dos jovens ${ }^{80}$, que constituem uma boa amostra não só da Matemática desse período, como também do seu interesse pela Educação. O modo como Alcuíno procurava ensinar a Matemática - através da resolução de problemas ${ }^{81}$ - possui importância particularmente atual, já que essa técnica tem

69 Cf. NUNES, Rui Afonso da Costa. História da Educação. São Paulo, EPU/EDUSP, 1978-81. 4 v.

70 Cf. BOYER, op. cit., p. 181

71 COLLETTE, op. cit., p. 221

72 San Isidoro de Sevilha. Etimologías. Versão bilingue (Latim/ Espanhol) de José Oroz Reta e Manuel-A. Marcos Casquero. Madrid, Biblioteca de Autores Cristianos, 1982. Livro III (De Mathematica), p. 422 a 481

73 Cf. CAJORI, op. cit., p. 113

74 Cf. BOYER, op. cit., p. 182

75 Cf. CAJORI, op. cit., p. 114

76 Cf. SMITH, op. cit., p. 184

77 Cf. CAJORI, op. cit., p. 114

78 Cf. LAUAND, op. cit., p. 71

79 LAUAND, op. cit., p. 73

80 Cf. CAJORI, op. cit., p. 114

81 Alguns desses problemas aparecem em EVES, Howard. An Introduction to the History of Mathematics. New York, Holt, Rinehart and Winston, 1969, 464 p., p. 227 
recentemente sido objeto de interessantes estudos relacionados com a didática da Matemática 82 .

Além dos manuscritos latinos, um dos caminhos percorridos pela História da Matemática da Antigüidade até nós foi o dos manuscritos árabes. O recurso a esses manuscritos deveu-se fundamentalmente ao fato de o interesse pelos textos matemáticos crescer muito na Europa, de modo que apenas o que fora resgatado por Boécio e outros tornou-se insuficiente.

Nesse recurso aos árabes, terá influência decisiva um monge francês de extraordinária atividade científica: Gerbert ou Gerberto (950-1003). Conforme explica Cajori, o zelo com o qual o estudo da Matemática foi tomado pelos monges é devido principalmente à energia e influência de Gerbert ${ }^{83}$. Tanto assim que, no século $X$, pode-se dizer que recomeça o progresso da Matemática, já que as obras de Gerbert corrigem muitos erros dos séculos anteriores ${ }^{84}$. Ao lado dos muitos trabalhos matemáticos que produziu, dedicou-se também a diversos outros campos de atividade. Conforme relatam os historiadores, Gerbert nasceu em Auvergne, França, possuindo dons incomuns para a Matemática e outras ciências. Chegou a construir ábacos, globos terrestres e celestes, um relógio, e talvez até um órgão ${ }^{85}$, escrevendo também sobre Aritmética, Geometria e outras áreas da Matemática, e provavelmente sobre o Astrolábio ${ }^{86}$. Sendo um dos primeiros cristãos a estudar nas escolas árabes da Espanha ${ }^{87}$, Gerbert adquiriu logo fama de sábio e educador. Foi então chamado a ser tutor e conselheiro de Otto III, Imperador do Santo Império Romano. Mais tarde tornou-se Arcebispo, primeiro em Reims e depois em Ravenna, e em 999 foi elevado ao papado, com o nome de Silvestre $\|^{88}$. Com relação a sua contribuição para o desenvolvimento da Matemática, relata Lattin:

Com Gerbert, a atividade numérica prática (Logística) pela primeira vez obteve o mesmo "status" da atividade numérica teórica (Aritmética) como matéria de ensino avançado formal. Ele desenvolveu velocidade nas operações aritméticas através da revitalização do uso do ábaco e sua introdução, a partir da Espanha, dos nove numerais indoarábicos (sem o zero). Além disso, trouxe consigo regras para sua utilização, que escreveu de forma elaborada 89 .

Os abundantes escritos de Gerbert fornecem uma panorâmica acerca dos métodos de calcular da Europa antes da introdução dos numerais indo-arábicos ${ }^{90}$. Mas é sem dúvida seu papel de educador, ao lado da introdução, difusão e ensino dos numerais indo-arábicos, que constitui sua mais interessante contribuição, dando-lhe um lugar especial na História da Matemática ${ }^{91}$. Quando faleceu, a 12 de maio de 1003, já havia infundido nova vida no estudo não apenas da Matemática, mas também da Filosofia ${ }^{92}$. Segundo Lattin,

as porções remanescentes do corpo lógico aristotélico que tornaram-se parte do pensamento europeu ocidental no século XII foram integrados num único tecido apenas sobre o sólido fundamento do ensino organizado por Gerbert no século $X^{93}$.

Seus inúmeros alunos, da França, da Alemanha ou da Itália, tornaram-se por sua vez professores e difundiram esse conhecimento pela Europa ${ }^{94}$, promovendo 0

82 Cf., p. ex., DINIZ, Maria Ignez de Souza Vieira (et al.). A Resolução de Problemas. Capítulo 1 da Proposta Curricular de Matemática para o CEFAM e Habilitação Específica para o Magistério. Vários autores. São Paulo, Secretaria de Educação/Coordenadoria de Estudos e Normas Pedagógicas, 1990. 257p., pp. 15-25

83 Cf. CAJORI, op. cit., p. 115

84 Cf. LAUAND, op. cit., p. 96

85 Cf. EVES, op. cit., p. 207

86 Cf. SMITH, David Eugene. History of Mathematics. 2 v. Boston, Ginn and Co., 1923. V. I, 596 p., p. 196

87 Cf. EVES, op. cit., p. 207

88 Cf. BOYER, op. cit., p. 182

89 LATTIN, Harriet Pratt (Ed.). The Letters of Gerbert. New York, Columbia University Press, 1961. 412 p., p. 19

90 Cf. CAJORI, op. cit., p. 115

91 Cf. BOYER, op. cit., p. 182

92 Cf. CAJORI, op. cit., p. 118

93 LATTIN, op. cit., p. 20

94 Cf. CAJORI, op. cit., p. 118 
interesse pelos clássicos gregos sobre Ciência e Matemática ${ }^{95}$. Esse interesse irá desencadear uma nova etapa muito importante para a História da Matemática, que estudaremos a seguir.

95 Cf. EVES, op. cit., p. 208 


\subsection{O Renascimento no Século XII}

Em 1136, ainda adolescente, John de Salisbury estudou lógica em Paris e ficou muito impressionado com os mestres e as aulas brilhantes a que assistiu.

Kneale \& Kneale 96

Para compreender o caminho da História da Matemática até hoje é necessário observar o que se passou na Europa no século XII. Boyer diz que a barreira entre os europeus e a cultura árabe foi superada nesse século. Ao redor do ano 1000, os matemáticos ou astrônomos europeus tinham que possuir um bom conhecimento da língua árabe para aprofundar nos estudos. Mas já no fim do século pode surgir na Itália cristã um matemático do peso de Fibonacci. Boyer prossegue dizendo que:

A época foi tão evidentemente de transição de um ponto de vista mais antigo para um mais novo que $\mathrm{C}$. H. Haskins denominou sua obra The Renaissance of the Twelfth Century (New York, Meridian Books, 1957). O ressurgimento que ele descreveu começou, inevitavelmente, com uma série de traduções ${ }^{97}$.

Uma das primeiras obras matemáticas clássicas a aparecer em tradução latina do árabe foram Os Elementos de Euclides, a versão tendo sido feita em 1142 por Adelard de Bath (cerca de 1075-1160). Eves relata que Adelard teria corrido riscos físicos na sua busca do conhecimento árabe, disfarçando-se inclusive de estudante maometano98. $\mathrm{E}$ Cajori acrescenta que, no primeiro quarto do século XII, Adelard teria viajado pela Ásia menor, Egito, talvez também pela Espanha, enfrentando grandes perigos 99 . Sem dúvida, Adelard teve dificuldades para realizar suas traduções, pois estava na linha de frente, entre os primeiros estudiosos dedicados à tradução de manuscritos para o latim. Mas logo suas traduções tornaram-se algo bastante comum na Europa. Na Espanha, especialmente em Toledo, onde o arcebispo encorajava tal trabalho, uma verdadeira escola de tradução se desenvolvia. Conforme explica Boyer,

a cidade, outrora uma capital visigoda, mais tarde esteve nas mãos dos mouros por vários séculos, antes de ser conquistada pelos cristãos, e era um lugar ideal para a transmissão da cultura. Nas bibliotecas de Toledo havia uma quantidade de manuscritos muçulmanos; e grande parte da população, composta de cristãos, maometanos e judeus, falava o árabe, 0 que facilitava o fluxo interlíngue de informação ${ }^{100}$.

Dentre os tradutores da Espanha destaca-se Gerardo de Cremona (11141187). Em 1175 Gerardo traduziu o Almagesto de Ptolomeu, obra muito importante do ponto de vista histórico. Entre as mais de oitenta e cinco obras atribuídas a Gerardo encontra-se uma adaptação em latim da Al-jabr wa'l Muqabalah de al-Khowarismi101, de cujo título advém nosso termo Álgebra ${ }^{102}$. Desse modo a Ciência Antiga pode ser recuperada plenamente e preservada para as pesquisas dos séculos futuros. Obras de Filosofia e Lógica também foram sendo recuperadas. Como dizem Kneale e Kneale,

pouco depois de 1250 o conjunto do Organon estava em circulação, ou na antiga versão de Boécio ou em traduções recentes e dentro dos 50 anos seguintes os restantes escritos de Aristóteles foram traduzidas para 0

\footnotetext{
96 KNEALE, Willian \& KNEALE, Martha. O Desenvolvimento da Lógica. $1^{\mathrm{a}}$ ed. Trad. de M. S. Lourenço. Lisboa, Fundação Calouste Gulberkian, 1972, 770 p., p. 231

97 BOYER, Carl Benjamin. História da Matemática. Tradução de Elza F. Gomide. São Paulo, Edgard Blücher, 1974, 488 p., p. 183

98 Cf. EVES, Howard. An Introduction to the History of Mathematics. New York, Holt, Rinehart and Winston, 1969, 464 p., p. 208

99 Cf. CAJORI, Florian. A History of Mathematics. $2^{\mathrm{a}}$ ed. New York, The MacMillan Company, 1919, 516 p., p. 118

100 BOYER, p. 183

101 lbid., p. 184

102 Pelo fato de álgebra significar originalmente "restauração", o termo álgebrista foi usado também para designar o médico que restaurava ossos partidos. Assim temos, no clássico espanhol Dom Quixote:...até que chegaram a um povo, onde felizmente encontraram um algebrista, que tratou o desgraçado Sansão, o qual havia fraturado a perna ao cair do cavalo, em duelo com Dom Quixote. Cf. CERVANTES, Miguel de. O Engenhoso Fidalgo Dom Quixote de la Mancha. Tradução de Viscondes de Castilho e Azevedo. São Paulo, Abril Cultural, 1978. 609 p., p. 369
} 
Latim. Algumas traduções foram feitas nesta altura em Espanha a partir de traduções Arábicas; outras foram feitas em Itália por estudiosos em contato com a cultura Bizantina ${ }^{103}$.

Após o século XII, com o surgimento das Universidades Européias, tem início o período dentro do qual encontramos os livros específicos de História da Matemática, de início manuscritos, mas logo impressos tais como podem ser hoje encontrados nas bibliotecas. No século XIII, as Universidades começaram a florescer em Bolonha, Pádua, Nápoles, Paris, Oxford e Cambridge. Pessoas que fizessem reproduções manuscritas de tratados eram intensivamente empregados pelas universidades, e pela metade do século XV, seus produtos estavam sendo vendidos como os livros de hoje em dia. Tais métodos de difundir conhecimento foram aperfeiçoados em muito quando se deu início à distribuição de obras impressas. Conforme relata Archibald,

a publicação destas, com tipos móveis, começou por volta de 1450 . Mais de duzentas obras matemáticas foram impressas, apenas na Itália, antes de 1500; mas esse número foi aumentado para 1527 no século seguinte ${ }^{104}$.

Passaremos a falar agora desses livros que começaram a ser impressos, dentre os quais havia alguns especificamente de História da Matemática.

103 KNEALE, op. cit., p. 230

104 ARCHIBALD, Raymond Clare. Outline on the History of Mathematics. Ohio, Mathematical Association of America, 1941,76 p., p. 26 


\title{
1.6 O Advento dos Livros de História da Matemática
}

\author{
A História da Matemática pode \\ ser instrutiva bem como agradável.
}

Cajori 105

Passaremos agora a considerar, ainda que brevemente, a seqüência mais recente dos livros de História da Matemática propriamente ditos, isto é, obras escritas com esse fim específico. A partir do século XVI, Loria106 já identifica na produção científica uma atitude de verdadeira veneração pela obra dos antigos, com

um sentimento de profunda gratidão àqueles que fizeram progredir a Ciência; isso induziu alguns autores a inserir nos seus escritos a partir daí um verdadeiro e próprio caráter histórico, com informações em torno dos predecessores ${ }^{107}$.

Desse modo, já em 1615 Giuseppe Biancani produz uma Clarorum Mathematicorum Chronologia como adendo a outra obra maior sua ${ }^{108}$. Entre outros autores desse século, destaca-se Milliet Descharles que introduziu numa obra sua o item $D e$ Progressus Matheseos et Illustrius Mathematicus ${ }^{109}$. No início do século XVII, o abade Bernardino Baldi publica suas Biografias de Matemáticos ${ }^{110}$, após um trabalho de pesquisa de quatorze anos. Essa grande obra traz 365 biografias e serviu de fonte para inúmeros trabalhos posteriores. Segundo Smith, Baldi era um lingüista de habilidades incomuns e por isso pôde com desenvoltura lidar com fontes de informação biográfica em diversas línguas ${ }^{111}$.

A primeira obra com o título de História da Matemática foi escrita em 1742 por Johann Christoph Heilbronner112. Em sua Historia Matheseos Universae, Heilbronner inclui um valiosa relação de manuscritos que podiam ser obtidos na época, além de uma lista dos últimos livros impressos. Mas a primeira verdadeira e própria História da Matemática ${ }^{113}$, segundo a expressão de Loria, é sem dúvida a Histoire des Mathématics de Jean Étienne Montucla (1725-1799) ${ }^{114}$. Sua obra constitui-se num modelo de História da Matemática totalmente cronológica. Além disso, sendo Montucla um erudito, escreveu em estilo abrangente, de modo que quase não foi superado pelas Histórias posteriores ${ }^{115}$. Pois a obra de Montucla retrata não só a Matemática pura e aplicada, mas inclui também a História da Geografia, da Música, da Gnomônica e da Navegação. Esse caráter cronológico de Montucla será tema muito importante para a compreensão dos desenvolvimentos posteriores dos tipos de livros sobre História da Matemática.

No início do século XIX uma abordagem diferente, visando a utilização didática da História da Matemática, irá surgir nas mãos do Pe. Pietro Franchini, que dedicava-se entre outras coisas ao ensino da Matemática em diversas escolas secundárias da Itália. Ele era também um matemático muito capaz, e escreveu textos de pesquisa em Matemática, principalmente sobre Análise ${ }^{116}$. Sua obra histórica, intitulada Saggio sulla

105 CAJORI, Florian. A History of Mathematics. $2^{\mathrm{a}}$ ed. New York, The MacMillan Company, 1919, 516 p., Introducion, p. I

106 Cf. LORIA, Gino. Guida allo Studio della Storia delle Matematiche. Milano, Ulrico Hoepli, 1946. 385 p.

107 Ibid., p. 26

108 BIANCANI, Giuseppe. Aristotelis loca Mathematica ex Universis Operibus Collecta et Explicata. Boloniae, 1615. Apud LORIA, op. cit., p. 17

109 DESCHARLES, Milliet. Cursus Seo Mundus Mathematicus. Lugd., 1674. Apud LORIA, op. cit., p. 17

110 BALDI, Bernardino. Cronaca de'matematic ovvero Epitome dell'istorie delle vite loro. Urbino, 1707. Apud. LORIA, op. cit., p. 18

111 Cf. SMITH, David Eugene. History of Mathematics. 2 v. Boston, Ginn and Co., 1923. V. II, 596 p., p. 539

112 HEILBRONER, Johan Cristoph. Historia Matheseos Universae a mundo condito ad seculum post Chr. Nat. XVI. Leipzig, 1742. Apud SMITH, op. cit., p. 539

113 Cf. LORIA, op. cit., p. 20

114 MONTUCLA, Jean Étienne. Histoire des Mathématics. 2 v., Paris, Jombert, 1758

115 Cf. SMITH, David Eugene. History of Mathematics. 2 v. Boston, Ginn and Co., 1923. V. II, 596 p., p. 540

116 Cf. SMITH, op. cit., p. 542 
Storia delle matematiche corredato di scelte notizie biografiche ad uso della gioventù ${ }^{117}$, marca uma nova orientação da visão da História da Matemática, que é sua vinculação ao ensino da Matemática. Essa relação entre História da Matemática e ensino da Matemática será retomada depois por outros autores.

Seguindo o modelo clássico de Montucla, irá surgir no final do século XIX e início do XX a obra que, segundo Loria, assinala uma época na História da pesquisa sobre a evolução do pensamento matemático ${ }^{118}$. Trata-se da colossal Vorlesunger über Geschichte der Mathematik, de Moritz Benedict Cantor ${ }^{119}$. Em quatro volumes, publicados entre 1880 e 1908, a obra segue um critério rigorosamente cronológico. Segundo Cajori120, Moritz Cantor é o mais notável escritor geral do século XIX sobre História da Matemática. Nasceu em Mannheim, e estudou inicialmente em Heidelberg. Em Gottingen estudou com Gauss e Weber, e em Berlim com Dirichlet. Deu aulas em Heidelberg onde em 1877 tornouse Professor Honorário. Seu primeiro artigo histórico surgiu em 1856. A diferença principal entre Cantor e Montucla está na abrangência do programa. Enquanto Montucla fala sobre a História de diversos ramos científicos, Cantor ocupa-se exclusivamente da Matemática pura. A semelhança com Montucla está justamente no modelo cronológico que segue, criticado de certa forma por Loria porque permite interrupções no tratamento de alguns assuntos, por exemplo a questão referente à criação do Cálculo Infinitesimal ${ }^{121}$.

Com Cantor, o sistema cronológico de narração fica claramente estabelecido. No início do século XX irão surgir no entanto outros tipos de tratamento da História da Matemática, além de outras edições de História da Matemática seguindo a cronologia. Um dos autores mais importantes dessa época é sem dúvida Florian Cajori. Já em 1894 tinha surgido a primeira edição de $A$ History of Mathematics ${ }^{122}$, um clássico do gênero cronológico em um só volume. Professor de História da Matemática da Universidade da Califórnia, Cajori expõe logo na introdução algumas razões que o levaram a escrever essa obra, baseadas no princípio exposto na epígrafe deste item. No prefácio à segunda edição, de 1919, ele opina que existem vantagens em fazer uma História da Matemática de um só volume para uso dos leitores que não podem dedicar-se a um estudo intensivo da História da Matemática. Por outro lado, admite que é uma tarefa difícil dar uma visão de relance adequada do desenvolvimento da Matemática de seus mais antigos começos até o tempo presente ${ }^{123}$.

Essa dificuldade apontada por Cajori foi de certo modo resolvida por David Eugene Smith, na sua History of Mathematics ${ }^{124} \mathrm{em}$ dois volumes, publicados em 1923. Smith esclarece que um texto único cronológico não é didaticamente aconselhável, e resolve essa questão planejando uma História da Matemática com dupla visão, em dois volumes com tratamento distintos:

O plano geral adotado na preparação deste trabalho é o de apresentar 0 assunto a partir de dois pontos de vista distintos, 0 primeiro, no volume I, levando a uma visão do crescimento da Matemática por períodos cronológicos, com as devidas considerações sobre as realizações étnicas; e o segundo, no volume II, levando a uma discussão da evolução de certos tópicos importantes. Tentar fundir essas duas características e assim apresentá-las foi muitas vezes pretendido. É o que caracteriza, por exemplo, o tratado monumental de Montucla e, em larga medida, o de Cantor. Para o professor, no entanto, esse plano não é satisfatório ${ }^{125}$.

\footnotetext{
117 FRANCHINI, Pietro. Saggio sulla Storia delle matematiche corredato di scelte notizie biografiche ad uso della gioventù. Lucca, 1821. Apud LORIA, p. 24

118 Cf. LORIA, op. cit., p. 26

119 CANTOR, Moritz Benedict. Vorlesunger über Geschichte der Mathematik. Berlin, Verlag und Teubner, 18801908. 4 v.

120 Cf. CAJORI, op. cit., p. 6, nota 1

121 Cf. LORIA, op. cit., p. 27

122 CAJORI, op. cit.

123 Ibid., Preface to the Second Edition

124 SMITH, David Eugene. History of Mathematics. Boston, Ginn and Co., 1923. 2 v.

125 SMITH, op. cit., v. I, Preface, p. iii
} 
Smith toma para si a tarefa de escrever um livro de História da Matemática voltado para o Professor de Matemática, portanto pautado do ponto de vista de sua aplicação didática. Esse ponto de vista não era desconhecido por Cajori, que admitia também o valor do conhecimento histórico para o Professor de Matemática ${ }^{126}$. Mas o público-alvo de Cajori constituía-se fundamentalmente de matemáticos, tendo presente que

a contemplação dos vários passos pelos quais o gênero humano tomou posse do vasto estoque de conhecimento matemático dificilmente deixa de interessar ao matemático ${ }^{127}$.

Já Smith é categórico em afirmar que sua obra foi escrita visando sua utilização por professores e alunos ${ }^{128}$. Em busca desse objetivo específico, Smith realizou uma verdadeira revolução dentro dos moldes habituais de tratar a História da Matemática. Deixa claro que um livro meramente cronológico não é suficiente para o Professor, sendo necessárias outras abordagens diferentes. Smith opta pela abordagem Por Assunto, o que marca uma nova fase na produção de livros sobre História da Matemática.

Além da sua História da Matemática em dois volumes, Smith escreveu diversas outras obras histórica, algumas em parceria com outros autores. Notável é A History of Japanese Mathematics ${ }^{129}$, ótimo exemplo de uma História da Matemática por civilização. Com Karpinsky, produz o célebre The Hindu-Arabic Numerals ${ }^{130}$, onde estabelece as bases de um profundo estudo sobre um tópico específico da História da Matemática. Compôs sozinho o inigualável $A$ Source Book in Mathematics ${ }^{131}$, no qual apresenta a evolução da Matemática através do recurso aos escritos originais de autores de diversos períodos.

Smith foi pioneiro em abrir o leque das várias abordagens alternativas. Irão depois surgir muitas obras tratando a História da Matemática segundo aspectos variados, fugindo da pretensão de esgotá-la na forma cronológica. Pareceu ficar claro para vários pesquisadores que era didaticamente mais interessante um livro sobre algum tópico específico, ou sobre uma determinada nação ou época, ou ainda livros só de biografias.

Uma nova História da Matemática por assunto será elaborada por Vera Sanford ${ }^{132}$ em 1930, sob orientação do próprio Smith. Em 1937 surge o livro biográfico de Bell ${ }^{133}$, trazendo relatos da vida dos mais famosos matemáticos de todos os tempos. Após as descobertas arqueológicas expostas por Neugebauer e Sachs ${ }^{134}$, com a tradução das tabletas matemáticas da Mesopotâmia, irão surgir outros livros explorando a História da Matemática das Civilizações Antigas, como havia feito já em 1921 Sir Thomas Little Heath com a História da Matemática grega ${ }^{135}$. É o caso de Episódios da História Antiga da Matemática ${ }^{136}$, de Asger Aaboe, e do monumental tratado sobre a Matemática da China ${ }^{137}$ de Joseph Needham. Na mesma linha virá, mais recentemente, em 1972, Richard Gillings ${ }^{138}$, narrando a Matemática egípcia do tempo dos faraós. Depois Bartel Leenert van der Waerden publicará em 1983 e em 1985 respectivamente duas grandes obras, a primeira sobre a Geometria e a Álgebra nas civilizações antigas ${ }^{139}$ e a segunda sobre a História da Álgebra de Al-Khowarismi a Emmy Noether ${ }^{140}$.

126 Cf. CAJORI, op. cit., Introduction, p. 2

127 lbid., p. 1

128 Cf. SMITH, op. cit., v. I, Preface, p. iii

129 SMITH, David Eugene \& MIKAMI, Yoshio. A History of Japanese Mathematics. Chicago, 1912.

130 SMITH, David Eugene \& KARPINSKI, L. C. The Hindu-Arabic Numerals. Boston, Ginn and Company, 1911.

131 SMITH David Eugene. A Source Book in Mathematics. New York, Dover, 1959. 2 v.

132 SANFORD, Vera. A Short History of Mathematics. New York, Houghton Mifflin, 1930. 402 p.

133 BELL, Eric Temple. Men of Mathematics. New York, Simon and Schuster, 1965. 590 p.

134 Cf. NEUGEBAUER, Otto e SACHS, A. Mathematical Cuneiform Texts. New Haven, Conn. Yale University Press, 1945.

135 HEATH, Thomas Litle. A History of Greek Mathematics. New York, Dover, 1981. 2 v.

136 AABOE, Asger. Episódios da História Antiga da Matemática. Trad. de João Pitombeira de Carvalho. Rio de Janeiro, Sociedade Brasileira de Matemática, 1984. 170 p.

137 NEEDHAM, Joseph. Science and Civilization in China. Cambridge, University Press, 1959. 3 v.

138 GILLINGS, Richard J. Mathematics in the Time of the Pharaohs. New York, Dover, 1972, 288 p.

139 VAN DER WAERDEN, Bartel Leenert. Geometry and Algebra in Ancient Civilizations. Berlin, Springer-Verlag, 1983. $223 \mathrm{p}$.

140 VAN DER WAERDEN, Bartel Leenert. A History of Algebra. Berlin, Springer-Verlag, 1985, 271 p. 
A maneira cronológica de expor a História da Matemática não será, entretanto, abandonada. Não faltarão autores no século XX que se proporão, como Carl Benjamin Boyer ${ }^{141}$ em 1968, aderir mais estritamente a um arranjo cronológico na exposição da História da Matemática, procurando

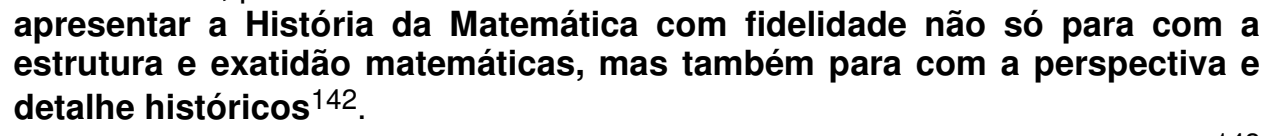
estrutura e exatidão matemáticas, mas também para com a perspectiva e detalhe históricos ${ }^{142}$.

A História da Matemática de Boyer, bem como a que Howard Eves ${ }^{143}$ escreveu em 1964, são exemplos de História da Matemática cronológica do tipo clássico, escrita com base na informação disponível atualmente. As características peculiares desse tipo cronológico e de outros tipos de livros de História da Matemática serão estudados a seguir.

141 BOYER, Carl Benjamin. História da Matemática. Trad. de Elza F. Gomide. São Paulo, Edgard Blucher, 1974, $488 \mathrm{p}$.

142 BOYER, op. cit., Prefácio

143 EVES, Howard. An Introduction to the History of Mathematics. New York, Holt, Rinehart and Winston, 1969, 464 p. 


\section{Capítulo 2 \\ Tipos de livros de História da Matemática}

Uma História da Matemática pode ser construída sobre diversos planos gerais, cada um dos quais pode ser justificado pelo objetivo em mente. Por exemplo, pode ser organizado apenas tendo em vista a seqüência cronológica de eventos, ou como uma série de biografias, ou de acordo com os principais ramos da Matemática, ou como um livro fonte de material para estudo, ou com relação a resultados obtidos por um pais ou povo, ou de vários outros modos, cada um dos quais pode ter certas vantagens.

Smith ${ }^{144}$

Tendo esboçado uma breve relação das principais fontes e livros de História da Matemática segundo sua seqüência histórica, iremos agora, nesse Capítulo 2, estudar mais detidamente alguns tipos de livro. A estrutura desse capítulo será, portanto, bem distinta do anterior. Iremos distribuir os itens segundo esses tipos de livros, e em cada um apresentaremos apenas alguns exemplos por nós considerados mais relevantes para os fins próprios desse trabalho, isto é, contribuir para o estudo do valor didático da História da Matemática. Seguindo o modelo do Guia ao Estudo da História da Matemática de Loria ${ }^{145}$, apresentaremos também a relação de conteúdo de alguns livros, ainda que, por vezes, resumidamente. Pensamos desse modo expor essas obras a um conhecimento prévio mais imediato acerca do seu conteúdo e da distribuição do mesmo pelos itens.

Os diferentes tipos de livros de História da Matemática identificados acima por Smith são também apontados por Loria no seu Guia, como segue:

As obras de maior porte relativas à História da Ciência podem ser distribuídas nas seguintes categorias:

a) Biografia;

b) Historia de determinada teoria;

c) História de uma determinada Ciência em uma região préestabelecida (estado, província, nação);

d) História geral de uma disciplina;

e) Crestomatia (Antologia) ${ }^{146}$.

Interessava a Loria sobretudo caracterizar esses tipos de livros de História da Matemática para que os pesquisadores que desejassem escrever um livro pudessem optar por um modelo a seguir. Como o fim do nosso trabalho é servir de introdução ao estudo do valor didático da História da Matemática, escolhemos alguns tipos de livro que julgamos adequados para servir de base para as discussões posteriores. Essa classificação não pretende ser, portanto, exaustiva, nem no que se refere aos tipos de livros nem quanto às obras que escolhemos comentar. A divisão que adotamos é a seguinte:
1. Cronologias;
2. Biografias;
3. Por Assunto;
4. Outros.

\footnotetext{
144 SMITH, David Eugene. History of Mathematics. Boston, Ginn and Co., 1923. 2 v. V. I, Preface, p. iii

145 LORIA, Gino. Guida allo Studio della Storia delle Matematiche. 2a ed. Milano, Ulrico Hoepli, 1946. 385 p.

146 LORIA, op.cit., p. 259
} 


\title{
2.1 Cronologias
}

\begin{abstract}
Devem ser os historiadores muito pontuais, verdadeiros, e nada apaixonados, sem que nem interesse, nem temor, nem ódio, nem afeição, os desviem do caminho direito da verdade, que é a filha legítima de quem historia, êmula do tempo, depósito dos feitos, testemunha do passado, exemplo e conselho do presente, e ensino do futuro.
\end{abstract}

Cervantes $^{147}$

O modelo clássico de obra sobre História da Matemática constitui-se num relato das diferentes manifestações matemáticas seguindo a linha do tempo. Nesse sentido assemelha-se muito a uma História Geral da Humanidade, só que em vez de enfocar todos os aspectos históricos detém-se fundamentalmente no conhecimento matemático de cada época, valendo-se das obras matemáticas e de outros indícios históricos relacionados com a evolução da Ciência ao longo do tempo.

Nas palavras de Loria,

a História da Matemática, como qualquer ramo da História, é uma reconstrução do passado feita com $o$ auxílio de todas as fontes de informação hoje existentes ${ }^{148}$.

Nessa reconstrução do passado, os autores de livros cronológicos de História da Matemática procuram de modo geral ressaltar os elementos de ligação que permitam discernir uma certa linha de desenvolvimento da Matemática ao longo da História. Para muitos deles, como expõe Cajori, a História da Matemática representa

uma das amplas janelas através das quais o olho filosófico volta-se para idades passadas e traça a linha do desenvolvimento intelectual ${ }^{149}$.

Por isso, uma das maiores características desses livros é que raramente servem de fonte para conhecer profundamente a Matemática de uma época determinada. Esse tipo de livro apenas se limita a fazer uma descrição sucinta do conhecimento matemático de uma época, fornecendo alguns exemplos de problemas e mencionando algumas obras de autores dessa época. Para se conhecer melhor a Matemática de uma época determinada é necessário recorrer a outros tipos de livros de História da Matemática, dos quais falaremos mais adiante.

Uma tentativa de elaborar um estudo mais aprofundado, mantendo ainda a estrutura cronológica, resultou na monumental Vorlesungen über die Gerchichte der Mathematik, de Moritz Benedict Cantor ${ }^{150}$. Com quase quatro mil páginas, essa obra pode ser considerada como o modelo dos tratados sobre o assunto, como afirma Ball ${ }^{151}$. Entretanto, podemos comparar a obra de Cantor com a de Raymond Claire Archibald, Outline on the History of Mathematics ${ }^{152}$, em termos de estrutura narrativa. Ambas seguem o mesmo modelo cronológico de narração, dentro do qual a seqüência é bem mais importante que o aprofundamento nos tópicos abordados. Só que a parte propriamente histórica da obra de Archibald não ultrapassa as cinqüenta páginas, dentro das quais vemos passar como um relâmpago cinco mil anos de História. Entre esses extremos, encaixam-se os livros cronológicos de tamanho padrão, girando em torno de quinhentas páginas. Quatro obras principais serão aqui comparadas, o que pareceu suficiente para fornecer uma boa idéia do que vem a ser um livro de História da Matemática segundo a cronologia.

\footnotetext{
147 CERVANTES, Miguel de. O Engenhoso Fidalgo Dom Quixote de la Mancha. Tradução de Viscondes de Castilho e Azevedo. São Paulo, Abril Cultural, 1978. 609 p. p. 61

148 LORIA, op. cit., p. 3

149 CAJORI, Florian. A History of Mathematics. $2^{\mathrm{a}}$ ed. New York, The MacMillan Company, 1919, 516 p., p. 3

150 CANTOR, Moritz Benedict. Vorlesunger über Geschichte der Mathematik. Berlin, Verlag und Teubner, 18801908. $4 \mathrm{v}$.

151 BALL, Walter William Rouse. A Primer of the History of Mathematics. London, MacMillan and Co., 1930. 149 p., p. vii

152 ARCHIBALD, Raymond Clare. Outline on the History of Mathematics. Ohio, Mathematical Association of America, 1941, $76 \mathrm{p}$
} 


\section{Cajori: Uma História da Matemática}

A obra de Cajori é bastante sintética, principalmente no que se refere à Matemática Antiga. Por exemplo, dedica apenas cinco páginas à Babilônia e seis ao Egito. No item sobre os egípcios, apresenta alguns problemas do Papiro Ahmes, considerando que representam os resultados mais avançados dos egípcios em Aritmética e Geometria. ${ }^{153}$ Ao apresentá-los de forma tão sucinta, Cajori deixa o leitor sem poder conferir como era exatamente essa Matemática, não podendo por si mesmo avaliar seu grau de sofisticação nem sua possível aplicação didática para o ensino de Matemática elementar. Mas é preciso ter em conta, além disso, que na época em que o livro foi escrito ainda não haviam surgido os estudos de Neugebauer e Sachs sobre as tabletas babilônias.

\begin{tabular}{|lr|}
\hline \multicolumn{2}{|c|}{ CAJORI, Florian. A History of Mathematics. } \\
$2^{\mathrm{a}}$ ed. New York, The MacMillan Company, \\
1919, 516 p. \\
\hline \multicolumn{2}{|c|}{ Conteúdo: } \\
\hline Babilônios & 4 \\
Egípcios & 9 \\
Gregos & 15 \\
Romanos & 63 \\
Maias & 69 \\
Chineses & 71 \\
Japoneses & 78 \\
Hindus & 83 \\
Árabes & 99 \\
Europa durante a Idade Média & 113 \\
Europa durante os séculos XVI, & 130 \\
XVII e XVIII & \\
Os séculos XIX e XX & 278 \\
\hline
\end{tabular}

Cajori dedica inicialmente um item para cada civilização: gregos, chineses, romanos, maias, etc. Sua narrativa cronológica é portanto sincopada, e esses saltos de um povo a outro podem atrapalhar a visão evolutiva da Ciência em si.

Por exemplo, no item sobre os romanos cita Santo Agostinho (354-430), o qual, segundo ele, merece o crédito de aceitar a existência do infinito real ${ }^{154}$, após ter estudado os paradoxos do movimento propostos pelo grego Zeno de Eléa no século $\mathrm{V}$ aC. $\mathrm{O}$ mesmo assunto volta a aparecer no item sobre a Europa na Idade Média, quando São Tomás de Aquino (1225-1274) explica os argumentos de Zeno contra o movimento conforme a exposição de Aristóteles ${ }^{155}$. Ou seja, uma interessante questão sobre a evolução da noção de infinito fica espalhada ao longo do livro, de modo que seu potencial didático se dilui em função do esquematismo cronológico do texto.

\section{Smith: História da Matemática (Volume 1)}

Conforme já foi mencionado, a obra dupla de Smith consegue resolver os problemas do modelo cronológico, deslocando para um segundo volume o tratamento em separado das linhas evolutivas de cada tópico da Matemática elementar. Cabe aqui somente observar que seu volume um, estritamente cronológico, é dos melhores exemplos do gênero, por organizar o conteúdo exclusivamente de acordo com a linha do tempo. Parece que Smith conseguiu ser tão rigidamente cronológico justamente por ter reservado todas as correlações temáticas para o segundo volume, restando no primeiro apenas uma esquematização temporal simples. Decorre disso que o primeiro volume de Smith traz a evolução da Matemática tratada de um modo assumidamente compartimentalizado. Cada item aborda um período histórico e dentro dele há ainda uma divisão do assunto pelas principais civilizações que floresceram naquela época. Civilizações milenares como a da China aparecem portanto em quase todos os itens.

\footnotetext{
153 Cf. CAJORI, op. cit., p. 14

154 Cf. ibid., p. 67

155 Cf. ibid., p. 126
} 


\begin{tabular}{|lr|}
\hline \multicolumn{2}{|c|}{ SMITH, David Eugene. History of } \\
Mathematics. Boston, Ginn and Co., 1923. 2 \\
v. Volume I, 596 p. \\
\hline \multicolumn{2}{|c|}{ Conteúdo: } \\
\hline Matemática Pré-Histórica & 1 \\
Período Histórico até 1000 aC & 20 \\
Período de 1000 a 300 aC & 54 \\
Período de 300 aC a 500 aC & 102 \\
Período de 500 a 1000 & 148 \\
Ocidente de 1000 a 1500 & 194 \\
Oriente de 1000 a 1500 & 266 \\
Século Dezesseis & 292 \\
Século Dezessete & 358 \\
Século Dezoito e Seguintes & 444 \\
\hline
\end{tabular}

Já que a questão da evolução por tópicos está reservada para o volume dois, Smith pode explorar ao máximo nesse primeiro volume uma visão bastante cronológica da História da Matemática. Consegue deixar claro, por exemplo, que no período de 500 a 1000 (Item V) havia muitas Matemáticas distintas acontecendo simultaneamente no mundo: China, Japão, Índia, Pérsia e Arábia, Ocidente Cristão, Oriente Cristão e Espanha. Compreende-se também o destaque dado a essa última devido ao particular intercâmbio cultural e científico ocasionado pela convivência entre árabes e cristãos na Espanha nessa época ${ }^{156}$.

Após Smith, outros autores tentaram misturar a narrativa cronológica com uma certa flexibilidade para discutir a evolução particular de alguns tópicos. É o que procura fazer Howard Eves na sua obra. Por exemplo, no meio do item sobre a Matemática Grega de Tales a Euclides, ao falar sobre o problema da Quadratura do Círculo, Eves se interrompe para fazer uma cronologia de $\pi$, na qual descreve o cálculo do número $\pi$ desde 240 aC até 1949157. Essa flexibilidade do livro de Eves se percebe pela própria divisão de itens que, longe de ser abrangente como Smith, se limita ao que parece mais relevante da seqüência histórica.

\section{Eves: Uma Introdução à História da Matemática}

\begin{tabular}{|lr|}
\hline \multicolumn{2}{|c|}{$\begin{array}{c}\text { EVES, Howard. An Introduction to the } \\
\text { History of Mathematics. New York, Holt, } \\
\text { Rinehart and Winston, 1969, 464 p. }\end{array}$} \\
\hline \multicolumn{2}{|c|}{ Conteúdo: } \\
\hline Sistemas de Numeração & 7 \\
Matemática Egípcia e Babilônia & 27 \\
Matemática Pitagórica & 49 \\
Duplicação, Trissecção e & 77 \\
Quadratura & 112 \\
Elementos de Euclides & 142 \\
Matemática Grega após Euclides & 180 \\
Matemática Hindu e Árabe & 206 \\
Matemática Européia, de 500 a & \\
1600 & 243 \\
A Aurora da Matemática & \\
Moderna & \\
Geometria Analítica e Outros & \\
Desenvolvimentos Pré-Cálculo & 280 \\
O Cálculo e Conceitos & 315 \\
Relacionados &
\end{tabular}

156 Cf. SMITH, op. cit., v. I,p. 192

157 Cf. EVES, op. cit., p. 89 
Eves não visa produzir uma História da Matemática estritamente cronológica, mas quer apenas construir um caminho percorrendo as etapas principais da evolução da Matemática. Conforme esclarece, sua obra é uma tentativa de introdução à História da Matemática que possa servir como livro-texto para um curso de Graduação de um semestre, com três horas por semana ${ }^{158}$. Já que seus fins são didáticos, Eves viu-se forçado a sair um pouco do esquema cronológico rígido, para tentar dar mais sentido aos tópicos que escolheu abordar.

Um grande apreciador da obra de Eves é sem dúvida Carl Benjamin Boyer. Refere-se ao livro de Eves como o mais bem sucedido e apropriado da sua época, afirmando que utilizou-o com grande satisfação, em diversos cursos de História da Matemática que ministrou. Em seguida prossegue Boyer:

Ocasionalmente eu modifiquei a ordem dos tópicos no livro, procurando alcançar uma maior intensidade de sentimento histórico, e suplementei o material com mais referências às contribuições dos séculos dezoito e dezenove ${ }^{159}$.

O fato de que Boyer tenha precisado alterar a ordem do livro justamente para obter uma maior coesão histórica, constitui-se em mais um sinal de que o livro de Eves não é uma História da Matemática cronológica rígida.

\section{Boyer: História da Matemática}

Já a intenção de Boyer ao escrever sua obra era precisamente construir uma narrativa cronológica com destaque para dados históricos. De fato, ele obtém uma grande densidade de informações históricas, e seu texto é aproximadamente regido pela seqüência cronológica. A homogeneidade da narrativa é às vezes comprometida por interrupções ocasionadas por sua intenção de ser mais profundo em alguns pontos. Descrições de conteúdo de obras, digressões biográficas ou com sentido estritamente cronológico, tornam-se às vezes desvios do curso narrativo, dificultando a leitura do livro como um texto fluente. Vejamos, por exemplo, um trecho extraído da página 24l:

Galileu tinha tido a intenção de escrever um tratado sobre o infinito em matemática, mas ele não foi encontrado. Enquanto isso, seu discípulo Cavalieri fora estimulado pela Stereometria de Kepler, bem como por idéias antigas e medievais e pelo encorajamento de Galileu, a organizar seus pensamentos sobre infinitésimos em forma de livro. Cavalieri era membro de uma ordem religiosa (dos Jesuados, não dos jesuitas como se tem dito frequentemente mas incorretamente) e viveu em Milão e Roma antes de tornar-se professor em Bolonha em 1629. Caracteristicamente para seu tempo ele escreveu sobre muitos aspectos da matemática pura e aplicada - geometria, trigonometria, astronomia e óptica - e foi o primeiro autor italiano a apreciar o valor dos logaritmos. Em seu Directorium universale uranometricum de 1632 ele publicou tabelas de senos, tangentes, secantes e senos versos, junto com seus logaritmos, até oito casas; mas ele é relembrado mais por um dos livros mais influentes do início do período moderno, a Geometria indivisibilibus continuorum, publicada em 1635. 160

\begin{tabular}{|l|r|l|r|}
\hline \multicolumn{4}{|c|}{$\begin{array}{l}\text { BOYER, Carl Benjamin. História da Matemática. Trad. de Elza F. Gomide. São Paulo, Edgard } \\
\text { Blücher, 1974, 488 p. }\end{array}$} \\
\hline \multicolumn{3}{|c|}{ Conteúdo: } & 197 \\
\hline Origens primitivas & 1 & A Renascença & 222 \\
\hline Egito & 7 & Prelúdio à Matemática Moderna & 245 \\
\hline Mesopotâmia & 18 & O Tempo de Fermat e Descartes & 270 \\
\hline Jônia e os Pitagóricos & 33 & Um Período de Transição & 287 \\
\hline A Idade Heróica & 47 & Newton e Leibniz & \\
\hline
\end{tabular}

158 Cf. ibid., p. 1

159 BOYER, Carl Benjamin. História da Matemática. Trad. de Elza F. Gomide. São Paulo, Edgard Blucher, 1974, 488 p. Prefácio

160 Cf. ibid., p. 241 


\begin{tabular}{|l|r|l|r|}
\hline A Idade de Platão e Aristóteles & 61 & Era Bernoulli & 306 \\
\hline Euclides de Alexandria & 74 & A Idade de Euler & 324 \\
\hline Arquimedes de Siracusa & 89 & $\begin{array}{l}\text { Matemática da Revolução } \\
\text { Francesa }\end{array}$ & 344 \\
\hline Apolônio de Perga & 104 & O Tempo de Gauss e de Cauchy & 367 \\
\hline $\begin{array}{l}\text { Trigonometria e Mensuração na } \\
\text { Grécia }\end{array}$ & 116 & A Idade Heróica da Geometria & 387 \\
\hline $\begin{array}{l}\text { Ressurgimento e Declínio da } \\
\text { Matemática Grega }\end{array}$ & 129 & A Aritmetização da Análise & 404 \\
\hline China e Índia & 143 & $\begin{array}{l}\text { O Surgimento da Álgebra } \\
\text { Abstrata }\end{array}$ & 419 \\
\hline A Hegemonia Árabe & 165 & Aspectos do Século Vinte & 440 \\
\hline A Europa na Idade Média & 180 & & \\
\hline
\end{tabular}

Como vemos no exemplo citado acima, a pesquisa de material que gerou o livro de Boyer foi tão vasta que permitiria a elaboração de vários volumes, cada qual de um tipo, o que seria muito interessante. Por exemplo, se poderia obter um volume só com uma narrativa cronológica contínua, sem entrar em pormenores. Um segundo tomo abrangeria o desenvolvimento particular de alguns tópicos da Matemática, com suficientes detalhes para que se possa compreender bem a evolução daquele assunto. Um terceiro volume poderia dedicar-se a tratar das obras de Matemática que tiveram especial importância para 0 progresso da Ciência. Outro livro poderia conter biografias, etc.

Uma boa forma de aproveitar essa valiosa quantidade de informações contidas na obra de Boyer parece ser através do índice por temas que oferece na página 475. É claro que isso toma tempo, mas é mais útil para o professor ou para quem esteja interessado num assunto específico. Apenas para ilustrar esse modo de utilização, basta ver que a seqüência de páginas indicadas para que se conheça a História do Número $\pi$ é: 8,13 , $15,28,93,104,122,125,129,144,147,153,154,157,160,162,177,222,235,280,283$, 297.

Outra forma mais simples é ir pulando as páginas em que há uma interrupção na narrativa. Por exemplo, a descrição de dez páginas sobre Os Elementos de Euclides $^{161}$ não necessariamente se imporia a quem estivesse acompanhando a evolução da Matemática na Grécia no ritmo das páginas anteriores. Além disso, uma obra com Os Elementos merece ser considerada numa edição integral ${ }^{162}$, já que por si só tem muito a dizer sobre a História da Matemática.

161 Cf. ibid., p. 77

162 Por exemplo, The Thirteen Books of Euclid's Elements. Trad. e com. por Thomas Little Heath. $2^{\mathrm{a}}$ ed. New York, Dover, 1956. 13v. em 3 


\title{
2.2 Biografias
}

\author{
Aqueles que nunca conheceram \\ um matemático profissional podem ficar muito \\ surpresos ao encontrar algum.
}

Bell 163

Conhecer as vidas dos matemáticos sem dúvida contribui para tornar mais atraente o ensino da Matemática, revelando o fundo humano por trás da sua aparente frieza exata. Assim justifica Smith a introdução de alguns relatos sobre a vida de matemáticos mencionados na sua História da Matemática cronológica, a qual traz

anedotas suficientes para quebrar a monotonia da mera narrativa histórica e para revelar o matemático como um ser humano como outros de sua espécie ${ }^{164}$.

Podemos, pelo mesmo motivo, encontrar biografias de matemáticos permeando quase todo tipo de livro sobre História da Matemática. Mas existem obras especializadas trazendo unicamente biografias. $O$ interesse pelas biografias é ressaltado por Gil em seu artigo Biografías: un Género en Auge. Segundo ele,

O gênero biográfico é uma aproximação à História através do concreto, da anedota, do pequeno acontecimento que, no entanto, tem uma grande transcendência ${ }^{165}$.

Outra razão para a existência dessas obras é explicada por Bell no início de sua obra biográfica. Afirma ele que é fundamental conhecer a vida dos matemáticos para não olhá-los como seres estranhos:

Os matemáticos enquanto uma classe provavelmente são menos familiares para o leitor em geral que qualquer outro grupo de trabalhadores intelectuais. $O$ matemático é um personagem muito mais raro na ficção que seu primo o cientista, e quando de fato aparece nas páginas de um romance ou numa tela de cinema não passa de um desalinhado sonhador totalmente desprovido de senso comum - digno de riso. Que tipo de mortal é ele na vida real? Apenas vendo em detalhe que espécie de homem alguns dos grandes matemáticos foram e que tipo de vida tiveram, podemos reconhecer a ridícula falsidade do retrato tradicional de um matemático ${ }^{166}$.

Para quebrar essa falsa imagem dos matemáticos, Bell realizou uma extensa obra: quase seiscentas páginas relatando as vidas de mais de trinta matemáticos. Bell teve que fazer uma escolha cuidadosa de sobre quem falar, pois a Matemática é obra de uma multidão. Segundo ele,

o exército daqueles que fizeram pelo menos uma contribuição definida para a Matemática tal qual a conhecemos torna-se logo uma multidão quando olhamos para trás através da História; 6000 ou 8000 nomes acotovelam-se por alguma palavra nossa que os preserve do esquecimento, e uma vez que os maiores líderes sejam reconhecidos, torna-se em grande parte uma questão de escolha arbitrária e ilógica decidir quem dentre a multidão irá sobreviver e quem será condenado a ser esquecido ${ }^{167}$.

Do meio dessa multidão de biografáveis, Bell escolheu alguns segundo dois critérios: a importância de sua obra para a Matemática atual e o atrativo humano da sua vida e personalidade ${ }^{168}$. Em sua obra estão biografados os matemáticos mais famosos desde Descartes, e antes dele há ainda a menção de três gregos: Zeno, Eudoxo e Arquimedes. Os critérios de escolha de Bell são justificados a partir de suas afirmações, recolhidas acima, acerca da arbitrariedade necessária de uma escolha entre uma multidão quase indistinta.

\footnotetext{
163 BELL, Eric Temple. Men of Mathematics. New York, Simon and Schuster, 1965. 590 p.BELL, Men

164 SMITH, David Eugene. History of Mathematics. 2 v. Boston, Ginn and Co., 1923. V. I, 596 p., Prefácio, p. V

165 GIL, André. Biografías: un género en auge. La Historia, de la mano de sus protagonistas. Madrid, ACEPRENSA, 14 Octubre 1987. Servicio 135/87

166 BELL, op. cit., p. 8

167 Ibid., p. 12

168 Cf. Ibid., p. 3
} 
A utilidade didática dessas biografias certamente suplanta o puro efeito de motivação que toda história bem contada e interessante pode causar. Elas servem para mostrar a maneira como uma determinada idéia surgiu para o matemático, e isso pode ser utilizado como modelo para a organização do mesmo conteúdo de forma que os alunos reconstruam aquela idéia para si. Muitas vezes, de acordo com a série a que se dirige a aula, o professor pode suprimir ou acrescentar pormenores matemáticos ao relato biográfico, 0 que de modo algum representa uma adulteração na História da Matemática, pois dela se mantém a estrutura lógica da construção do conceito matemático.

Exemplo já clássico pode ser obtido na leitura da biografia de Gauss, na parte relativa a sua infância, quando aos dez anos de idade resolveu quase instantaneamente um longo e trabalhoso problema de adição. Nas palavras de Bell:

O problema era do seguinte tipo, $81297+81495+81673+$ $\ldots+100899$, onde o passo de um número para o próximo é sempre o mesmo (aqui 198), e um dado número de termos (aqui 100) devem ser somados.

Era costume na escola que o garoto que obtivesse primeiro a resposta colocasse sua lousa sobre a mesa; o próximo colocava sua lousa em cima da primeira, e assim por diante. $O$ problema mal tinha sido ditado, quando Gauss atirou sua lousa sobre a mesa: "Aí está!", disse (...). Na lousa de Gauss havia um único número. Até o fím da sua vida Gauss adorava dizer como o único número que tinha escrito era a resposta correta e como todas as outras estavam erradas ${ }^{169}$.

O Professor não precisa necessariamente utilizar os mesmos números presentes no relato da soma da Progressão Aritmética por Gauss, mas essa anedota pode tornar-se menos útil se não se fizer referência ao modo como Gauss raciocinou, observando que a soma do primeiro termo com o último era a mesma do segundo com o penúltimo, e assim por diante, e daí deduzindo a fórmula da soma da Progressão Aritmética. Parece evidente que o processo de obtenção dessa fórmula fica mais razoável se o professor utiliza essa mesma seqüência lógica, mesmo que em lugar de números muito grandes coloque a soma de 1 a 100 , por exemplo.

\section{Bell: Homens da Matemática}

BELL, Eric Temple. Men of Mathematics. New York, Simon and Schuster, 1965. 590 p.

\begin{tabular}{|c|c|c|}
\hline \multicolumn{3}{|c|}{ Conteúdo: } \\
\hline 1 & Introdução & 3 \\
\hline 2 & $\begin{array}{l}\text { Zeno (século V aC), Eudoxo (408-355 aC) e Arquimedes (287?- } \\
212 \text { aC) }\end{array}$ & 19 \\
\hline 3 & Descartes (1596-1650) & 35 \\
\hline 4 & Fermat (1601-1665) & 56 \\
\hline 5 & Pascal (1623-1662) & 73 \\
\hline 6 & Newton (1642-1727) & 90 \\
\hline 7 & Leibniz (1646-1716) & 117 \\
\hline 8 & Os Bernoulli (séc. XVII e XVIII) & 131 \\
\hline 9 & Euler (1707-1783) & 139 \\
\hline 10 & Lagrange (1736-1813) & 153 \\
\hline 11 & Laplace (1749-1827) & 172 \\
\hline 12 & Monge (1746-1818), Fourier (1768-1830) & 183 \\
\hline 13 & Poncelet (1788-1867) & 206 \\
\hline 14 & Gauss (1777-1855) & 218 \\
\hline 15 & Cauchy (1789-1857) & 270 \\
\hline 16 & Lobatchewsky (1793-1856) & 294 \\
\hline 17 & Abel (1802-1829) & 307 \\
\hline 18 & Jacobi (1804-1851) & 327 \\
\hline 19 & Hamilton (1805-1865) & 340 \\
\hline 20 & Galois (1811-1832) & 362 \\
\hline
\end{tabular}

169 lbid., p. 222 
21 Sylverter (1814-1897); Cayley (1821-1895)

22 Weirstrass (1815-1897); Sonja Kowalewski (1850-1891) 406

23 Boole (1815-1864)

24 Hermite (1822-1901)

25 Kronecker (1823-1891)

26 Riemann (1826-1866)

27 Kummer (1810-1893); Dedekind (1831-1916)

O uso didático de um livro de biografias como o de Bell não é tarefa fácil, pois, como ele mesmo diz, não se trata propriamente de uma História da Matemática:

Este livro não é uma História da Matemática, ou qualquer secção de tal História ${ }^{170}$. Os itens não necessitam ser lidos consecutivamente. De fato, aqueles com uma tendência especulativa ou filosófica podem preferir ler o último item primeiro ${ }^{171}$.

Isso se dá porque Bell não faz questão alguma de tecer um fio condutor que ligue as vidas dos matemáticos formando uma História da Matemática. Além disso, pelo fato de Bell ter como critério de escolha a contribuição de seus biografados para a Matemática atual, não se pode esperar dele muitos relatos associados à Matemática elementar, como esse da infância de Gauss.

Outro fato que dificulta em parte a utilidade didática do livro de Bell é o que surge logo nessa pequena narrativa sobre a soma da P.A. Apesar de ter afirmado na introdução sua intenção de mostrar o matemático como um ser humano comum, na verdade o que faz é enfatizar o caráter de genialidade dos homens retratados. Talvez querendo tornar os relatos mais atrativos, ressalta o que há de insólito, gratuito e inexplicável na habilidade matemática dos biografados, em contraste com a mediocridade de alguns outros personagens. Não parece haver razão, por exemplo, para demolir através de uma caricaturização grotesca, a imagem de Büttner, professor da infância de Gauss. Fosse ou não especialmente dotado para a Matemática ou mesmo para o ensino, o fato é que Büttner demonstrou uma atitude de humildade e generosidade que, esta sim, pode servir de exemplo:

Do seu próprio bolso ele pagou pelo melhor livro de aritmética que se podia obter e deu-o de presente a Gauss. $O$ garoto voou através do livro. "Ele está além de mim", disse Büttner; "Não posso ensinar-lhe mais nada"172.

Essa visão do conhecimento matemático como apenas acessível a poucos especialmente dotados não parece ser muito adequada para promover a motivação para o estudo da Matemática, pois abre caminho para que o aluno, à primeira dificuldade, desista com a saída fácil de que "não nasceu para aquilo". Um gênio inato pode ser objeto de admiração, mas nunca de imitação. Nesse sentido, não parece ser muito útil pintar os maiores expoentes da Matemática carregando exageradamente nas tintas da sua genialidade incomparável. E é isso o que faz Bell ao longo de todo seu livro. O que entretanto não impede que se faça um uso mais adequado das informações biográficas contidas no livro de Bell.

Não há necessidade alguma de que as biografias de personalidades tenham um tom caricaturesco. Loria, ao falar sobre o papel das biografias na História da Matemática, apenas sugere que se forneçam dados suficientes para que fique bem caracterizado o ambiente em que se desenvolveu o matemático em questão:

Se se trata de uma biografia destinada ao grande público, deve-se expor amplamente tudo quanto se refira à sua vida e às características do ambiente em que trabalhou e limitar-se a uma exposição, clara e precisa, mas resumida da sua obra científica, destacando as invenções e projetos de mais fácil compreensão e de maior vulto ${ }^{173}$

\footnotetext{
170 lbid., p. 3

171 lbid., p. 6

172 Ibid., p. 222

173 LORIA, Gino. Guida allo Studio della Storia delle Matematiche. $2^{a}$ ed. Milano, Ulrico Hoepli, 1946. 385 p., p. 261
} 
Esses critérios sugeridos por Lória são úteis também para o professor, que ao fazer uso de uma biografia deve ter o cuidado de destacar aquilo da obra do matemático que mais esteja adequado ao nível de compreensão de seus alunos. Podemos ilustrar isso com o exemplo abaixo, mostrando que também um matemático tem senso de humor (no caso, Euler, na corte russa):

Convidado por Catarina a Grande para visitar sua corte, Diderot passou o tempo tentando converter os cortesãos ao ateísmo. Aborrecida, Catarina imcumbiu Euler de fazer calar o filósofo tagarela. Isso era fácil pois toda Matemática era chinês para Diderot(...). Foi informado de que um sábio matemático possuía uma demonstração algébrica da existência de Deus, e a apresentaria diante de toda a corte, se ele desejasse ouvi-la. Diderot alegramente consentiu... Euler avançou em direção a Diderot, e disse gravemente, e num tom de perfeita convicção:

"Senhor, $\left(a+b^{n}\right) / n=x$, portanto Deus existe; replique"!

Pareceu fazer sentido para Diderot. Humilhado pela gargalhada desatada que recebeu seu silêncio embaraçado, o pobre homem pediu a permissão de Catarina para retornar imediatamente à França. Ela graciosamente consentiu ${ }^{174}$.

Apesar do humor (duvidoso) desse tipo de episódio, pode servir não só para tornar uma aula mais animada, mas sobretudo para fazer uma ligação com o conteúdo. Esse exemplo de Euler pode ser utilizado numa aula de Lógica, pois lida com elementos como premissas, conclusões, etc. Nesse contexto, o relato adquire maior valor didático.

174 BELL, op. cit., p. 147 


\section{Coolidge: Matemática dos Grandes Amadores}

Seguindo critérios um tanto diferentes dos de Bell, Coolidge escreveu sua obra biográfica, dando, no próprio título, destaque ao fato de que a ele não interessavam tanto os matemáticos profissionais. Coolidge considerou que

através dos séculos têm havido um certo número de homens, não matemáticos profissionais, que fizeram contribuições significativas para essa, a mais antiga das Ciências.

Pareceu-me que valia a pena fazer algum estudo das contribuições desses homens que, por falta de um termo melhor, chamei amadores ${ }^{175}$.

Dezesseis personagens figuram entre os biografados por Coolidge, tendo em comum o fato de exercerem outras atividades profissionais que não a de matemáticos. Coolidge admite que não é consistente na escolha desses personagens, tendo procedido com base em critérios pessoais ao excluir outras possibilidades de matemáticos amadores e ao incluir outros que Bell considera simplesmente matemáticos, como Pascal. Algumas biografias são muito curtas, sendo entretanto valiosas, como é o caso de George Louis Leclerc, Conde de Büffon, cuja maior obra foi uma monumental História Natural em vários volumes. Büffon interessou-se pela probabilidade geométrica, inventando alguns exemplos clássicos, como o que veio a ser conhecido como o problema da agulha de Büffon:

Traçam-se no chão linhas paralelas cuja distância é d. Uma agulha de comprimento $\mathrm{k}<$ é jogada ao acaso no solo. Qual a probabilidade de que cruzará uma das linhas?

(...)O problema da agulha foi estudado experimentalmente por um grupo de pessoas, em parte como um divertido método de calcular o valor de $\pi^{176}$.

Esse problema é de muita utilidade para se fazer um estudo prático tanto de probabilidade geométrica quanto de aproximações do valor de $\pi$. Além disso, constituí-se num exemplo da aplicação da Matemática, pois os cálculos de Büffon servem hoje à técnica da tomografia.

\begin{tabular}{|rlr|}
\hline \multicolumn{2}{|c|}{ COOLIDGE, Julian Lowell. Mathematics of Great Amateurs. } \\
Oxford, Claredon, 1950. 211 p. \\
\hline \multicolumn{1}{|c|}{ Conteúdo: } \\
\hline 1 & Platão & 19 \\
2 & Omar Khayyám & 30 \\
3 & Pietro Dei Franceschi & 43 \\
4 & Leonardo da Vinci & 61 \\
5 & Albrecht Dürer & 71 \\
6 & John Napier, Barão de Marchiston & 89 \\
7 & Blaise Pascal & 103 \\
8 & Antoine Arnauld & 119 \\
9 & Jan de Witt & 132 \\
10 & Johann Heinrich Hudde \\
11 & William, Visconde Brouncker & 136 \\
& & 147 \\
12 & Guillaume L'Hospital, Marquês de & 171 \\
& Saintemesme & 178 \\
13 & Büffon & 186 \\
15 & Denuis Diderot & 195 \\
16 & Bernhard Bolzano \\
\hline
\end{tabular}

Coolidge é, de modo geral, mais sucinto em suas narrativas biográficas que Bell, sem entrar em dados muito pessoais da vida dos seus biografados. Pode-se dizer que Coolidge se encaixa melhor dentro do estilo de livros de biografias para especialistas que Loria caracteriza como sendo distinto das biografias populares:

\footnotetext{
175 COOLIDGE, Julian Lowell. Mathematics of Great Amateurs. Oxford, Claredon, 1950. 211 p., Preface

176 lbid., p. 176
} 
De modo diametralmente oposto deverá comportar-se quem queira escrever uma biografia destinada aos especialistas(...). Quanto à vida, será lícito evitar toda a parte anedótica, tendo em conta exclusivamente os acontecimentos que em certa medida influíram, favorecendo-a ou dificultando-a, sobre a produção científica do protagonista $^{177}$.

Coolidge não fornece portanto muitas anedotas biográficas interessantes como as que abundam em Bell. Entretanto, ao retratar a produção matemática de amadores, aproxima-se mais dos fins do ensino da Matemática elementar, já que os alunos não visam diretamente, salvo contadas exceções, preparar-se para uma futura dedicação profissional à pesquisa em Matemática.

Além dos livros que trazem um conjunto de biografias, existem também biografias individuais em um único volume, como as de Galois ${ }^{178}$, Diofanto ${ }^{179}$, Fermat ${ }^{180}$, Gauss $^{181}$, etc. Esses livros são uma fonte grande de informação para quem se interessa por História da Matemática, fornecendo muitos dados com profundidade razoável e reflexões pausadas.

Num outro extremo situam-se as rápidas notas biográficas de publicações do tipo Quem é Quem ${ }^{182}$. Ali encontram-se dados precisos sobre a vida dos matemáticos, numa sucinta relação de algumas linhas. Isso também tem sua utilidade, fundamentalmente para conferência de dados biográficos.

177 LORIA, op. cit., p. 262

178 INFELD, Leopold. Whom the Gods Love: the Story of Evariste Galois. New York, McGraw-Hill, 1948. 323p.

179 HEATH, Thomas Little. Diophantus of Alexandria: a Study in the History of Greek Algebra. New York, Dover, 1964. $387 \mathrm{p}$.

180 MAHONEY, Michael Sean. The Mathematical Career of Pierre de Fermat (1601-1665). New Jersey, Princeton University Press, 1973. 419 p.

181 BÜHLER, Walter Kaufmann. Gauss: A Biographical Study. New York, Springler-Verlag, 1981. 208 p.

182 Ver, por exemplo, World Who's Who in Science. Chicago, Marquis, 1968. 1855 p. 


\title{
2.3 Por assunto
}

\author{
É com grande prazer que se \\ observa a transição de um negativo "Sempre odiei \\ Matemática" para o mais positivo "Por que \\ ninguém nos contou essas coisas antes? Faz tudo \\ tão mais interessante e significativo".
}

Groza ${ }^{183}$

Outra forma de expor a História da Matemática é aquela que trata separadamente da evolução de algum assunto específico dentro da Matemática. Esse tipo de livro tem características importantes do ponto de vista de sua utilização didática. Conforme vimos, Smith aponta a possível aplicação pedagógica como uma das razões que o levaram a compor uma obra dupla, parte cronológica e parte por assunto. Segundo ele, a História da Matemática

tornou-se reconhecida como uma matéria importante na formação de professores e na educação liberal de alunos em faculdades e colégios, mostrando, como é de fato, a Matemática em constante progresso, em vez de ser uma massa estática de conhecimento. Através da consideração da História da Ciência o aluno chega a apreciar o fato de que a Matemática tem-se ajustado continuamente às necessidades humanas, ambas materiais e intelectuais ${ }^{184}$.

Com esse objetivo didático, Smith organiza o conteúdo no seu segundo volume tratado-o por tópicos. Pretende assim que o professor, ao ensinar Aritmética, por exemplo, obtenha em três ou quatro capítulos um relato do crescimento daquele assunto: como surgiram as operações, etc. O mesmo com relação à Geometria e a outros tópicos de Matemática elementar, conforme podemos verificar na sua relação de conteúdo.

\section{Smith: História da Matemática}

\begin{tabular}{|lr|}
\hline \multicolumn{2}{|c|}{ SMITH, David Eugene. History of } \\
Mathematics. Boston, Ginn and Co., 1923. V. \\
II, 725 páginas
\end{tabular}

Dentro de cada capítulo Smith faz ainda uma divisão em sub-ítens que especificam melhor o assunto cuja História vai relatar. Assim, por exemplo, Smith subdivide o Capítulo 2 em:

\section{Capítulo 2:}

\section{Logística dos Números Naturais}

\begin{tabular}{|lr|}
\hline 1. Operações Fundamentais & 32 \\
2. Leitura e Escrita de Números & 36 \\
3. Adição & 88 \\
4. Subtração & 94 \\
5. Multiplicação & 101 \\
6. Divisão & 128
\end{tabular}

\footnotetext{
183 GROZA, Vivian Shaw. A Survey of Mathematical Elementary Concepts and their Historical Development. New York, Holt, Rinehart and Winston, 1968, 327 p., Prefácio, p. viii

184 SMITH, David Eugene. History of Mathematics. 2 v. Boston, Ginn and Co., 1923. 725 p., V. II, Preface, p. iii
} 


\section{Raízes 144 \\ 8. Checagem de Operações \\ 151}

A grande abrangência dessa obra de Smith ultrapassa o conteúdo padrão de um currículo de Matemática elementar. Apesar de ir apenas da Aritmética elementar até o Cálculo, o que de certo modo coincide com os limites de muitos currículos elementares, é em termos de profundidade que sai bastante desses limites. A luz histórica que lança sobre um tópico específico amplia enormemente sua capacidade de repercussão dentro do currículo. Um assunto aparentemente sem brilho, como por exemplo a apresentação dos símbolos matemáticos das operações fundamentais $(+,-, x,:)$, ganha em vinte páginas todo um colorido histórico que podemos utilizar em várias aulas ${ }^{185}$. Essa abundância de dados faz com que a utilização dessa obra de Smith em sala de aula requeira atenção especial do professor, a fim de que não entre em desvios, superdimensionando o tratamento de certos tópicos em razão das curiosidades apresentadas. Esse perigo porém parece ser menor que o de não haver em todo um curso elementar de Matemática, nenhuma menção ao desenvolvimento histórico dos assuntos estudados.

\section{Sanford: Uma Breve História da Matemática}

\begin{tabular}{|l|r|}
\hline \multicolumn{2}{|c|}{ SANFORD, Vera. A Short History of } \\
Mathematics. New York, Houghton Mifflin, \\
1930. 402 p. \\
\hline \multicolumn{2}{|c|}{ Conteúdo: } \\
\hline Homens que fizeram a & 1 \\
Matemática & 72 \\
Aritmética & 116 \\
Matemática comercial & 141 \\
Álgebra & 204 \\
Problemas verbais & 227 \\
Geometria prática & 252 \\
Geometria demonstrativa & 291 \\
Trigonometria & 302 \\
Geometria analítica & 308 \\
Cálculo & 329 \\
Teoria dos números & \\
Instrumentos de Cálculo & 338 \\
Pesos e medidas & 353 \\
O lugar da Matemática no \\
Currículo Escolar \\
\hline
\end{tabular}

Uma orientanda de Smith, Vera Sanford, produziu em 1930 um livro de História da Matemática por assunto muito especial. Mantendo a precisão científica de Smith, Vera Sanford aproxima-se mais da Matemática elementar tal como aparece no dia-a-dia do Professor. O próprio Smith considera a vocação didática dessa obra, na Introdução por ele escrita:

O propósito de uma obra como essa da Dra. Sanford é claro: é mostrar a Matemática elementar - que podemos considerar como indo até o Cálculo - como um rio de água corrente em vez de uma poça estagnada; um rio que foi constantemente alimentado pelas fontes puras através dos séculos do seu progresso; um rio que, no entanto, tornou-se freqüentemente saturado com sedimento de modo a indispor suas águas para uso humano; e um rio que precisa de filtragem constante se deve ser bom para uso no futuro ${ }^{186 .}$

Conforme vemos na sua relação de conteúdo, o livro inicia com uma original vista de olhos na evolução da Matemática ao longo do tempo, num capítulo intitulado

185 Cf. Ibid., p. 395

186 SANFORD, Vera. A Short History of Mathematics. New York, Houghton Mifflin, 1930. 402 p., Introduction 
Homens que Fizeram a Matemática. Em setenta e uma páginas, Sanford fornece a estrutura mínima cronológica sobre a qual irá construir sua História por assunto. Os assuntos que escolhe relatar são praticamente os mesmos de Smith, mas ela se atém mais estritamente ao que é de interesse para quem pretenda utilizar as informações que fornece com fins didáticos. Smith preocupa-se mais com a abrangência; Sanford tem um olhar mais concreto e objetivo para aquilo que interessa ao Professor de Matemática elementar. Seu livro trás muitas ilustrações, mapas, retratos de matemáticos, fotos de documentos antigos, reproduções de fontes arqueológicas, trechos de manuscritos originais, etc. Isso tudo também pode ser útil para fins didáticos. Ao falar da Teoria dos Números, por exemplo, Sanford mostra a reprodução de uma página do manuscrito de Boécio sobre Números Figurados, e um retrato de Fermat ${ }^{187}$.

A objetividade do texto de Vera Sanford pode às vezes torná-lo um pouco direto demais. É o caso das tabelas que apresenta, por exemplo ao expor as variantes do sinal de raiz ${ }^{188}$. Eis um trecho da tabela:

\begin{tabular}{|c|c|l|l|l|}
\hline 1521 & Rudolff & & & \\
\hline 1553 & Stifel & & & \\
\hline 1585 & Stevin & & & \\
\hline 1707 & Newton & & & \\
\hline
\end{tabular}

Talvez fosse mais útil uma explicação pormenorizada de cada símbolo, com razões da adoção dos mesmos por cada autor. Não faltava por certo erudição e material para Sanford ter alongado a discussão em torno dessa tabela e de outras, mas se preferiu ser sintética pode ser porque não viu motivação histórica suficientemente relevante por trás da adoção desses símbolos, ou porque confiava na capacidade inventiva e aprofundadora do Professor. Pois basta uma relação como a colocada acima para suscitar todo um mundo de abordagens interessantes que podem dotar uma aula de ritmo de descoberta muito produtivo.

Uma palavra ainda pode ser dita sobre o último capítulo de Vera Sanford, intitulado O Lugar da Matemática no Currículo Escolar. Obviamente, as sete páginas do capítulo não são suficientes para analisar historicamente a Matemática enquanto disciplina escolar. Mas a importância desse capítulo está justamente na sua posição dentro do livro como um fecho de todo um levantamento histórico dos diversos assuntos que compõem a Matemática elementar. Apesar de ser muito sintético, logra de fato apresentar resumidamente o papel que a Matemática desempenhou na Educação formal no passado, formando uma base para a discussão das tendências atuais do presente ${ }^{189}$. Ou seja, a colocação de uma tal discussão sobre o papel da Matemática num contexto histórico é por si só uma idéia de grande valor. Ainda que Sanford não a tenha levado às últimas conseqüências, fornece a quem queira interessar-se linhas de pesquisa muito florescentes.

Uma vista de olhos na listagem do conteúdo desse capítulo pode ser útil agora:

\begin{tabular}{|l|}
\hline \multicolumn{1}{|c|}{ Capítulo XIV } \\
\hline O Lugar da Matemática no Currículo Escolar \\
\hline No Mundo Antigo: \\
\hline Matemática na Educação Grega \\
\hline Matemática na Educação Romana \\
\hline Escolas e Universidades da Europa: \\
\hline A Idade Média \\
\hline As Universidades \\
\hline O Estudo da Geometria \\
\hline Escolas e Faculdades na América: \\
\hline Matemática Elementar nas Faculdades \\
\hline Exigências de Exames Vestibulares \\
\hline
\end{tabular}

\footnotetext{
187 Ver pp. 331-6

188 Cf. p. 159

189 Cf. p. 378
} 
Matemática Fora das Universidades dos padrões típicos de livros de História da Matemática por assunto, mas que representa uma alternativa valiosa dentro dessa categoria. O livro consiste numa ampliação do conteúdo de um curso de um semestre ministrado pela autora para alunos de graduação em Educação. Como a autora explica no Prefácio,

o objetivo do curso é familiarizar o aluno com os vários ramos da Matemática e desenvolver uma apreciação e compreensão da relação entre a Matemática e o mundo moderno. Os conceitos que são apresentados nas escolas elementares atuais são cobertos em profundidade, e são relacionados com o fundamento histórico a partir dos quais se desenvolveram ${ }^{190}$. 


\section{Groza: Uma Visão Geral dos Conceitos Elementares de Matemática e seu Desenvolvimento Histórico}

\begin{tabular}{|c|c|}
\hline $\begin{array}{c}\text { GROZA, Vivian Shaw. A S } \\
\text { Mathematical Elementary Conce } \\
\text { Historical Development. New } \\
\text { Rinehart and Winston, } 1968\end{array}$ & $\begin{array}{l}\text { their } \\
\text { It, }\end{array}$ \\
\hline $\begin{array}{c}\text { Conteúdo: } \\
\end{array}$ & \\
\hline $\begin{array}{l}\text { Período Pré-Histórico } \\
\text { Contagem } \\
\text { Conjuntos }\end{array}$ & $\begin{array}{r}1 \\
3 \\
16\end{array}$ \\
\hline O Período Oriental Antigo & 33 \\
\hline $\begin{array}{l}\text { Sistemas de Numeração } \\
\text { Bases Arbitrárias } \\
\text { Cálculo Antigo: } \\
\text { Pré-Álgebra } \\
\text { Pré-Geometria }\end{array}$ & $\begin{array}{l}37 \\
58\end{array}$ \\
\hline $\begin{array}{l}\text { Período Grego } \\
\text { Lógica } \\
\text { Sistemas Matemáticos }\end{array}$ & $\begin{array}{r}95 \\
106 \\
126\end{array}$ \\
\hline $\begin{array}{l}\text { Geometria Euclidiana } \\
\text { Elementar }\end{array}$ & 147 \\
\hline Aritmética Grega & 181 \\
\hline O Período Hindu-Arábico- & 193 \\
\hline $\begin{array}{l}\text { Europeu } \\
\text { O Desenvolvimento da } \\
\text { Aritmética }\end{array}$ & 211 \\
\hline $\begin{array}{l}\text { Álgebra } \\
\text { Probabilidade, } \\
\text { Geometria }\end{array}$ & $\begin{array}{l}233 \\
266\end{array}$ \\
\hline
\end{tabular}

Portanto, de uma maneira bastante definida, essa obra apresenta-se com uma proposta radical de ensinar Matemática usando a História da Matemática com um recurso pedagógico. Suas razões para isso estão resumidas no seu Prefácio:

Primeiro, a História serve como um fio unificador ligando vários tópicos de Matemática num todo que é significativo para 0 aluno. 0 arranjo também serve para ajudar o aluno a apreciar o significado cultural dos desenvolvimentos da Matemática e talvez motivá-lo através do relacionamento da Matemática com áreas que são provavelmente mais confortáveis e familiares para ele ${ }^{191}$.

Groza faz portanto um uso explícito da História da Matemática para ensinar tópicos elementares de Matemática. Para cada assunto que quer apresentar, constrói um pano de fundo histórico que Ihe serve de envoltório didático, tornando-o mais acessível ao aluno. Além disso, ainda toma a liberdade de construir o próprio programa do seu curso de acordo com certa cronologia histórica. Essa dupla utilização da História da Matemática, que faz essa obra bastante original e instrutiva, talvez pareça situá-la como um tipo intermediário entre a Cronologia e os livros Por Assunto. Mas na verdade ela é propriamente do último tipo, pois seus critérios não são rigorozamente cronológicos. Como a própria autora afirma,

uma vez que um aluno não familiarizado com a matéria da Matemática teria grande dificuldade em entender uma História Cronológica da Matemática, algumas alterações foram feitas na ordem histórica. Alguns tópicos da Matemática moderna são discutidos em épocas mais antigas por várias razões. $O$ assunto pode ajudar 0 aluno a entender melhor 0 material desenvolvido num período anterior, ou o tópico pode ser fundamental para

191 Id. Ibid. 
a discussão do material seguinte a esse tópico, ou o tópico pode completar a unidade sobre um determinado assunto.

Por exemplo, a Teoria elementar dos Conjuntos é apresentada durante 0 período pré-histórico porque 0 conceito de Conjunto é base do de Número e porque a Teoria dos Conjuntos forma um fundamento para outros ramos da Matemática ${ }^{192}$.

Para Groza, mais importante que a seqüência histórica completa da evolução da Matemática, interessam as pequenas contextualizações históricas para cada assunto. Por isso não tem escrúpulos em mencionar a Teoria dos Conjuntos quando está falando das origens pré-históricas da idéia de Número, apesar dessa teoria ter sido criada por Georj Cantor no final do século $\mathrm{XIX}^{193}$. Tomados independentemente da seqüência em que aparecem no livro, no entanto, os tópicos são tratados muito bem, individualmente. A seqüência pseudo-cronológica em que estão situados, apesar de artificial, parece ser eficaz também, segundo as razões expostas pela autora no Prefácio. Os resultados de suas experiências com essa abordagem histórica do ensino da Matemática foram bastante positivos, conforme ela afirma no trecho citado na epígrafe deste capítulo.

192 Ibid., Preface, p. viii

193 Cf. Ibid., p. 16 


\subsection{Outros}

Falando de maneira lógica, é imperioso constatar que nenhum estudo histórico pode dar-nos a certeza de haver esgotado todo o material documentário existente.

Marrou $^{194}$

Dos muitos tipos de livros já escritos sobre História da Matemática, e dos inúmeros outros que podem surgir devido à quase inesgotável quantidade de aspectos que assume a evolução histórica dessa Ciência milenar, escolhemos destacar três dos quais acabamos de falar: Cronologias, Biografias e Por Assunto. Além desses três grandes campos, existem muitos outros tipos de livros que olham algum setor da História da Matemática através de um prisma determinado. Vamos avaliar alguns livros de outros tipos, que pareceram-nos relevantes de acordo com os fins a que nos propomos.

\section{Cajori: Uma História da Notação Matemática}

\begin{tabular}{|l|}
\hline \multicolumn{1}{|c|}{$\begin{array}{l}\text { CAJORI, Florian. A History of Mathematical Notations. } \\
\text { Chicago, The Open Court, 1928. } 2 \text { v. (Volume 1: Notations } \\
\text { in Elementary Mathematics. 451 p.) }\end{array}$} \\
\hline \multicolumn{1}{|c|}{ Conteúdo: } \\
\hline \begin{tabular}{l} 
Símbolos Numéricos e Combinações de \\
Símbolos \\
(Relação Histórica dos Numerais de Diversas \\
$\begin{array}{l}\text { Civilizações. Há todo um estudo sobre os } \\
\text { nossos numerais, com muitas teorias sobre } \\
\text { sua origem e desenvolvimento) }\end{array}$ \\
\hline $\begin{array}{l}\text { Símbolos em Aritmética e Álgebra } \\
\text { A. Símbolos de Autores Individuais } \\
\text { (Descrição, com muitas ilustrações originais, } \\
\text { dos símbolos desenvolvidos ou } \\
\text { popularizados pelos principais matemáticos } \\
\text { da História) }\end{array}$ \\
\hline $\begin{array}{l}\text { B. Uso de Notação } \\
\text { (Contém a História de todos os sinais de }\end{array}$ \\
operações e de relações matemáticas \\
elementares)
\end{tabular} \\
\hline $\begin{array}{l}\text { Símbolos em Geometria } \\
\text { (Relata a História dos símbolos usados em } \\
\text { Geometria) }\end{array}$ \\
\hline
\end{tabular}

Um aspecto importante da Matemática que influencia muito seu ensino é sua notação simbólica. Existe uma linguagem própria da Matemática, criada e aperfeiçoada pelo homem ao longo dos tempos. Novos símbolos são criados e outros caem em desuso. Para Florian Cajori, o surgimento e eventual declínio de certos símbolos podem constituem em muitos casos uma História interessante ${ }^{195}$. Cajori então decidiu escrever sua magnífica obra, cujo Volume Um, Notações em Matemática Elementar, apresenta um material riquíssimo que pode ser utilizado de mil modos pelo Professor em sala de aula. O Volume Dois, Notações em Matemática Superior, seria mais endereçado a Pesquisadores em Matemática interessados na questão da simbologia.

A relação de conteúdo do Volume Um é muito minuciosa. Aqui trazemos apenas um apanhado dos principais tópicos abordados no livro. Em todo o livro, encontramos mais de cem ilustrações muito interessantes, documentando a utilização de um

\footnotetext{
194 MARROU, Henri-Irénée. Sobre o Conhecimento Histórico. Tradução de Roberto Cortes de Lacerda. Rio de Janeiro, Zahar Editores, 1978, 265 p., p. 66

195 CAJORI, Florian. A History of Mathematical Notations. Chicago, The Open Court, 1928. 2 v. V. 1: Notations in Elementary Mathematics. 451 p., p. 1
} 
determinado símbolo em épocas e civilizações passadas. Evidentemente, essa obra de Cajori presta-se mais a consultas específicas que a um uso intenso. Suas aplicações didáticas são, entretanto, muito amplas, pois todo tópico de Matemática envolve alguma simbolização. O choque que essa carga simbólica causa nos alunos pode muito bem ser aliviado com uma abordagem de construção ou reconstrução de símbolos, à imitação da construção histórica real. Os símbolos matemáticos podem assim perder o aspecto obscuro que às vezes adquirem, para se tornarem parte integrante da linguagem natural de expressão matemática dos alunos.

\section{Aaboe: Episódios da História Antiga da Matemática.}

\begin{tabular}{|c|c|c|}
\hline \multicolumn{3}{|c|}{$\begin{array}{l}\text { AABOE, Asger. Episódios da História Antiga da Matemática. } \\
\text { Trad. de João Pitombeira de Carvalho. Rio de Janeiro, } \\
\text { Sociedade Brasileira de Matemática, 1984. } 170 \text { p. }\end{array}$} \\
\hline \multicolumn{3}{|c|}{ Conteúdo: } \\
\hline 1 & $\begin{array}{l}\text { A Matemática Babilônia } \\
\text { (Trata do sistema numérico } \\
\text { mesopotâmico,interpretando algumas tabletas em } \\
\text { escrita cuneiforme) }\end{array}$ & 9 \\
\hline 2 & $\begin{array}{l}\text { A Matemática Grega Antiga e a Construção de } \\
\text { Euclides para o Pentágono Regular } \\
\text { (Fala de Os Elementos de Euclides, mencionando } \\
\text { a Matemática antes dele e fazendo uma breve } \\
\text { análise das traduções de Os Elementos) }\end{array}$ & 43 \\
\hline 3 & $\begin{array}{l}\text { Três exemplos de Matemática Arquimediana } \\
\text { (A vida e as obras de Arquimedes são aqui } \\
\text { relatadas sucintamente, com destaque a três } \\
\text { estudos: } \\
\text { - A Trissecção do ângulo } \\
\text { - A Construção do Heptágono Regular } \\
\text { - O Cálculo do Volume e da Superfície da Esfera) }\end{array}$ & 94 \\
\hline 4 & $\begin{array}{l}\text { A Construção, por Ptolomeu, de uma Tábua } \\
\text { Trigonométrica } \\
\text { (Narra a vida e a obra de Ptolomeu, destacando } \\
\text { seu Almagesto e a construção da sua Tábua de } \\
\text { Cordas) }\end{array}$ & 127 \\
\hline
\end{tabular}

Em contraste com as obras de grande porte sobre História da Matemática, surgiram alguns livros que dedicam-se a explorar tópicos específicos dessa História, como a de Aaboe. Reduzindo o âmbito de estudo a quatro aspectos da Matemática antiga, o autor logra obter uma maior pormenorização descritiva, com uma conseqüente melhor compreensão da Matemática envolvida, como ele mesmo descreve:

Selecionei quatro episódios da História da Matemática antiga, e os tratei detalhadamente, com comentários que transmitam noção do contexto apropriado. Como principio orientador de minha escolha de tópicos, usei primeiramente o de que um conteúdo matemático deveria estar ao alcance de um estudante com conhecimento da Álgebra e da Geometria do segundo grau ${ }^{196}$.

A escolha de Aaboe insere seu livro dentro do escopo próprio da Matemática elementar, sendo portanto de grande interesse e utilidade para o Professor. A Matemática envolvida nos episódios que relata está bem trabalhada e, no final de cada item, há problemas referentes ao tema em questão. Seguramente essa abordagem histórica torna o conteúdo matemático muito mais acessível e, o que é mais importante, cheio de significado.

196 AABOE, Asger. Episódios da História Antiga da Matemática. Trad. de João Pitombeira de Carvalho. Rio de Janeiro, Sociedade Brasileira de Matemática, 1984. 170 p., p. 6 


\section{Lauand: Educação, Teatro e Matemática Medievais.}

\begin{tabular}{|rr|}
\hline \multicolumn{2}{|c|}{$\begin{array}{l}\text { LAUAND, Luiz Jean. Educação, Teatro e Matemática } \\
\text { Medievais. São Paulo, Perspectiva/EDUSP, 1986. 117 p. }\end{array}$} \\
\hline \multicolumn{1}{|c|}{ Conteúdo: } \\
\hline $\begin{array}{l}\text { Introdução: } \\
\text { Atualidade da Pedagogia Medieval }\end{array}$ \\
\hline I $\begin{array}{l}\text { Teatro Medieval: } \\
\begin{array}{l}\text { A Peça "Sabedoria" de Rosvita de } \\
\text { Gandersheim }\end{array}\end{array}$ \\
\hline II $\begin{array}{l}\text { Mestre e Aluno no Século VIII: } \\
\text { O "Diálogo entre Pepino e Alcuino" }\end{array}$ \\
\hline III & $\begin{array}{l}\text { Matemática e Ensino de } \\
\text { Matemática nos Primeiros Séculos } \\
\text { Medievais }\end{array}$ \\
\hline
\end{tabular}

Dentro da História da Matemática há uma infinidade de assuntos, cada um dos quais poderia gerar um livro. Esse universo amplia-se ainda mais se consideramos a relação entre a História da Matemática e a História da Cultura, das Artes e das Ciências em geral. Exemplo desse difícil contraponto encontramos nessa obra de Lauand, que trata de textos teatrais, educacionais e matemáticos de uma época determinada, tecendo comentários e observações em torno dos elementos de ligação entre essas manifestações humanas. A etapa matemática em questão fica então muito mais fácil de ser compreendida, dentro do contexto das outras manifestações culturais da mesma época.

Assim, por exemplo, estão intimamente ligados o caráter popular do teatro típico medieval ${ }^{197}$, o processo pedagógico então em voga, baseado no diálogo educativo, permeado de adivinhas ${ }^{198}$, e o método de resolução de problemas matemáticos através de tentativas $^{199}$.

Esse resgate da cultura genuína das épocas passadas, através do recurso aos originais, permite um enorme enriquecimento do currículo matemático. Surgem então possibilidades muito amplas para o tratamento didático de diversos temas. Por exemplo, a resolução de problemas pelo método medieval, sem uso de letras como incógnitas algébricas, é um interessante meio de desenvolver o raciocínio matemático, evitando os prejuízos de uma simbolização excessiva.

\section{Wilder: Evolução dos Conceitos Matemáticos}

\begin{tabular}{|ccr|}
\hline $\begin{array}{l}\text { WILDER, Raymond Louis. Evolution of } \\
\text { Concepts. New York, John Wiley, 1973. 216 p. }\end{array}$ \\
\hline \multicolumn{3}{|c|}{ Conteúdo: } \\
\hline 1 & Introdução & 1 \\
2 & Noções Preliminares & 17 \\
3 & Evolução Antiga do Número & 32 \\
4 & Evolução da Geometria & 77 \\
5 & Os Números Reais. A Conquista do Infinito & 108 \\
6 & Os Processos de Evolução & 144 \\
& Aspectos da Evolução da Matemática & 176 \\
\hline
\end{tabular}

Essa obra de Wilder poderia estar entre os livros de História da Matemática por assunto, se nos baseássemos apenas na relação de conteúdo exposta

\footnotetext{
197 LAUAND, Luiz Jean. Educação, Teatro e Matemática Medievais. São Paulo, Perspectiva/EDUSP, 1986. 117 p., p. 39

198 Cf. Ibid., p. 73

199 Cf. Ibid., p. 105
} 
acima. Mas o ponto de vista de Wilder, ao olhar para a História da Matemática, é diferente: ele não visa relatar a história de cada assunto abordado, mas descobrir, no estudo de sua evolução, as principais forças que influenciam o desenvolvimento das idéias matemáticas.

É desse modo que ele chega a elaborar, ao final do livro, uma Carta Magna sobre a pesquisa em Matemática, e que constrói também a tabela de estágios na evolução da idéia de Número. Nesse nível de aprofundamento, o livro pode ser considerado único, consistindo em leitura obrigatória para quem se interesse em estudar o desenvolvimento da Matemática. Do ponto de vista do seu uso didático, a linguagem e as discussões estão num nível acadêmico talvez pouco acessível, e a carência de pormenores históricos também desaconselha seu uso como fonte de conhecimento sobre a História da Matemática, de uma maneira ampla.

\section{Alguns Livros com Referências Históricas}

Alguns livros, sem ser propriamente de História da Matemática, trazem interessantes comentários históricos de grande utilidade. Comentaremos aqui, de passagem, alguns deles.

COSTA, Manuel Amoroso. As Idéias Fundamentais
da Matemática e Outros Ensaios. $3^{\mathrm{a}}$ ed. São Paulo,
Convívio/EDUSP, 1981. 330 p.

O ensaio As Idéias Fundamentais da Matemática, datando de 1929 e contido nessa edição mais recente, traz ótimas referências históricas. Principalmente o Item VI - A Evolução Histórica da Noção de Número (pp. 217-224) - é de grande valor, em parte pela abrangência que consegue obter em oito sintéticas páginas. Outros itens são também interessantes, trazendo muitas vezes esboços históricos completos do assunto que pretendem abordar.

CARAÇA, Bento de Jesus. Conceitos
Fundamentais da Matemática. $9^{a}$ ed. Lisboa, Sá da
Costa, 1989. 318 p.

Escrito em 1941, esse livro opta por expor as idéias matemáticas segundo a maneira em que foram construídas historicamente. Nesse sentido, não só os itens propriamente históricos são úteis ${ }^{200}$, mas todos os outros também, pois seu modo de expor os conceitos é sempre imbuído de sentido e perspectiva históricos.

HERSH, Reuben \& DAVIS, Philip J. A Experiência
Matemática. $4^{\mathrm{a}}$ ed. Trad. de João Bosco
Pitombeira. Rio de Janeiro, Francisco Alves, 1989.
481 p.

Com uma estrutura interna bastante livre, os autores conseguem abordar temas matemáticos e históricos importantes, discutindo o que é o fazer-se da Matemática. Tomam muitos exemplos tirados da História da Matemática, dentro da perspectiva de olhar a Matemática a partir de dentro 201.

200 Como o Capítulo IV da $1^{\text {a }}$ Parte: Um Pouco de História (pp. 64-82) e o Capítulo IV da $2^{\text {a }}$ Parte: Excursão Histórica e Filosófica (pp. 179-210)

201 Dos mesmos autores, ver também O Sonho de Descartes. Trad. de Márcio C. Moura. Rio de Janeiro, Francisco Alves, 1988. 335 p. Nesse livro procuram mostrar a Matemática pelo lado de fora, isto é, analizando o impacto de sua aplicação ao mundo exterior a ela, o que comumente se chama de Matemática Aplicada. Por isso traz menos referências históricas que o anterior. 


\section{Capítulo 3 O Valor Didático da História da Matemática}

Nesse Capítulo 3 iremos apresentar três componentes principais do valor da História da Matemática como recurso pedagógico. No Item 1 abordaremos a História da Matemática enquanto fonte da lógica da Matemática em construção. No Item 2 iremos analisar o papel da História da Matemática como instrumento para a superação da dicotomia entre técnica e significado no ensino elementar da Matemática.

No último item, indicaremos como o recurso à História propicia uma visão de totalidade do conhecimento matemático que é fundamental para uma melhor compreensão de certos aspectos que isoladamente parecem carecer de sentido, em particular no que se refere à questão das aplicações práticas do conteúdo da Matemática elementar.

\subsection{História da Matemática e Lógica da Matemática em Construção}

Que grande discussão que há sobre o ponto elementar da lógica como julgar a verdade ou falsidade de uma frase complexa do tipo "Se é de dia, então há luz": Diodoro tem uma opinião, Filo tem outra e Crisipo tem uma terceira.

Cícero ${ }^{202}$

0 pensamento e sua expressão não são de igual natureza. A linguagem é para o pensamento um corpo estranho a que lhe custa trabalho acomodar-se. A palavra tem no tempo, digamos, crônico, um começo e um fim: a aula do professor começará às dez e terminará às onze, mas o pensamento que sua palavra formula não começa nem acaba com a aula, que mergulha no pensamento, por assim dizer, e o pensamento transborda por todos os lados.

Gilson 203

Um importante componente do valor didático da História da Matemática é sua relação com a lógica, a qual se encontra ligada de maneira intrínseca ao ensino da Matemática elementar. Para se compreender isso, é necessário observar inicialmente que noções como lógica e demonstração não são exclusivas da linguagem matemática, mas possuem uma aplicação muito ampla. Essa noção ampla é elucidadora dos processos de ensino e aprendizagem.

Não pretendemos de modo algum reduzir todo o complexo processo de ensino e aprendizagem a mera questão de transmissão e recepção de informação. Mas não se deve ignorar que o diálogo educativo necessita de uma comunicação eficiente. O papel da linguagem e da lógica no ensino de Matemática é de alta relevância, e obter um encadeamento lógico adequado para o ensino implica a construção de um ensino mais significativo, motivador e eficaz.

Naturalmente, o termo lógica está sendo aqui utilizado em sentido amplo. Já na década de cinqüenta o filósofo suíço Innocentius Marie Bochenski, ao escrever sobre os métodos do pensamento, ressaltava a importância de compreender a ampla significação do termo lógica:

202 CícERO. Academia Priora. ii. 143. Apud KNEALE, Willian \& KNEALE, Martha. O Desenvolvimento da Lógica. 1a ed. Trad. de M. S. Lourenço. Lisboa, Fundação Calouste Gulberkian, 1972, 770 p., p. 118

203 GILSON, Étiene. Lingüística y Filosofía: Ensaio sobre las Constantes Filosóficas del Lenguaje. Versión espanola do F. Béjar Furtado. Madrid, Editorial Gredos, 1974. 334 p., p. 113 


\section{- mais ambíguas que a palavra "lógica"204 \\ Poucas palavras há - inclusive na terminologia filosófica \\ Em seguida descrevia alguns significados de lógica relacionados com o} raciocínio. Destacava três significados principais, alertando para o fato de que sua confusão pode trazer conseqüências lamentáveis ${ }^{205}$ : a lógica enquanto conjunto de leis do raciocínio silogístico, muitas vezes chamada de Lógica Formal; a lógica enquanto questionadora da própria validade dessas leis, que se pode chamar de filosofia da lógica; e a lógica enquanto aplicação das leis do raciocínio aos diversos campos do saber, que pode ser chamada, segundo Bochenski, de metodologia.

Prossegue explicando Bochenski que a palavra metodologia vem do grego e significa literalmente "percorrer um caminho"206. A lógica, considerada nesse sentido, possui uma aplicação ampla que muitas vezes é causa de confusões. Não se pode dizer que exista uma única lógica, pois para cada meta a ser atingida pode haver um caminho a percorrer, uma metodologia: assim, temos uma metodologia para cada ciência, e para cada ação a ser desenvolvida. Não só existem caminhos e metodologias diversas para cada ramo do conhecimento, como também uma mesma ciência apresenta relações lógicas de diversos níveis, conforme seu estágio de desenvolvimento. Num estágio avançado de sistematização, a ordenação lógica das proposições já formuladas pela Ciência é dita formal. Ciência formalizada é Ciência organizada segundo a Lógica Formal. Como afirma Bochenski:

A lógica, e precisamente a Lógica Formal, constitui, pois, o marco indispensável da Ciência assim entendida, que sempre supõe a lógica 207 .

Porém, considerando a Ciência não já como conhecimento sistematizado, mas ainda em fase de elaboração, investigação, pesquisa, construção, nela encontramos outro nível de relações lógicas, que não a Lógica Formal. A lógica, no seu sentido mais amplo, está presente em toda pesquisa, embora isso não signifique que o pesquisador utilize a Lógica Formal e Metodologia de Ciência Formalizada desde o início da pesquisa. Como afirma Bochenski, tanto uma como outra não são característicos da Ciência em construção:

Sabemos de sobra que nos estágios iniciais de uma Ciência o conhecimento de ambas não é indispensável e que bastam as disposições lógicas naturais ${ }^{208}$.

Uma Ciência em fase de construção admite portanto uma certa metodologia, ou, se se quiser, uma certa lógica, que Bochenski chama de lógica natural, a qual é distinta da lógica que, posteriormente, tal ciência irá apresentar, quando estiver sistematizada. Os princípios da lógica são abstraídos da Ciência e formulados, não na fase inicial da construção da Ciência, mas quando esta última já se encontra em pleno desenvolvimento.

Com relação à Ciência Matemática, os estudos históricos deixam muito clara essa distinção entre a forma lógica inicial, presente nas origens da Matemática, e sua posterior e paulatina sistematização. Parece importante para a compreensão da distinção dessas etapas lógicas estudar a própria origem da Lógica Formal. Nas páginas iniciais de $O$ Desenvolvimento da Lógica 209 , de Martha e William Kneale, encontramos um estudo interessante sobre as origens históricas da Lógica Formal, com amplas referências à formalização da Matemática, e em particular da Geometria:

Sabe-se que os egípcios descobriram empiricamente algumas verdades de geometria(...), e a designação de "geometria", que inicialmente significa o mesmo que "medida da terra", mostra o que se pensava desta Ciência quando ela foi introduzida na Grécia. A grande realização dos gregos foi substituir esse estudo empírico por uma Ciência demonstrativa e a priori210.

\footnotetext{
204 BOCHENSKI, Innocentius Marie. Los Metodos Actuales del Pensamiento. Traducción de Raimundo Drudis Baldrich. 2a ed. Madrid, Rialp, 1958. 278 p., p. 29

205 Ibid., p. 31

206 Ibid., p. 32

207 Ibid., p. 36-7

208 Ibid., p. 38

209 KNEALE, Willian \& KNEALE, Martha. O Desenvolvimento da Lógica. 1a ed. Trad. de M. S. Lourenço. Lisboa, Fundação Calouste Gulberkian, 1972, 770 p.

210 lbid., p. 25
} 
Atribui-se a Tales de Mileto (624-548 aC) a demonstração do primeiro teorema de geometria, mas é na escola de Pitágoras de Samos (580-500 aC) que parece ter tido início o estudo sistemático dessa Ciência. Entretanto, o modo de apresentar a geometria na época de Tales e Pitágoras não seguia a mesma metodologia formal que encontramos numa obra posterior, como Os Elementos de Euclides, que data do começo do século III aC. Em Os Elementos, a geometria aparece já estruturada com uma Ciência dedutiva:

Em primeiro lugar, certas proposições têm que ser tomadas como verdadeiras sem demonstração; em segundo lugar, todas as outras proposições têm que ser derivadas destas; em terceiro lugar, a derivação tem que ser feita sem recorrer a conceitos geométricos que não figurem nas proposições primitivas; por outras palavras, a derivação tem que ser formal ou independente do tópico particular discutido em geometria 211 .

Insistimos em que essa estrutura formal não era utilizada desde o início. Ao contrário, supõe-se que para os primeiros geômetras gregos bastava qualquer processo que lhes permitisse ver a "verdade" de um teorema. No caso, por exemplo, do Teorema de Pitágoras, a demonstração que encontramos em Euclides é bastante complicada. Embora talvez os primitivos pitagóricos conhecessem os mesmos teoremas preliminares àquela demonstração, não se supõe que os tenham elaborado na ordem que encontramos em Euclides. O mais natural será que a primeira demonstração do Teorema de Pitágoras fosse a construção de uma figura na qual se pudesse "ler" o teorema.

Infelizmente, não podemos estudar a fundo o modo pelo qual os gregos foram reconhecendo as exigências da demonstração, pois o fato é que não dispomos de qualquer obra completa de geometria grega anterior aos Elementos de Euclides ${ }^{212}$. Isso não significa que a Geometria já nasceu organizada axiomaticamente tal como Euclides nos apresenta. Acontece que quando Euclides escreveu sua obra, no começo do século III aC, já se tinha tornado claro para os geômetras o ideal de demonstração. Esse ideal, bem como as bases da Lógica Formal, dos princípios e leis da inferência válida, do raciocínio silogisticamente estruturado, foram estabelecidos de modo marcante por Aristóteles (384-322 aC). Kneale e Kneale acrescentam:

Quando os escritos de Aristóteles foram reunidos pelos seus alunos depois da sua morte em 322 , uma série dos seus tratados sobre o raciocínio foi agrupada e a coleção acabou por se chamar Organon, ou instrumento da Ciência. A palavra "lógica" só adquiriu o seu sentido moderno 500 anos mais tarde quando foi usada por Alexandre de Afrodisias; mas o âmbito da investigação, mais tarde chamada lógica, foi determinado pelo conteúdo do Organon ${ }^{213}$.

Essa organização lógica feita por Aristóteles significou o auge de um processo de discussão de séculos acerca dos princípios da inferência válida. Nessa discussão teve papel decisivo o interesse grego pela Matemática pura. A linguagem Matemática não é a única que exige coerência lógica. Mas no tempo em que se deu a gênese da Lógica Formal na Grécia, para ela é que se voltaram esses primeiros lógicos, conforme relatam Kneale e Kneale:

Podemos distinguir três tipos diferentes de linguagem nos quais se procura ou exige demonstração. Em Matemática pura pretendemos demonstrar verdades abstratas e a priori, em metafísica pretendemos demonstrar proposições muito gerais sobre a estrutura do universo e na linguagem de todos os dias, especialmente na linguagem política e jurídica, procuramos demonstrações de proposições contingentes. Destas três apenas a Matemática corresponde à descrição de Aristóteles do funcionamento da demonstração e além disso é esta quem fornece o maior número de exemplos de demonstrações ${ }^{214}$.

Isso explica em parte o motivo de ter sido a geometria historicamente 0 primeiro ramo do conhecimento a ser apresentado de maneira Lógica Formalizada. Mas fica claro que a Matemática apresenta um padrão lógico que varia ao longo de sua História.

\footnotetext{
211 Ibid., p. 6

212 Cf. Ibid., p. 7

213 Ibid., p. 25

214 lbid., p. 4
} 
Demonstrar tinha um significado no tempo de Pitágoras e outro no tempo de Euclides. Isso vale para a evolução da Matemática como um todo, ou em grandes áreas como a representada pela Geometria, mas também se aplica ao processo geral de criação matemática, como se dá por exemplo atualmente num trabalho de pesquisa científica.

Em sua obra $A$ Criação Científica ${ }^{215}$, Abraham Antoine Moles analisa o processo geral de construção do conhecimento científico, e também identifica a ampla significação dos termos lógica e demonstração. Moles parte do princípio de que, de modo geral, demonstrar um fato é construir um sentimento de evidência deste em um indivíduo receptor, comunicando-lhe uma mensagem cujos elementos formam uma série de evidências elementares ${ }^{216}$. Essa definição de caráter amplo apoia-se em duas noções fundamentais: sentimento de evidência e evidência elementar. De acordo com a interpretação dessas duas noções, surgem os diversos significados do termo demonstração. Para caracterizar uma demonstração é necessário inicialmente distinguir a natureza das evidências elementares que devidamente encadeadas geram a demonstração. $O$ que define que uma seqüência de sentenças ou proposições seja ou não uma demonstração é o sistema lógico dentro do qual se está considerando a demonstração. Portanto, podemos encontrar demonstrações autênticas em diversas situações do cotidiano, cada uma delas com seu nível ou sistema lógico peculiar.

Analisando a questão da demonstração, Machado217, faz referência ao sentido lato que Moles sugere para o termo, acrescentando:

Concebida assim, a noção de demonstração inclui tanto a de proposições da Matemática quanto a de proposições científicas em geral, ou mesmo proposições de qualquer natureza. Para a construção de uma demonstração, deve-se selecionar e explicitar as evidências elementares que constituirão o ponto de partida necessário e que dependerão, fundamentalmente, do canal de comunicação que vier a ser estabelecido entre o emissor e o receptor da mensagem ${ }^{218}$.

Nesse sentido, pode-se dizer, por exemplo, que a demonstração da qualidade de um produto feita por um vendedor diante de um grupo de possíveis compradores utiliza uma determinada estruturação lógica. Quando um promotor expõe diante dos jurados os elementos incriminadores do réu, faz uso de modos lógicos distintos. Diferente nível lógico é aquele empregado nos diálogos entre alunos: ao explicar para seu colega de classe a matéria que ele perdeu na aula em que faltou, geralmente um aluno emprega uma abordagem lógica que não é a mesma que o professor utilizou na sua explanação. Quando um cientista afirma ter realizado uma descoberta de vulto, precisa esgrimar argumentos aceitáveis pela comunidade científica, os quais podem ser muito diferentes dos que ele utiliza para explicar o mesmo assunto a um amigo, se ele for um leigo na matéria. Do mesmo modo uma mãe precisa argumentar distintamente com filhos de diferentes idades, ainda que as idéias que queira transmitir a cada um deles sejam semelhantes. A palavra lógica tem um significado histórico determinado, embora se possa utilizá-la, num sentido amplo, para significar a forma de se estruturar uma argumentação, a qual assume padrões variados.

Para cada combinação de emissor e receptor de uma mensagem, há portanto, uma argumentação lógica e uma forma de demonstração distintas. A adequada assimilação do conteúdo da mensagem a ser comunicada depende do uso da abordagem lógica compatível. Isso possui uma importância evidente para o ensino, e levou Moles a sugerir o esquema simbólico da Matriz de Comunicação Pedagógica, distribuindo por linhas e colunas os diferentes tipos de pares de interlocutores. Cada posição linha/coluna da matriz supõe o recurso a um sistema lógico distinto conforme a natureza das evidências elementares adequadas para que a comunicação seja eficaz 219 .

\begin{tabular}{|c|c|c|c|c|c|}
\hline & aluno & professor & pesquisador & técnico & \\
\hline aluno & & & & & \\
\hline
\end{tabular}

\footnotetext{
215 MOLES, Abrahan Antoine. A Criação Científica. Trad. de G. K. Guinsburg. São Paulo, Perspectiva/EDUSP, 1971.

216 Cf. Ibid., p. 37

217 MACHADO, Nílson José. Matemática e Língua Materna: Análise de uma Impregnação Mútua. São Paulo, Cortez, 1990. 169 p.

218 Ibid., p. 37

219 Cf. MOLES, op. cit., p. 37
} 


\begin{tabular}{|c|l|l|l|l|l|}
\hline professor & & & & & \\
\hline pesquisador & & & & & \\
\hline técnico & & & & & \\
\hline & & & & & \\
\hline
\end{tabular}

Para os fins a que nos propomos, é interessante constatar ainda a existência de níveis lógicos distintos no livro didático e no caderno do aluno. Enquanto no livro didático a Matemática pode ser apresentada segundo sua estrutura lógica interna, própria de uma Ciência sistematizada, no caderno ela se encontra organizada de acordo com a lógica de sua construção: erros, correções, tentativas de resolução parcial de problemas, esboços de dúvidas, explicações orais anotadas de modo sucinto, exemplos, resumo de teoria aos pedaços, etc. Sem dúvida muitos estudos interessantes poderiam ser feitos sobre o melhor modo de aproveitamento do caderno como material didático. Para nós, nesse momento, é suficiente constatar a existência desses dois níveis lógicos, para que os tenhamos como base na distinção entre a Matemática construída ao longo de sua História e a Matemática sistematizada formalmente.

Ainda no que se refere a essas duas vertentes da lógica mencionadas acima, voltemos à distinção entre uma demonstração pedagógica e uma demonstração formal. A demonstração em Matemática freqüentemente faz uso da Lógica Formal, mas existem outros tipos de demonstração que utilizam outros níveis lógicos e outros tipos de evidências elementares. Embora haja quem prefira dar nomes que não o de demonstração para a construção de certezas baseadas em outros sistemas lógicos, o fato é que todos esses processos podem ser caracterizados como demonstrações. Alguns preferem dizer que fora da Lógica Formal estrita pode-se apenas mostrar um fato. Mas a diferença entre mostrar e demonstrar não é assim tão precisa. Pode-se demonstrar algo informalmente, ou mostrar de modo formal um resultado.

Sem dúvida, a lógica própria da Matemática enquanto ramo específico do conhecimento científico, enquanto Ciência sistematizada, é a Lógica Formal. Para que uma proposição seja matematicamente aceitável, necessita de uma prova formal, cuja validade seja referendada pela comunidade científica, segundo os critérios de rigor estabelecidos. Do ponto de vista pedagógico, poderíamos encaixar esse nível de Lógica Formal na Matriz de Comunicação Pedagógica de Moles na posição indicando o diálogo entre pesquisadores em Matemática pura, sendo a linguagem das publicações científicas e das teses acadêmicas 220 . Uma vez, porém, que os interlocutores do diálogo educativo nem sempre são pesquisadores em Matemática, esse nível lógico não é o mais adequado para o ensino em geral. No nível elementar é muito mais claro ainda que o caminho lógico do aprendizado não é o mesmo da Matemática pronta, sistematizada221. Como afirmou Kline, embora não haja dúvida de que

a prova dedutiva é a marca distintiva da Matemática (...), a prova como critério para a aceitação de um resultado pelos matemáticos e a prova considerada do ponto de vista da pedagogia são questões inteiramente diferentes $^{222}$,

pois envolvem níveis lógicos distintos. Essa separação entre demonstração pedagógica e demonstração formal matemática é identificada por Bochenski como fazendo parte da própria essência da Lógica Matemática:
A lógica matemática exclui de seu domínio todas as considerações de ordem psicológica e epistemológica; ocupa-se unicamente da análise de correção das leis lógicas puramente formais, tais como o princípio da contradição, o silogismo hipotético, etc.(...) Os lógicos

\footnotetext{
220 No mesmo contexto se inserem os diálogos entre pesquisadores e professores de nível superior, como se registra nas palavras do Prof. Dr. Reinaldo Salvitti, do Instituto de Matemática e Estatística da Universidade de São Paulo, em entrevista concedida em 5 de outubro de 1989: Uma demonstração matemática é clara, e não se limita a um convencimento do outro. Demonstrar não é convencer. Uma demonstração não formal pode convencer, sem ser no entanto uma demonstração. $O$ fato mostrado pode até estar errado. Demonstração como mero convencimento é passível de engano. Segundo também afirma a Profa. Dra. Maria Ignez de Souza Vieira Diniz, do mesmo Instituto, em entrevista de 2 de agosto de 1990: Fora do sistema formal, o que se faz é apenas mostrar, convencer, e portanto não pode haver fora dele nenhuma demonstração propriamente dita.

221 Mas isso não vale somente para a Matemática elementar: Mesmo num curso superior - comenta a Profa. Maria Ignez -, consideram-se teoremas não provados como se fossem postulados, pois para demonstrar muitos deles seriam necessários conhecimentos que vão além dos cursos de Graduação.

222 KLINE, Morris. O Fracasso da Matemática Moderna. São Paulo, Ibrasa, 1976. p. 189
} 
matemáticos empregam o formalismo. Por formalismo designa-se o seguinte método: começa-se por escolher certos símbolos que possuem em si e por si uma significação determinada; em seguida, prescinde-se completamente dessa significação e consideram-se os teoremas exclusivamente segundo a forma externa, gráfica, dos símbolos, e não segundo sua significação. Toda a dedução se processa, portanto, de modo puramente "formalizado", ou, por outras palavras, é uma lei rigorosa da lógica matemática que, no interior da demonstração, se faça apelo tão só à forma dos símbolos e às regras dedutivas formais concernentes a esta forma ${ }^{223}$.

O distanciamento dos aspectos psicológicos ou epistemológicos que toma lugar no decorrer de um processo de demonstração formal faz com que não deva ser tomado como um caminho adequado ao ensino elementar, no mesmo sentido de caminho apontado por Bochenski para o termo metodologia: pois uma abordagem que se pretenda pedagógica deve levar em conta o modo de pensar natural do aluno. Ainda que seja possível - e essa é já uma outra discussão - colocar entre os objetivos do ensino de Matemática justamente a aquisição desse padrão lógico de raciocínio que é peculiar da Lógica Formal, não se pode deixar de considerar que até mesmo para ensinar Lógica Formal é necessária uma linguagem, uma metodologia ou uma lógica natural. A menos que se pressuponha que os alunos já pensem anteriormente de modo lógico formal, o que aliás também tornaria desnecessário o ensino de lógica.

Kneale e Kneale, ao final do seu tratado O Desenvolvimento da Lógica, comentam essa distinção entre o pensamento e os modelos lógico-formais, referindo-se, no caso, aos trabalhos de George Boole (1815-64), que exprimia relações lógicas por meio de fórmulas algébricas:

Embora Boole tenha chamado sua obra mais ambiciosa em lógica The Laws of Thought e tivesse algumas vezes escrito como se se imaginasse a si próprio a investigar a constituição do intelecto humano, é óbvio que a álgebra de Boole não tem nada que ver com os processos de pensamento. Em cada uma das interpretações a que chamamos lógicas ela trata das relações entre entidades que são inteiramente não-mentais 224 .

Parece assim ficar claro que se quisermos obter uma caminho lógico, ou, nesse sentido, uma metodologia adequada aos processos de pensamento dos alunos de Matemática elementar, precisamos recorrer a outros níveis lógicos, que não o característico da Lógica Formal. É preciso salientar nesse ponto da discussão que não pretendemos contrapor a ordem lógica à ordem psicológica, o que esperamos já ter ficado justificado suficientemente pelas discussões anteriores. A contraposição que acabamos de mostrar acima refere-se unicamente à ordem Lógica Formal. Entendemos que o processo de pensamento dos alunos percorre, de modo habitual, as vias da lógica natural, que é também uma lógica, e cuja fonte primordial é a própria linguagem comum.

Esse caminho pedagógico parece advir, segundo as análises que acabamos de realizar, da consideração da Matemática enquanto Ciência em fase de construção científica, e não da Matemática pronta e sistematizada de acordo com a Lógica Formal. A visão da Matemática em construção é precisamente a que obtemos pelo estudo da História da Matemática, a qual surge assim como a grande fonte para a apreensão da organização lógica mais adequada ao ensino da Matemática, principalmente no nível elementar, onde os padrões lógico-formais estão ainda mais distantes dos alunos. A forte relação da lógica com o ensino constitui, portanto, um componente decisivo para a avaliação do uso da História da Matemática como recurso pedagógico, revelando com muita profundidade seu valor didático.

Mas como fazer uso da História da Matemática nesse nível? Alguns autores pretendem que a simples reprodução das etapas lógicas da construção histórica do conhecimento matemático seja suficiente para se obter um ensino logicamente adequado ao aluno. Aaboe 225 , um matemático interessado pelo valor didático da História da Matemática,

\footnotetext{
223 BOCHENSKI, Innocentius Marie. A Filosofia Contemporãnea Ocidental. Trad. de Antonio Pinto de Carvalho. 3a ed. São Paulo, EPU/EDUSP, 1975. 300 p., p. 232

224 KNEALE, op. cit., p. 747

225 AABOE, Asger. Episódios da História Antiga da Matemática. Trad. de João Pitombeira de Carvalho. Rio de Janeiro, Sociedade Brasileira de Matemática, 1984. 170 p.
} 
aconselha evitar um generalização excessiva desse paralelismo entre evolução científica e ensino de Ciências, mas sugere que há algo de valioso nessa interrelação:

Um principiante deve começar pelo início, e o começo é freqüentemente composto de material velho. Posso ilustrar isso com uma citação biológica que, devido a sua forma curiosa, gravei na memória. Diz que a ontogenia recapitula a filogenia, e isso significa que, no desenvolvimento de um indivíduo, vemos, em passagem rápida, o desenvolvimento de toda sua espécie. Tomada literalmente, esta afirmação pode conduzir, e tem conduzido, a todo tipo de absurdos, mas apropriadamente restrita contém algo de verdadeiro. Da mesma maneira modificada, ela se aplica à espécie dos matemáticos. 0 desenvolvimento embriônico de um matemático, isto é, a educação que o conduz dos princípios até à frente de pesquisa de sua época, segue com efeito, grosseiramente, o desenvolvimento da própria matemática ${ }^{226}$.

A referência à hipótese do paralelismo onto-filogenético é lugar comum entre os pesquisadores e autores de livros de História da Matemática, mas essa hipótese situa-se no centro de uma controvérsia de não pequenas proporções, e não nos deteremos aqui nesse ponto. Mesmo Piaget e Garcia, por exemplo, ao escreverem sobre a psicogênese do conhecimento científico, são prudentes nesse ponto e não se arriscam a ser categóricos:

No devir histórico, os fatos não são, em geral, claros, nem os efeitos tão facilmente isoláveis. 0 progresso científico, a busca de determinadas formas de explicação, a aceitação ou a rejeição de conceitos e de teorias de um certo tipo respondem, no mais das vezes, a um jogo de interações complexas, em que os fatores sociais e as exigências internas do próprio sistema cognitivo são complementares e reforçam-se ou opõem-se e atenuam-se 227 .

Esse complexa rede de interações impõe sérias dificuldades a quem pretende estudar a História da Matemática visando descobrir um princípio geral da evolução do conhecimento matemático que possibilite a interpretação e conseqüente utilização didática da História da Matemática. Como adverte Boyer, nas páginas finais da sua História da Matemática:

Pelo conhecimento do passado pode-se prever num sentido muito geral o que o futuro pode conter. Mas se há um elemento de verdade no aforismo "a história se repete", a História da Matemática mostrou contudo que as "repetições" são tão variadas e imprevistas que impedem qualquer previsão significativa das coisas que estão para vir 228 .

Essa ausência de um princípio claro que determine a evolução histórica da Matemática, essa verdadeira indeterminação histórica, constatada por Boyer no final do seu longo estudo, pode aparentar ser um aspecto negativo do recurso à História da Matemática como fonte da lógica. Parece retratar a História da Matemática como uma sucessão de fatos sem relação clara entre si, tornando difícil a apreensão da lógica da construção do conhecimento matemático simplesmente recorrendo à História da Matemática. No máximo, chega-se a uma idéia vaga de que existe uma analogia ampla entre o ensino e a História da Matemática.

Diante de uma visão em bloco tal como nos oferece um livro do tipo cronológico, fica realmente difícil discernir uma lógica adequada ao ensino de um tópico específico, embora essa visão de conjunto seja também um componente importante do valor didático da História da Matemática, conforme será examinado mais adiante. Quanto à lógica de cada tópico, é mais fácil reconhecê-la nos livros por assunto. Esses livros possuem um valor didático muito distinto dos demais, porque o acesso ao seu conteúdo se dá através dos tópicos de Matemática. A sua própria organização interna permite sua utilização seja qual for a seqüência curricular adotada. Não exigem que o leitor conheça História e Matemática a fundo para poder fazer uso deles, pois apresenta a evolução histórica de cada tópico em

\footnotetext{
226 Cf. lbid., p. 5

227 PIAGET, Jean \& GARCIA, Rolando. Psicogênese e História das Ciências. Lisboa, Publicaç/Ees Dom Quixote, 1987,247 p., p. 236

228 BOYER, Carl Benjamin. História da Matemática. Trad. de Elza F. Gomide. São Paulo, Edgard Blücher, 1974, 488 p., p. 459
} 
particular. E é aí que obtemos a lógica da Matemática em construção, ou melhor, da construção do assunto matemático específico que se quer ensinar, evitando generalizações excessivas.

É importante dosar a intensidade do recurso à História como instrumento de ensino de tal ou qual tópico. Utilizando um livro de História da Matemática por assunto, o professor pode aprofundar o quanto queira na História, e fazer uso de toda essa informação junto aos alunos, que ficam sabendo quando, e em que circunstâncias desenvolveu-se tal assunto. Essa digressão histórica pode ter uma certa duração. Mas pode também - e esse é, sem dúvida, o grande potencial didático desse tipo de livro - simplesmente captar na gênese histórica de um tópico específico o modo, a metodologia, a lógica que caracterizaram seu surgimento. A partir daí, procura-se reproduzir na sala de aula passos análogos aos da seqüência criadora do conhecimento que se quer transmitir. Não é necessário, nesse nível de utilização, contar a História propriamente dita de um assunto. Deixando de lado dados supérfluos, pode ser suficiente ater-se somente à seqüência lógica que levou à construção daquele conhecimento matemático pelos homens de outrora, depurando-a de pormenores desnecessários ou de desvios irrelevantes para os fins almejados.

Para isso, o conhecimento histórico requerido por parte do professor é muito mais profundo. Não basta saber alguns dados biográficos que possam ilustrar as aulas, nem saber localizar no espaço e no tempo o conteúdo do currículo. É necessário ir além, adentrando os processos de criação da Matemática, tal como nos apresenta a sua História, e obtendo as chaves para abrir aos alunos as portas de acesso ao conhecimento matemático. Essa imagem das chaves não é, entretanto, inteiramente apropriada, pois dá margem a que se pense que o acesso à Matemática se dá por meio de portas com fechadura de segredo único, e não é isso que queremos dizer. Na verdade, esse mergulho na História da criação matemática justamente leva a descoberta de uma infinidade de modos de se chegar a um resultado, desde que se respeite a lógica própria da construção do conhecimento, a qual permite uma ampla variedade de abordagens.

A vida de Gauss, por exemplo, pode ser interessante de ser apresentada aos alunos. Mas basta um pequeno trecho, um pequeno fato narrado com simplicidade, para que captemos a lógica para ensinar um assunto como a fórmula da soma da Progressão Aritmética. Conforme já mostramos ao falar sobre o livro de Bell ${ }^{229}$, o que interessa é que Gauss tenha conseguido, aos dez anos (e portanto antes de ter aprendido qualquer coisa sobre o rigor formal matemático), somar uma série de 100 números simplesmente observando que a soma do primeiro com o último era igual à soma do segundo com o penúltimo e assim por diante. Se o professor quiser trabalhar com os alunos sobre a vida inteira de Gauss ou se quiser colocá-los a par do que se passava no mundo quando Gauss tinha dez anos, isso é outra questão. Pouco importa também se os números somados forem os de 1 a 100, ou, como relata Bell, de 81495 até 100899, com passo 198. Para que se obtenha a lógica da construção desse conceito, que é o fim a que nos propomos, tampouco faria grande diferença se o professor trocasse o nome de Gauss pelo de Euler ou Newton, ou ainda se dissesse que foi um primo seu o autor da proeza. Ao dizer isso não estamos querendo desprezar a verdade histórica, mas apenas ressaltar que tipo de informação é fundamental de se buscar na História da Matemática para obter a lógica, e que tipo de informação é apenas complementar. 


\subsection{História da Matemática e Significado}

Não tome da matemática e da metafísica mais do que o estômago pode suportar; o que não dá prazer não dá proveito. Em resumo, senhor, estude apenas o que Ihe agradar.
Shakespeare 230
Que diferença essencial existe entre ensinar um animal humano a usar um algoritmo para encontrar a raiz quadrada de um número e ensinar uma pomba a apertar certas combinações de botões coloridos para obter alimento?

Wilder231

Outro componente importante do valor didático da História da Matemática está relacionado à representação da Matemática em linguagem simbólica. Da interpretação dessa linguagem simbólica pode depender não só o aprendizado em si, como também a motivação para ele. Mas o ensino elementar em geral tende a enfatizar a técnica de fazer cálculos, deixando para segundo plano o cuidado na apreensão do significado dos mesmos por parte dos alunos. Acaba-se, assim, operando com símbolos matemáticos com pouco ou nenhum conhecimento do significado das operações realizadas. E muitas vezes a Matemática torna-se objeto de aversão por parte dos alunos do nível elementar, justamente pela dificuldade de compreensão de sua linguagem.

Uma autêntica crise psicológica de bloqueio e repúdio à aprendizagem da Matemática foi identificada por Segal, no seu estudo sobre a chamada Mathematical Anxiety:

Claramente o analfabetismo matemático e a ansiedade matemática alimentam-se um ao outro. 0 que não se sabe causa ansiedade, a qual inibe o desempenho, o que causa maior ansiedade, e assim por diante(...). "Uma matéria detestável"; uma vez que o aluno começa a temer a Matemática e a evitá-la, inicia-se o ciclo de ansiedade crescente e absoluto analfabetismo matemático ${ }^{232}$.

O que causa o início desse ciclo de aversão à Matemática não é objeto de estudo de Segal. Seu trabalho consistiu em detectar a presença desse ciclo destruidor entre alunos de diversos níveis. Mas ao apontar para uma possível causa, diz que alunos com aversão séria à Matemática também têm deficiência na utilização dos componentes lógicoverbais do raciocínio:

\section{parecem ter extraordinária dificuldade com problemas verbais ${ }^{233}$. \\ Certamente alunos que têm problemas em Matemática Isso já constitui um indício do fato de que o ensino da Matemática está} profundamente relacionado com a compreensão da linguagem. A própria motivação para o aprendizado pode ficar comprometida, surgindo no aluno uma inquietação natural com relação à razão de ser daquele estudo, tão mais árido quanto mais obscuro parece ser seu significado. Quando um aluno pergunta por que deve estudar um tópico determinado, 0 professor às vezes sugere que ele espere até um futuro mais ou menos distante, no qual certamente estará maduro o suficiente para entender o porquê das coisas. De fato, um posterior estudo prolongado e aprofundado de Matemática em nível superior pode esclarecer muitas dúvidas que o aluno pudesse ter quando estudava Matemática elementar, se é que ele ainda lembra quais eram. Mas, considerando que poucos alunos do nível básico irão prosseguir os estudos em Matemática especificamente, esse argumento fica no mínimo inaplicável a muitos alunos. A fragilidade desse tipo de argumentação já era identificada por Kline na década de 70:

\footnotetext{
230 SHAKESPEARE. A Megera Domada. Ato I (palavras de Trânio). Trad. de Millôr Fernandes. Porto Alegre, L \& PM Editores, 1979, 164 p., p. 26

231 WILDER, Raymond Louis. Evolution of Mathematical Concepts. New York, John Wiley, 1973. 216 p., p. 5

232 SEGAL, S. L. Mathematical Anxiety: Real or Imaginary? In: Ciência e Cultura. 36(1), Janeiro de 1984. pp. 9-15, p. 10

233 Ibid., p. 14
} 
Tem-se que apresentar a motivação juntamente com o tópico a ser ensinado. Não adianta assegurar aos alunos que algum dia apreciarão o valor da Matemática que se lhes pede que aprendam ${ }^{234}$.

Esse interesse imediato que pode ligar o aluno ao estudo da Matemática pode ser de várias formas, mas sem dúvida o significado da matéria é ponto central, pois sem acesso a ele não pode haver interesse nem motivação autênticos. É claro que a motivação para o aprendizado é questão complexa, e nem cabe ao professor lidar sozinho com ela. A ele cabe, isso sim, cuidar que o significado daquilo que vai ensinar esteja transparente no seu processo pedagógico. Pois pode-se afirmar que um aluno entende o que um símbolo matemático representa não só quando é capaz de fazer dele um uso apropriado dentro da linguagem matemática, mas também quando passa a ver o símbolo não como algo abstruso, mas sim importante e útil, algo que vale a pena ser conhecido. Um ensino significativo é um ensino motivador, e a falta de motivação para o aprendizado decorre muitas vezes da distância com relação ao significado daquilo que deve ser aprendido.

Se vemos que um ensino rico em significado é motivante e pode tornar o aprendizado da Matemática atraente e agradável, ou, no mínimo, interessante, é bom tentar compreender o que é significado. As metas e limites deste trabalho não nos permitem iniciar aqui uma discussão filosófica acerca do "significado do significado". Existem muitas interpretações da noção de significado, elaboradas por vários filósofos, de Platão a Wittgenstein. Sem entrar em questões metafísicas, que, como já dissemos, estariam fora do âmbito desse trabalho, pode-se pelo menos afirmar ser possível construir, junto com o aluno, o significado de uma noção que se quer ensinar. Observando a própria evolução da linguagem científica, percebem-se inúmeras modificações e transferências de significados. Acompanhando a História das Ciências, vemos que ocorrem alterações não somente nos significantes ou símbolos empregados, mas também nos significados.

Exemplo simples nos fornece a História da Noção de Número. A par dos diferentes sistemas de numeração já empregados pela humanidade, constata-se também uma enorme variação do significado de Número ao longo da História. Basta considerar a crise da Escola Pitagórica causada pela descoberta dos Incomensuráveis por volta do século $\mathrm{V}$ a.C235. A perplexidade dos matemáticos pitagóricos não decorre da dificuldade de representação simbólica dos Irracionais, mas da apreensão do seu significado. A incorporação da noção de Grandeza Incomensurável não representou uma alteração nos símbolos numéricos, mas no significado de Número. Compreender essa evolução dos significados ao longo da História é fundamental para a elaboração de um ensino com significado, pois permite que se construam novamente os significados junto com os alunos.

Mesmo sem a pretensão de entrar em discussões muito específicas sobre o estudo dos símbolos, necessitamos abordar alguns temas básicos sobre linguagem simbólica para prosseguir a análise do valor didático da História da Matemática. Entendemos que para um trabalho pedagógico adequado com a simbologia da linguagem matemática seria necessária uma visão mais profunda da Matemática enquanto Ciência. Como toda Ciência, a Matemática possui uma linguagem simbólica que a expressa. Bochenski236 fornece três razões para justificar a necessidade dos símbolos ou signos para a linguagem científica em geral, que podem-se aplicar também à Matemática:

\begin{tabular}{|l|l|}
\hline & $\begin{array}{l}\text { Em primeiro lugar, a Ciência é obra coletiva, e portanto há a } \\
\text { necessidade de comunicação do saber, que se dá através dos } \\
\text { signos, símbolos, palavras. }\end{array}$ \\
\hline \multirow{2}{*}{3} & $\begin{array}{l}\text { Esses símbolos, sendo algo material, facilitam o desenrolar do } \\
\text { entendimento humano, que está mais capacitado para a } \\
\text { apreensão de objetos materiais. }\end{array}$ \\
\hline $\begin{array}{l}\text { Ao procurar expressar suas idéias por meio de símbolos, ocorre } \\
\text { um processo de elaboração e delineamento das próprias idéias, o } \\
\text { que é muito útil para o progresso científico. }\end{array}$ \\
\hline
\end{tabular}

\footnotetext{
234 KLINE, Morris. O Fracasso da Matemática Moderna. São Paulo, IBRASA, 1976. p. 183

235 Ver também BROLEZZI, Antonio Carlos, et al. História da Matemática: um Recurso Pedagógico. Capítulo 2 da Proposta Curricular de Matemática para o CEFAM e Habilitação Específica para o Magistério. Diversos Autores. São Paulo, Secretaria de Educação, 1990. 257 p., pp. 27-36

236 Cf. BOCHENSKI, Innocentius Marie. Los Metodos Actuales del Pensamiento. Traducción de Raimundo Drudis Baldrich. 2a ed. Madrid, Rialp, 1958. 278 p., p. 72-3
} 
Essas razões parecem suficientes para justificar o trabalho com símbolos no ensino da Matemática. A linguagem simbólica matemática não pode ser encarada como um mal necessário, pois faz parte das características próprias dessa Ciência. Trata-se de lidar com essa linguagem de modo a que o aluno a compreenda, para que não se torne uma barreira ao aprendizado, e antes sirva para os fins acima descritos.

Tanto no que se refere à Teoria Científica quanto - como no nosso caso com relação ao ensino, a utilização de símbolos constitui-se num grande campo de estudo. 0 importante papel dos símbolos está associado ao desenvolvimento da Semiótica, termo cunhado em 1938 por Charles Morris ${ }^{237}$ para designar o estudo das questões específicas levantadas pelo uso de símbolos. A idéia central da Semiótica consiste em realizar uma nítida distinção entre o símbolo e o que ele significa ${ }^{238}$. Nessa distinção, a Semiótica clássica faz uso de três ordens de relação: Sintaxe, Semântica e Pragmática:

A sintaxe considera o símbolo independente do seu significado, reconhecendo apenas as relações entre os símbolos dentro da linguagem considerada. $O$ estudo dos símbolos relacionando-os com seus significados é objeto da semântica. Englobando ambas as ordens de relação situa-se a pragmática, que aborda ainda o modo como um símbolo é utilizado pelo indivíduo interpretante ou usuário da linguagem. Essas categorias semióticas clássicas aplicam-se a símbolos de qualquer linguagem. No caso de uma linguagem formalizada, como a que emprega a Matemática considerada enquanto Ciência sistematizada, a relação sintática ou sintaxe dos símbolos é preponderante sobre a relação semântica. Isto é, em palavras de Machado,

os signos são definidos ou caracterizados a partir das relações que estabelecem com os outros, no interior do formalismo; eles nada significam, senão o que expressam através de tais relações ${ }^{239}$.

De fato, conforme as características do formalismo expressas no item

anterior ${ }^{240}$, dentro do processo de formalização existe um necessário distanciamento do significado, que é conseqüência de se fazer uma abstração do significado dos símbolos empregados para somente considerá-los como sinais gráficos ${ }^{241}$. É dessa separação entre Semântica e Sintaxe que decorre a aparência abstrusa da linguagem simbólica da Matemática.

Obviamente, não estamos afirmando que os símbolos da linguagem da Matemática formalizada não possuem significado. Mas esse significado, que pode ser claro aos olhos dos pesquisadores, é freqüentemente obscuro para quem está ainda procurando aprender Matemática elementar. Para um aluno de Matemática elementar, essa simbolização distante do significado pode aparentar simplesmente a não existência de significado algum. As relações sintáticas somente podem ser apreendidas pelo aluno aos poucos, na medida em que ele vá compreendendo a estrutura formal da Matemática sistematizada, conforme nos referimos no item anterior ao falar da questão da lógica ${ }^{242}$. É a essa realidade que faz referência por exemplo Hoffer, ao falar sobre o ensino de Geometria:

Muitos cursos de Geometria para o secundário põem ênfase no desenvolvimento por parte dos alunos da habilidade de escrever provas formais.(...) Por começar provas formais muito cedo num curso de Geometria, podemos não levar em conta aqueles alunos que ainda não alcançaram um nível suficientemente alto de desenvolvimento mental que os capacite funcionar adequadamente no nível formal ${ }^{243}$.

Portanto, para a obtenção de um ensino significativo, é necessário levar em consideração o nível de desenvolvimento mental do aluno, o qual não se encontra apto para compreender o nível sintático da Matemática que ainda está apenas começando a estudar. Do ponto de vista da Matemática formalizada, os símbolos matemáticos estão

\footnotetext{
237 Cf. Ibid., p. 71

238 Cf. BOCHENSKI, Innocentius Marie. A Filosofia Contemporãnea Ocidental. Trad. de Antonio Pinto de Carvalho. 3a ed. São Paulo, EPU/EDUSP, 1975. 300 p., p. 237

239 MACHADO, Nílson José. Matemática e Língua Materna: Análise de uma Impregnação Mútua. São Paulo, Cortez, 1990. 169 p., p.112

240 Cf. parte 3, capítulo 1, nota 22

241 Cf. BOCHENSKI, Innocentius Marie. Los Metodos Actuales del Pensamiento. Traducción de Raimundo Drudis Baldrich. 2a ed. Madrid, Rialp, 1958. 278 p., p. 78

242 Cf. parte 3, capítulo 1, nota 21

243 HOFFER, Alan. Geometry is More than Proof. In: Mathematics Teacher. V. 74(1) January 1981. pp. 11-18, p. 14
} 
situados num nível sintático distante da semântica e, por conseqüência, da pragmática, já que o significado de um signo está associado diretamente ao seu uso ${ }^{244}$.

A ênfase às vezes dada ao desenvolvimento das habilidades de realizar cálculos e operações, em detrimento do tratamento adequado do significado dos símbolos e algoritmos utilizados, pode ser uma das causas da aversão à Matemática registrada por Segal. Como também constatou Machado, há uma estreita relação entre o ensino de Matemática e o significado:

Muito mais do que a aprendizagem de técnicas para operar com símbolos, a Matemática relaciona-se de modo visceral com o desenvolvimento da capacidade de interpretar, analisar, sintetizar, significar, conceber, transcender o imediatamente sensível, extrapolar, projetar $^{245}$.

Todas essas habilidades que podem ser desenvolvidas pelo ensino de Matemática estão na dependência de um tratamento profundo do significado. Pode-se adquirir maior ou menor habilidade técnica de cálculo e utilização de algoritmos, ainda que não se tenha uma noção clara do que se está fazendo. Esse enfoque muito voltado para a prática constitui-se, como comenta Lauand ${ }^{246}$, numa visão apenas parcial das funções do ensino da Matemática:

Ensinar Matemática não é ensinar expedientes práticos para a resolução de problemas de imediata utilidade. Mesmo que se aprendam, passado algum tempo, esquecem-se esses expedientes ou mudam as circunstâncias 247 .

E por não haver captado o real significado do que estava fazendo, o aluno não é capaz de utilizar essas técnicas em outros contextos ou outras situações.

Aqui entra novamente em jogo o recurso à História da Matemática. Observando as origens de um assunto, captamos sua notação simbólica ainda com significado, antes que passem pelo processo de formalização que faz por distanciá-la da relação semântica inicial. A ligação entre a Matemática e a linguagem comum, fonte da lógica natural, aparece então como a ligação entre a Matemática e a realidade, a qual, como diz Lauand ${ }^{248}$, está de algum modo presente na gênese e no desenvolvimento de todo pensamento matemático, e se nos afastamos dessa relação, a Matemática tende a transformar-se num mero jogo sintático. É pelo recurso à História da Matemática que impedimos que a Matemática se torne, aos olhos dos alunos, uma sintaxe estéril.

Quando propomos apontar para a realidade, via História, como meio de alcançar o significado no ensino da Matemática elementar, é importante deixar claro que não estamos discutindo a relação entre a Matemática e a Realidade, questão ampla que está fora do âmbito desse trabalho 249 . Para nós agora basta admitirmos o significado como algo que se constrói, que varia na medida em que evolui historicamente o conhecimento matemático a que ele se refere.

Somente considerando a Matemática como algo estático e não construída ao longo do tempo, se poderia chegar à conclusão de que não se pode conhecer seu significado fora do âmbito da própria lógica interna da Matemática. Esta não é acessível, obviamente, àqueles que não conhecem ainda a Matemática como uma Ciência formalizada, como por exemplo os alunos de Matemática elementar. Para aprender Matemática, e depois também fazer-se senhor de sua lógica, é preciso passar por um estágio intermediário em que a lógica utilizada é a do senso comum, que utilizamos no nosso modo habitual de pensar, e que é utilizada por exemplo para contar histórias. O significado faz-se então presente no ensino de Matemática elementar, quando se recorre ao uso da História da Matemática. Conforme constataram Piaget e Garcia,

tornou-se claro para todos que a ciência está em perpétuo devir e que não se pode considerar nenhum setor, por mais limitado que seja, como

244 Cf. MACHADO, Nílson José. Matemática e Língua Materna: Análise de uma Impregnação Mútua. São Paulo, Cortez, 1990. 169 p., p. 111

245 Ibid., p. 96

246 LAUAND, Luiz Jean. O Ensino de Matemática e sua Dimensão Filosófica e Social. In: Educação \& Matemática. 1978(2), Set-Dez, pp. 28-39

247 lbid., p. 30

248 Ibid., p. 33

249 A respeito desse tema, ver MACHADO, Nílson José. Matemática e Realidade. São Paulo, Cortez, 1987, 103 p. 
definitivamente estabelecido sobre suas bases e protegido de qualquer modificação posterior(...). Nestas condições de devir geral está implícito que um conhecimento não poderia estar dissociado do seu contexto histórico, e que, por conseqüência, a história de uma noção fornece alguma indicação sobre o seu significado epistêmico ${ }^{250}$.

O significado de uma noção elementar de Matemática pode ser esclarecido com base numa estrutura interna da Matemática que necessariamente não é acessível ao aluno naquele momento. Mas a história daquela noção, que muitas vezes remonta a épocas em que a Matemática ainda não havia adquirido toda sua estrutura interna, pode revelar seu significado sem exigir maior nível lógico que o de acompanhar uma contextualização histórica, a qual tem sempre ligação com a realidade humana comum.

Essa ligação com a realidade humana comum é que revela a dimensão semântica dos símbolos, juntamente com sua dimensão pragmática, isto é, seus usos diversos. Isso pode ser melhor observado se compararmos o ensino de Matemática com o de outras matérias, como História, por exemplo. Não é só no ensino de Matemática que surgem símbolos e abstrações. Mesmo nos livros didáticos de História, por exemplo, deparamos com inúmeros esquemas, desenhos e representações abstratas para retratar algo histórico, como por exemplo uma tabela comparando a dinastia Tudor com a dinastia Stuart ${ }^{251}$. Mas essas abstrações não provocam a mesma reação que as do ensino da Matemática, como por exemplo uma tabela comparando as propriedades das operações da adição e da multiplicação dentro do conjunto dos números inteiros ${ }^{252}$. Pois os significados dessas representações simbólicas dos livros de História, mesmo que sejam difíceis de captar integralmente pelo aluno, estão sempre ligados diretamente à realidade do vivido, do histórico, e retratam acontecimentos e pessoas de existência, ainda que casualmente fictícia, pelo menos sempre próximos da dimensão humana em que estamos inseridos.

No ensino da linguagem natural, aparentemente se respeita a ordem lógica do aprendizado, e em geral não se procura enfatizar as questões sintáticas antes que os alunos tenham uma suficiente familiaridade com a semântica, conhecendo o significado das palavras que estão usando para formar frases. No ensino da Matemática, ocorre uma separação radical entre a técnica sintática e a interpretação da linguagem simbólica empregada, tendo como conseqüência a perda de contato com o significado por parte dos alunos. Um símbolo depende de outro e ambos estão relacionados entre si por uma lógica mais inacessível que a que rege a construção de cada símbolo. O aluno é continuamente forçado a atravessar o misterioso mundo da Matemática, e talvez até estivesse disposto a aventurar-se em percorrê-lo e descobrir os segredos dessa nova dimensão, se a urgência das avaliações não restringisse seu tempo ao mínimo necessário para caminhar precipitadamente em direção à resposta certa. Ou seja, o aluno acaba utilizando os símbolos sem conhecer seu significado.

Se o uso de simbologia não é exclusividade da linguagem matemática, nela se encontra em grau elevado, sobretudo do ponto de vista dos alunos, os quais estudam Matemática simbólica muito antes de sequer serem capazes de suspeitar da existência da Semiótica. É claro que não estamos aqui questionando o uso em si dos símbolos matemáticos no ensino da Matemática elementar, mas apenas chamando atenção para o fato de que o ensino, desde seus primeiros anos, está coalhado de uma multidão de símbolos, a começar pelos algarismos indo-arábicos, os quais muitas vezes são tratados como se nem chegassem a ser propriamente símbolos, mas verdadeiras entidades reais de existência óbvia.

Com o recurso à História da Matemática logra-se obter um ensino significativo. É o que também afirma Machado:

Este recurso à História - não à História de povos, épocas ou personagens eventualmente interessantes, mas à História do desenvolvimento das idéias, dos conceitos, do modo como 0

\footnotetext{
250 PIAGET, Jean \& GARCIA, Rolando. Psicogênese e História das Ciências. Lisboa, Publicaç/Ees Dom Quixote, 1987, 247 p., p. 22

251 Cf., p. ex., LUCCI, Elian Alabi. História Geral - $1^{0}$ Grau. São Paulo, Savaiva, 1983. Vol. 1, p. 67

252 Cf., p. ex., JAKUBOVIC, José \& LELLIS, Marcelo. Matemática na Medida Certa (6a série). São Paulo, Scipioni, 1990. p. 70
} 
conhecimento foi produzido - é quase sempre suficiente para revelar uma continuidade essencial em relação ao significado dos temas tratados ${ }^{253}$.

Não estamos, portanto, propondo buscar na História da Matemática a motivação que teria levado à criação de uma determinada idéia matemática, no sentido de mostrar ao aluno a função daquela parte da matéria, para que ele estude-a agora pelo mesmo motivo que levou seus inventores a elaborá-la. Pois isso seria, em boa parte do conteúdo do currículo elementar, irreal. A utilidade atual de uma ferramenta matemática pode ser totalmente diferente da necessidade que a gerou. Os logaritmos, por exemplo, surgiram dentro do contexto da expansão marítima, para facilitar os cálculos com grandes números necessários para o planejamento de longas viagens ${ }^{254}$. Obviamente, sua presença agora no currículo elementar não pode ser justificada pelo mesmo motivo, mesmo que se trate de um curso para marinheiros. Os logaritmos têm, hoje em dia, aplicações práticas muito diferentes das que possuíam na época do seu surgimento. O mesmo se deu com muitos tópicos de Matemática, e no futuro pode-se esperar que se descubram novas aplicações para a Matemática, enquanto outras caiam em desuso. Mas seu significado, associado indelevelmente à sua origem histórica, permanece sempre atual, mesmo que as aplicações mudem ou simplesmente desapareçam. Propomos então que se busque na História o real significado dos logaritmos e outros tópicos da Matemática elementar. Basta que sejamos capazes de revelar o fundo humano por trás daquela idéia matemática, para que ela perca seu aspecto abstruso ocasionado pela simbolização distanciada do significado original.

Para transmitir esse significado aos alunos, o professor não precisa necessariamente contar trechos da História da Matemática relacionados a ele. É suficiente que deixe sua programação curricular impregnar-se do significado histórico, planejando a abordagem dos tópicos de modo a construí-los junto com os alunos, de acordo com o caminho histórico da sua construção original. Narrar biografias ou fazer correlações com os principais eventos da História das Civilizações pode ser um recurso interessante, mas o que importa é que o conteúdo seja iluminado pela História. De pouca utilidade, em termos de significado, são os breves adendos de caráter histórico que encontramos em alguns livros didáticos ${ }^{255}$, se nem de leve chegam a afetar o tratamento do conteúdo. Embora seja inteiramente louvável a introdução dessas referências históricas nesses livros, poderia-se sugerir que também o conteúdo fosse tratado de modo significativo, fazendo uso da História da Matemática. Alguns livros, por uma coincidência muito significativa, trazem inclusive esses relatos históricos em páginas de cores diferentes das dedicadas ao conteúdo em si256. Isso serve de indício para mostrar que não pretendem deixar a parte de História influenciar o tratamento da Matemática, e logo após apresentar um desses textos históricos, expõem um conteúdo matemático que parece nada saber de sua construção histórica, estando antes elaborado inteiramente segundo o formalismo próprio da Matemática sistematizada.

Seria preciso buscar na História não somente o relato episódico, mas informações que definam estratégias de abordagem do conteúdo de forma a revelar o significado do que se está pretendendo ensinar. Exemplo disso podemos encontrar na História da Álgebra. Abrindo o segundo volume da História da Matemática de Smith257 à página 378, deparamos com uma discussão sobre o desenvolvimento da Álgebra que logo de início nos fornece dados interessantes:

Nesselmann (G.H.F. Nesselmann, Alg. Griechen, 1842, p. 302) dividiu a História da Álgebra em três períodos: o retórico, no qual as palavras eram escritas por inteiro; o sincopado, no qual abreviaturas eram usadas; e o simbólico, no qual as abreviaturas deram lugar a tais símbolos como os que ocorrem na sentença $\sqrt{x}-x^{2}=x^{2 / 3}$. Não há linhas exatas de demarcação pelas quais se possa estabelecer essas divisões, tendo Diofanto, por exemplo, feito uso de certas características de todas as três ${ }^{258}$.

\footnotetext{
253 MACHADO, Nílson José. Matemática e Língua Materna. Op. cit., p. 73

254 Cf. Ibid., p. $71-2$

255 Cf., p. ex., IEZZI, Gelson, et al. Coleção Fundamentos da Matemática Elementar. São Paulo, Atual, 1977-81. 10 $v$.

256 Cf., p. ex., PIERRO NETTO, Scipione di. Matemática: Conceitos e Histórias. São Paulo, Scipione, 1991. 4 v.

257 SMITH, David Eugene. History of Mathematics. Boston, Ginn and Co., 1923. 2 v. Vol. II

258 Ibid., p. 379
} 
Seguem-se depois cento e cinquenta páginas onde Smith narra a História da Álgebra, com muitos exemplos de problemas, notações, técnicas de resolução de equações e mais a História dos determinantes, logaritmos, probabilidades, etc. O Professor pode selecionar nesse abundante material aquilo que lhe parecer conveniente utilizar. Pode escrever equações em hieróglifos ${ }^{259}$, ou na notação em grego de Diofanto 260 , ou explicar a regra da Falsa Posição para resolver equações ${ }^{261}$. Mas o que é fundamental é que se possa perceber o cerne da evolução da Álgebra, de modo que as aulas possam ser organizadas segundo as etapas fundamentais da simbolização algébrica. Nesse sentido, o conhecimento histórico é imprescindível.

Outro exemplo pode ser extraído do relato de Heródoto sobre o surgimento da Geometria no Egito262. Não é necessário falar da História do Egito, explicando de que forma o conhecimento das trincas pitagóricas esteve presente na construção das pirâmides e nas demarcações de terras inundadas pelas cheias do Nilo. Basta que apreendamos na História da Matemática que o estudo da Geometria surgiu a partir da observação de objetos reais, e não de forma axiomática desde o princípio. O engenho dos arquitetos e estiradores de cordas egípcios se faz notar pelas construções e resultados práticos obtidos, enquanto a habilidade matemática de Tales e Pitágoras se percebe na descoberta e demonstração de proposições, feita de modo imaterial e intelectual, conforme dissemos ao falar da Tradição Greco-latina. A formalização é historicamente posterior ao trabalho com formas visíveis e palpáveis. É essa a lógica que pode dar significado ao ensino de Geometria, evitando os riscos da formalização prematura.

\footnotetext{
259 Cf. Ibid., p. 422

260 Cf. Ibid., p. 423

261 Cf. Ibid., p. 436

262 Cf., p. ex., HEATH, Thomas Litle. A History of Greek Mathematics. New York, Dover, 1981. 2 v., p. 121-2
} 


\title{
3.3 História da Matemática e Visão da Totalidade
}

\author{
Toda era se inclina a pensar em \\ si mesma como sendo de revolução - um período \\ de tremendas modificações.
}

Boyer 263

Um terceiro componente do valor didático da História da matemática decorre da visão de totalidade e de conjunto que proporciona. Quando se estuda Matemática elementar, muitas vezes é difícil ter uma visão ampla acerca da matéria como um todo. Dentro do currículo elementar, os diversos assuntos surgem bastante isolados uns dos outros, de modo que por si mesmos não são capazes de transmitir uma idéia clara do conjunto do que é estudado. Sem pretender aqui discutir a importante questão da definição do que deve conter um currículo elementar de Matemática, cabe-nos, no entanto, sugerir que se dê aos vários tópicos um tratamento que permita aos alunos uma compreensão mais global acerca do que estão fazendo.

Obviamente, é necessária uma divisão do conteúdo, visando a adequação da matéria ao tempo disponível e a outros fatores determinantes. Mas ao fragmentar o currículo, é preciso cuidado para que não se perca a noção de conjunto da matéria. Uma programação compartimentalizada em unidades semi-independentes corre 0 risco de pulverizar essa visão da totalidade, tornando o currículo um quebra-cabeças incongruente aos olhos dos alunos. Privados de elementos de ligação entre os assuntos estudados, os alunos podem ter dificuldades em resolver problemas e aprender coisas novas que envolvam o recurso a vários tópicos de uma vez.

Também aqui não funciona o argumento de que o aluno deve esperar, pois somente com o tempo é que poderá vir a ter a visão de totalidade do que foi estudando ao longo de todos os seus muitos anos escolares. Admitir isso seria transferir o problema, sem ao menos tentar resolvê-lo. Ao invés de esperar a passagem do tempo, pode-se, com o recurso à História da Matemática, distanciar-se do momento presente para obter essa perspectiva histórica que desejamos. O grande obstáculo para adquirir a visão de totalidade não está no limite do tempo, mas sim na tendência generalizada de extrapolar - para o passado ou para o futuro - o ponto de vista do presente.

Ao apresentar um tópico determinado de Matemática elementar, pode-se optar por uma abordagem baseada num conceito definido de rigor, que talvez nada tenha a ver com o nível de rigor próprio daquele assunto específico. De acordo com as análises desenvolvidas no Item 1 desse Capítulo 3, vimos que a Matemática passou e passa por um processo paulatino de formalização. Os assuntos estudados no nível elementar não surgiram necessariamente com o mesmo nível de formalização com que são apresentados hoje, e nada indica que esse nível de rigor permanecerá em voga no futuro. Se a historicidade do rigor é algo patente nos estudos históricos (ainda que se possa dizer que haja uma certa tendência na sua variação), não se pode querer tomar o conceito atual de rigor como padrão universal. É claro que não nos estamos referindo aqui à pesquisa em Matemática, mas sim ao ensino da Matemática elementar. Nesse caso, a tendência a extrapolar e a aplicar a todos os momentos do currículo um tratamento uniforme simplesmente destrói toda possibilidade de visualização em conjunto da matéria por parte do aluno. A Lógica Formal, a alma da Matemática sistematizada, estabelece ligações entre os tópicos que são visíveis apenas pelo especialista, e muitas vezes nem mesmo o Professor encarregado de dar a matéria tem acesso a essa visão.

O distanciamento propiciado pelo recurso à História da Matemática não significa um desvio no programa para realizar passeios históricos com a classe. O que é necessário é que se dê o passo da compreensão, no sentido que Marrou aplica ao trabalho do historiador ${ }^{264}$, para não querer impor a todos os assuntos elementares da Matemática um padrão uniforme de tratamento, baseado numa idéia invariável de rigor. Respeitar o nível lógico de cada tópico, para levar os alunos a construir um conhecimento matemático que possua relevo, e não seja uma indistinta seqüência uniforme de regras.

\footnotetext{
263 BOYER, Carl Benjamin. História da Matemática. Trad. de Elza F. Gomide. São Paulo, Edgard Blucher, 1974, 488 p., p. 344

264 Cf. Parte 1, Capítulo 1, nota 11
} 
A dificuldade de lidar com a questão das aplicações práticas do conhecimento matemático elementar também é decorrente dessa falta de visão de totalidade. Para que serve isso?, pergunta-se um aluno diante de um assunto específico de Matemática elementar. Algumas vezes, a resposta a esse tipo de pergunta se reduz a mostrar uma aplicação determinada daquele conhecimento matemático. Outras vezes, no entanto, pode tratar-se de uma verdadeira ruptura entre a Matemática e as aplicações práticas. Essas rupturas fazem parte da própria natureza do conhecimento matemático, uma vez que a Matemática não é uma arte técnica, mas uma Ciência autêntica.

Dedicaremos o restante desse item para analisar de modo mais concreto a questão das aplicações práticas, entendendo ser esse um exemplo determinante das vantagens do recurso à História para obter a visão de totalidade.

A visão da Matemática enquanto uma Ciência não é coisa que se forme desde o início do ensino elementar. Muitas vezes, também por causa disso, é conveniente mostrar aos alunos o maior número de aplicações possível de um dado conhecimento. Para isso é também útil o recurso à História da Matemática, grande fonte de exemplos práticos e de aplicações em vários níveis. Mas a função insubstituível da História surge quando é preciso mostrar a Matemática a partir de uma certa distância, de modo que se compreenda o fato de que ela não é um conjunto de regras para resolver problemas práticos. Referindo-se às rupturas entre teoria e prática, explica Machado que as aplicações da Matemática resolvem apenas certos casos de rupturas, acrescentando:

Há outras situações, no entanto, em que as rupturas realmente existem e desempenham papel fundamental em termos de ensino: elas representam a possibilidade de ultrapassagem do senso comum, da experiência imediata. Elas podem representar, ainda, uma reelaboração, no nível das concepções, que conduz a uma transposição dos limites do conhecimento estabelecido, uma visão do mar que só se consegue da gávea, nunca com os pés no chão do convés ${ }^{265}$.

Ou seja, essa descontinuidade entre a Matemática e as aplicações práticas, que pode surgir no ensino, é reflexo de uma realidade patente no estudo da evolução histórica da Matemática. A observação atenta de um período histórico suficientemente longo mostra que a Matemática às vezes se encaminha para uma direção aparentemente distante da prática, e mesmo lá encontra aplicações inesperadas; e outras vezes, um estudo com fins práticos acaba deixando de ser prático com a passagem do tempo.

Uma imagem pode ser aqui utilizada para tentar mostrar o que queremos dizer. Suponhamos que, ao invés de se assistir normalmente a um desenho animado, alguém tenha a idéia de olhar um por um os quadros estáticos que o compõem. Se, além disso, o fizesse lentamente, digamos olhando cinco ou seis quadros por semana, certamente teria grandes dificuldades para manter o interesse e sobretudo a compreensão da ação que se desenrolaria rapidamente, caso os quadros fossem mostrados em seqüência, na velocidade apropriada ao processo de animação.

Essa imagem serve para nos dar uma certa idéia do que ocorre habitualmente no ensino de Matemática elementar. Em cada aula se trabalha com algum tópico de modo independente, e fica muito difícil para o aluno obter uma visão da Matemática como um todo articulado. Embora não se trate apenas de assistir à Matemática, mas de estudá-la com razoável profundidade, ainda assim é válida a imagem do desenho animado. Com a animação da cena, é possível ir e voltar, parando em diversas situações o tempo que for necessário, sem perder a noção do que está de fato acontecendo. Mas sem animação não há visão de conjunto da cena viva.

Uma Matemática viva, como disse Cajori266, pode ser mostrada aos alunos quando se faz uso da História da Matemática. A própria idéia de que a Matemática tem história já por si só oferece uma perspectiva nova para o ensino da Matemática. Dizer que algo tem história significa olhá-lo em ação ao longo do tempo. Significa também recuar até uma certa distância para obter essa visão ampla. Um homem navegando um rio pode não ver o traçado percorrido por esse rio. Se subir até uma certa altura, então pode observarIhe as sinuosidades todas. Esse afastamento é imprescindível para se obter a visão da

265 MACHADO, Nílson José. Matemática e Língua Materna: Análise de uma Impregnação Mútua. São Paulo, Cortez, 1990. 169 p., p. 67

266 Cf. nota 3 da Introdução 
totalidade. O distanciamento propiciado pela História é, assim, fundamental para se obter uma visão de conjunto do edifício matemático que se almeja construir no ensino elementar. Com o recurso à História, pode-se compreender muito melhor a razão de ser de tópicos específicos da Matemática elementar.

Essa visão abrangente dificilmente pode ser adquirida sem o recurso à História da Matemática. A razão de ser da Matemática não se reduz em absoluto a um pragmatismo direto. O caráter de imprevisibilidade do progresso científico que Boyer identifica no desenvolvimento da Matemática é a contrapartida de sua indeterminação histórica ${ }^{267}$. O estudo da evolução da Matemática como um todo fornece, portanto, a cada tópico do currículo, uma razão de ser, uma utilidade que transcende a sua possível aplicação prática imediata. Conforme exemplificam Kleiner e Avital,

é irrefutável que sistemas criados por razões puramente matemáticas, sem pensamento de aplicações, posteriormente tornaram-se extremamente úteis. Por exemplo, as secções cônicas foram descobertas pelos gregos no quarto século a.C. como uma resposta a problemas de Matemática "pura". Dois mil anos mais tarde, Kepler mostrou que a órbita de um planeta é uma elipse com o Sol num dos focos, e Galileo mostrou que a trajetória dos projéteis é parabólica. Várias geometrias não euclidianas foram inventadas na metade do século XIX e, novamente, não foram motivadas por considerações físicas. Einstein usou uma modificação de uma tal geometria não-euclidiana na formulação de sua teoria geral da relatividade em $1916^{268}$.

A relação de exemplos sugerida por Kleiner e Avital poderia ser ainda mais alongada, mas basta para mostrar que não se pode medir o valor de um dado conhecimento matemático apenas pela sua aparente falta de aplicação. O estudo da História da Matemática leva à essa conclusão, que foi a mesma a que chegou Wilder ao final de sua pesquisa sobre a evolução dos conceitos matemáticos ${ }^{269}$. Após percorrer toda a História dos principais conceitos matemáticos, Wilder chega a elaborar o que chamou de Carta Magna, que recolhe sua conclusão acerca do critério de avaliação da produção criativa em Matemática:

Em vista do fato de que a força e utilidade da Matemática aumentaram na medida em que seus padrões conceituais tornaram-se mais e mais abstratos, parece justificável formular o que poderia ser denominado a Carta Magna do trabalhador criativo neste campo:

Não deve ser estabelecido limite algum à natureza ou caráter intrínseco da conceitualização, além do que pode ser imposto pelo mérito científico de suas conseqüências. $O$ julgamento acerca do mérito científico deve ser post facto. Em particular, um conceito não será rejeitado devido a critérios tão vagos como "irrealidade" ou devido as modo pelo qual ele foi elaborado 270

Essa facilidade de realizar giros panorâmicos percorrendo a História da Matemática, identificando com clareza a dimensão da liberdade da criação da Matemática e ao mesmo tempo descortinando sua real aplicação prática, é fruto principal do contato com os livros do tipo cronológico. A visão de conjunto que esse tipo de obra propicia permite compreender a relação sutil entre a gratuidade da invenção matemática e seu valor enquanto passível de aplicações práticas. É justamente por não se perderem em análises de pormenores que os livros cronológicos possibilitam o afastamento necessário para olhar a Matemática como um todo.

Esse é o "veio de ouro" das Histórias da Matemática do tipo cronológico, do ponto de vista de sua utilização didática para ensinar Matemática elementar. Essa visão global justifica também que em quase todos os livros desse tipo existam quadros de civilizações, localizando as civilizações ao longo do tempo e a linhas principais de passagem do conhecimento matemático.

267 Cf. nota 26 da Parte 3, Capítulo 1

268 KLEINER, Israel \& AVITAL, Shmuel. The Relativity of Mathematics. In: The Mathematics Teacher. Volume 77, Number 7, October 1984, pp. 554-559, p. 557

269 WILDER, Raymond Louis. Evolution of Mathematical Concepts. New York, John Wiley, 1973. 216 p.

270 Ibid., p. 203 
Outro quadro característico dos livros cronológicos é a tabela de correlação de acontecimentos, que relaciona as datas dos acontecimentos matemáticos mais importantes com outras datas historicamente significativas. Smith ${ }^{271}$, por exemplo, usa tipos de letras diferentes para acontecimentos históricos e matemáticos, destacando seu grau de importância. Vejamos um trecho dessa tabela, relacionando algumas obras importantes com outras datas:

\begin{tabular}{|cl|}
\hline 1490 & Johann Widman. Álgebra, aritmética \\
1491 & Calandri. Aritmética. \\
1492 & Pellos. Aritmética \\
& \multicolumn{1}{c|}{ Lanfreducci. Aritmética } \\
& \multicolumn{1}{c|}{ Colombo descobre a América } \\
1493 & Maximiliano I, Imperador da Alemanha \\
1494 & Pacioli. Matemática Geral \\
\hline
\end{tabular}

271 Cf. SMITH, David Eugene. History of Mathematics. Boston, Ginn and Co., 1923. 2 v. Vol. I, 596 p., p. 561 
Já Boyer272 oferece uma tabela com duas colunas, a da esquerda assinalando acontecimentos matemáticos e a da direita outros fatos históricos e ligados a outras ciências. Eis um trecho:

\section{Al-Khowarismi: Álgebra \\ 901 Morte de Thabit ibn-Qurra}

998 Morte de abu'I-Wefa

1037 Morte de Avicena

1039 Morte de Alhazen

1048 Morte de al-Biruni

\section{Morte de Carlos Magno}

$\begin{aligned} 910 & \text { Abadia Beneditina de Cluny } \\ 987 & \text { Ascensão de Hugo Capeto } \\ 999 & \text { Gerbert torna-se Papa Silvestre II } \\ 102 & \text { Escola em Chartres } \\ 8 & \end{aligned}$

106 Batalha de Hastings

6

109

6

110 Henrique I de Inglaterra coroado

\section{Nascimento de Bháskara} 0

Conforme já dissemos, os livros por assunto tem a função especial de fornecer indícios para a construção do caminho lógico adequado ao nível dos alunos, de modo que os tópicos específicos adquiram significado aos seus olhos. Esses componentes do valor didático da História da Matemática não são próprios de um livro cronológico, pois não fornecem diretamente a seqüência de elaboração de nenhum assunto determinado. Não basta, tampouco, utilizar fragmentos da História cronológica a respeito de um assunto específico, pois, uma vez fragmentado, esse tipo de texto acaba perdendo o sentido. É a mesma sensação de quem olha uma tela de televisão com lente de aumento: apenas enxerga pontos coloridos, que nada informam do conjunto da cena. Assim como deve-se manter uma certa distância do aparelhos de televisão para assistir adequadamente, é preciso olhar a História da Matemática com suficiente distanciamento para obter a visão de conjunto que um livro cronológico é, como nenhum outro, capaz de propiciar.

Tomemos, como exemplo, o item 22 do livro cronológico de Boyer ${ }^{273}$, intitulado Matemáticos da Revolução Francesa. Por ele obtemos essa visão ampla de que viemos falando, a qual permite reflexões interessantes sobre a Matemática dita prática. $\mathrm{O}$ item trata fundamentalmente de fornecer um panorama comparativo da vida e obra de seis grandes matemáticos contemporâneos à Revolução Francesa ${ }^{274}$, de comportamentos políticos diversos:

A queda da Bastilha em 1789 encontrou nossos seis homens divididos em duas categorias: os três "eles" (Lagrange, Laplace e Legendre) não tomaram parte significativa no desenrolar dos acontecimentos políticos que se seguiram; os outros três (Carnot, Condorcet e Monge) receberam bem a mudança e desempenharam papéis definidos nas atividades revolucionárias. Mas homens de ambos os grupos participaram ao menos em um projeto matemático durante a Revolução 275 .

A aplicação de três matemáticos à prática política poderia sugerir à primeira vista que sua produção matemática tivesse um cunho mais prático, enquanto o trabalho dos outros três permanecesse num nível mais teórico. Essa errônea impressão é desmentida pela análise das suas obras:

\footnotetext{
272 Cf. BOYER, Carl Benjamin. História da Matemática. Trad. de Elza F. Gomide. São Paulo, Edgard Blucher, 1974, 488 p., p. 468 


\section{de motivação utilitária276. \\ Olhando a obra desses seis homens observa-se a falta \\ Laplace é o que mais se aproxima de um matemático aplicado277,} pesquisando a teoria das probabilidades e a mecânica celeste. Lagrange trabalhou com a teoria das funções e sua maior contribuição foi sobre o cálculo de variações ${ }^{278}$. Além disso, dedicou-se ao ensino, tendo contribuído para a elaboração de currículos em vários níveis, da École Normale à École Polytechnique ${ }^{279}$. Legendre aplicou-se a temas como equações diferenciais, Cálculo, teoria das funções, teoria dos números e Matemática aplicada, fornecendo alguns instrumentos básicos da análise muito úteis também para a Física 280 .

Quanto aos outros três, mais engajados politicamente, não se pode dizer que tivessem uma atividade matemática essencialmente prática. Monge trabalhou com geometria descritiva e analítica, temas de grande alcance, tanto do lado puro quanto do aplicado 281 , sendo considerado um dos fundadores da geometria pura moderna 282 . Carnot, de intensa vida política, dedicou-se matematicamente ao estudo da "metafísica do cálculo infinitesimal"283, que não era propriamente um tema de estudo de matemática aplicada. Condorcet trabalhou com Cálculo e com probabilidades e estatística, acabando vítima da própria Revolução que de início apoiara: foi encontrado morto no dia seguinte a sua prisão.

Os estudos históricos revelam, portanto, que a aplicabilidade prática imediata do conhecimento matemático não é questão trivial. Não se pode julgar o valor da Matemática analisando apenas esse fator. É preciso afastar-se o suficiente para obter, com o estudo da História da Matemática, a visão da totalidade. Boyer encerra seu item de uma forma que pode ser utilizada analogicamente como um fecho desse trabalho:

Mais de um século e meio se passou desde os dias de que estivemos falando, e podemos olhar para o período sem paixão. Uma lição que se pode tirar é que as coisas que realmente contam na matemática e que têm influência duradoura não são as que se inspiram em utilitarismo imediatista. Mesmo em tempos de crise são as coisas do "espírito" (no sentido francês) que mais contam, e essas são talvez melhor transmitidas pelos grandes mestres ${ }^{284}$.

\footnotetext{
276 lbid., p. 346

277 Cf. Ibid., p. 347

278 Cf. Ibid., p. 360

279 Cf. Ibid., p. 359

280 Cf. Ibid., p. 357

281 Cf. Ibid., p. 349

282 Cf. Ibid., p. 352

283 Cf. Ibid., p. 354

284 lbid., p. 364
} 


\section{Conclusões}

O luar brilhava na face cinzenta
da rocha, mas mesmo assim, durante algum
tempo, eles não conseguiram ver mais nada.
Depois, lentamente, apareceram linhas tênues na
superfície por onde as mãos do feiticeiro tinham
passado, linhas que pareciam finas veias de prata
a sulcar a pedra. Ao princípio, dir-se-iam pálidos
fios de teias de aranha, tão finos que só brilhavam
interruptamente nos pontos onde o luar incidia;
mas, pouco a pouco, foram-se tornando mais
grossos e nítidos, até se poder adivinhar o seu
desenho.

Tolkien 285

Assim como na cena sugerida pela epígrafe, esperamos ao fim desse trabalho ter contribuído para a formação de um esboço de algumas das linhas mestras para um estudo do valor didático da História da Matemática. Abordamos alguns daqueles que consideramos fatores importantes para delinear uma concepção do recurso à História da Matemática não como mero acessório didático, mas como verdadeiro definidor de estratégias pedagógicas. Apresentaremos a seguir um apanhado dessas linhas principais, para servir de conclusão a esse trabalho e de pauta para futuras análises sobre a Arte de Contar.

Uma tarefa fundamental do historiador parece residir na compreensão das fontes, através da interpretação de sinais e indícios de caráter singular, numa ação criadora. As explicações elaboradas pelo historiador são sempre limitadas principalmente pelo acesso às fontes de que dispõe o historiador, a partir das quais pode tentar captar a lógica interna das formas de pensar, das mentalidades do passado. No caso específico da História da Matemática, para se apreender a lógica do processo de criação da Matemática, é preciso recorrer a várias espécies de fontes, escritas e não-escritas. Mesmo entre os documentos escritos que se podem utilizar, nem todos são intencionalmente históricos, o que constitui uma dificuldade a mais.

O conhecimento sobre a História da Matemática Pré-Helênica, por exemplo, é construído, em larga medida, com base em achados arqueológicos, já que não existe uma tradição linear ligando essas Civilizações a nossa. A partir das primeiras sistematizações gregas, a pesquisa histórica pode seguir o fluxo da Tradição Greco-Latina, auxiliada pela produção dos autores latinos da segunda metade do primeiro milênio e pelos autores e tradutores árabes, cujas obras são de grande importância para a compreensão da cultura helênica. A partir do ano 1000, com os trabalhos de Gerbert e seus alunos, encontramos indícios de um interesse crescente pela pesquisa matemática, com um conseqüente resgate da cultura Greco-Latina através de manuscritos árabes e latinos. Já no século XII, um verdadeiro renascimento nas Artes, na Ciência e na Cultura começa a florescer na Europa, gerando a produção de obras muito úteis para a História da Matemática. Com a utilização da imprensa, a partir do século XV, multiplicam-se as obras matemáticas, e nos séculos seguintes encontramos as primeiras obras impressas específicas de História da Matemática, culminando com a obra de Montucla em 1758, modelo de livro do tipo cronológico.

Além do modelo cronológico de Montucla, levado às últimas conseqüências na obra de Moritz Cantor em 1880, outros tipos de livro histórico irão surgir. Principalmente após a obra por assunto de Smith em 1923, encontramos novos livros trazendo biografias e outros com estudo por civilizações. Cada um desses tipos de livros pode ter certas vantagens, sendo a caracterização de cada um algo muito valioso para quem estiver interessado em estudar o valor didático da História da Matemática.

Uma vez conhecido o modo de acesso à História da Matemática, trata-se de estudar o valor de sua aplicação didática, que se apresenta com diversos componentes. Um componente importante do valor didático da História da Matemática é que nela se podem apreender caminhos lógicos para a construção de demonstrações pedagógicas em sala de aula. Os estudos históricos deixam muito clara uma distinção entre a forma lógica inicial,

285 TOLKIEN, John Ronald Reuel. O Senhor dos Anéis. Trad. de Fernanda Pinto Rodrigues. $3^{\mathrm{a}}$ ed. Lisboa, Publicaç/Ees Europa-América, 1966. 3 v., v. I, p. 330. 
presente nas origens da Matemática, e sua posterior e paulatina sistematização. A lógica natural, presente na construção histórica do conhecimento matemático, está novamente presente no processo de aprendizagem da Matemática elementar. Para justificar esse fato, por vezes se faz referência à hipótese do paralelismo onto-filogenético, sugerindo que o processo de ensino/aprendizagem deva se pautar pela seqüência de construção do conhecimento fornecida pela História. Essa hipótese, porém, não é condição necessária para justificar o valor didático da História da Matemática. Inclusive, tomada literalmente, esse paralelismo pode conduzir a absurdos, pois não existe um princípio claro que determine a evolução da Matemática como um todo. Mas cada tópico específico pode ser logicamente estruturado segundo a Matemática em construção, sendo os livros de História da Matemática por assunto os mais apropriados para esse tipo de utilização pedagógica.

Outro componente advém do estudo da questão do significado da linguagem simbólica da Matemática. Sua aparência por vezes abstrusa é causa freqüente de aversão pelo aprendizado da Matemática, chegando inclusive a gerar uma espécie de analfabetismo matemático. A própria motivação fica comprometida, se não se fornecem ao aluno condições de compreender a linguagem matemática, construindo o significado das noções que deve aprender. Mas uma vez que a linguagem da matemática sistematizada apresenta relações sintáticas distantes da semântica dos símbolos que emprega, é preciso resgatar as relações semânticas presentes na construção histórica da Matemática para que o aluno possa ter acesso ao significado desses símbolos. Com um ensino significativo, também se fortalece a motivação para o aprendizado, colaborando na superação da dicotomia entre técnica e significado.

É fundamental ainda considerar o valor do conhecimento histórico para proporcionar uma visão abrangente da Matemática elementar. Dentro do currículo elementar, pode ocorrer um isolamento entre os diversos assuntos, com a conseqüente perda da noção de conjunto do que é estudado. É possível, no entanto, através do recurso à História, distanciar-se do momento atual e evitar, com a perspectiva histórica, a tendência generalizada de extrapolar - para o passado ou para o futuro - o ponto de vista do presente, muitas vezes imbuído de uma idéia invariável de rigor. Esse distanciamento propiciado pela História permite compreender que a Matemática está em contínuo processo de formalização. O reconhecimento da historicidade do rigor impede que se tome o conceito atual de rigor como padrão universal, levando a respeitar o nível de formalização de cada tópico. Como conseqüência, os alunos podem construir um conhecimento matemático que possua relevo, e que não seja uma indistinta seqüência uniforme de regras.

Por outro lado, a dificuldade de lidar com a questão das aplicações práticas do conhecimento matemático também pode ser melhor superada pelo recurso à História, que é fundamental para se compreender que ter significado não é o mesmo que ter aplicações práticas. Pela visão de totalidade que fornece a História se aprende a dar valor também àqueles tópicos que não apresentam aplicações práticas imediatas, pois a razão de ser da Matemática não se reduz em absoluto a um pragmatismo direto. Os estudos históricos revelam que a Matemática às vezes se encaminha para uma direção aparentemente distante da prática, e mesmo lá encontra aplicações; outras vezes, um estudo inicialmente com objetivos práticos acaba deixando de ser prático com a passagem do tempo. Essa visão abrangente dificilmente pode ser adquirida sem o recurso à História da Matemática.

É preciso afastar-se o suficiente para obter, com o estudo da História da Matemática, a visão da própria natureza do conhecimento matemático, uma vez que a Matemática não é uma arte técnica, um conjunto de regras para resolver problemas práticos, mas uma Ciência autêntica. Com isso, torna-se possível que o aluno descubra a dimensão de liberdade da criação da Matemática e ao mesmo tempo compreenda melhor sua aplicabilidade real. O distanciamento propiciado pela História é, assim, imprescindível para se obter uma visão de conjunto do edifício matemático que se almeja construir no ensino elementar.

De volta à cena da epígrafe, podemos completar essas conclusões revelando que o desenho que se adivinhava na rocha significava para os protagonistas a possibilidade de prosseguir, através das montanhas, a longa jornada que mal acabavam de começar. Também nós julgamo-nos assim diante das questões levantadas por esse trabalho, que podem representar o ponto de partida de muitos estudos sobre o valor didático da História da Matemática, através de inúmeros caminhos, que esperamos ter contribuído para apontar. Para nós, em síntese, fazer uso da História da Matemática não implica necessariamente contar a História da Matemática aos alunos. A abordagem que 
denominamos de Arte de Contar consiste em estruturar o conteúdo da matéria a ser ensinada à luz da sua evolução histórica. Um ensino assim planejado, a nosso ver, seria mais significativo, por basear-se numa lógica que é acessível aos alunos, possibilitando-lhes uma visão da totalidade do que é ensinado. Nossa intenção é seguir adiante por alguma das muitas linhas de pesquisa pertinentes à paisagem ampla desse tema, e esperamos contar com a companhia de muitos outros nesta viagem. 


\section{Apêndices}

\section{Experiências de Alguns Cursos de História da Matemática}

Recolhemos aqui, sucintamente, alguns dados referentes a cursos sobre História da Matemática planejados e ministrados pelo autor durante a realização desse trabalho. A preparação desses cursos foi de enorme valia para o aprofundamento no tema do trabalho. Ministrá-los para diversos grupos de alunos de $2^{0}$ e $3^{\circ}$ graus, bem como para professores em atividade, também serviu para levantar várias questões que serviram de base para aprofundamentos e análises posteriores.

Agradecemos de modo especial a Profa Dra Maria Ignez de Souza Vieira Diniz, Coordenadora do CAEM - Centro de Aperfeiçoamento do Ensino da Matemática -, pelo incentivo e total apoio à realização de todos os cursos, organizados sob sua coordenação. Resta agradecer também a todos os alunos e professores que assistiram aos cursos, participando ativamente e contribuindo de diversas formas com críticas, comentários e sugestões.

\section{Cursos para Professores de Matemática}

Foram ministrados três cursos de trinta horas sobre o tema História da Matemática, entre 1988 e 1990, inseridos no convênio entre a Secretaria de Educação do Estado de São Paulo e a Universidade de São Paulo, e promovidos pelo Centro de Aperfeiçoamento do Ensino da Matemática do Instituto de Matemática e Estatística.

Participaram de cada curso cerca de quarenta professores P-III (Habilitação Plena) da Rede Estadual de Ensino, provenientes de diversas escolas. Abaixo fornecemos um esboço das características de cada curso:

Curso 1. História da Matemática

De 20/08/88 a 24/09/88, cinco aulas de seis horas cada.

Programa:
1. Panorama da História Geral da Matemática
2. História da Aritmética
3. História da Álgebra
4. História da Geometria
5. Localização Histórica do Currículo Elementar de Matemática

Curso 2. História da Matemática como Recurso Pedagógico

De 20/10/89 a 08/12/89, oito aulas de 3 h45min cada.

Programa:

1. Por que estudar História da Matemática?

2. Origens da Matemática

3. O Papel da Formalização Grega

4. A Transmissão da Matemática via Tradição Latina e os Árabes

5. O Renascimento do Século XII

6. Prelúdio à Matemática Moderna

7. O lugar da História da Matemática na Proposta Curricular para o Ensino de Matemática da Secretaria de Educação de 1987

Curso 3. História da Matemática como Recurso Pedagógico

8. Exemplos Práticos e Avaliação de Livros e Materiais Didáticos

De 12/02/90 a 16/02/90, cinco aulas de seis horas cada.

Programa:

1. Introdução ao Estudo da História da Matemática como Recurso Pedagógico

2. Panorama Geral da História da Matemática

3. O Livro Didático e as Fontes da História da Matemática

4. Exemplos Práticos de Utilização da História em Sala de Aula

5. Conclusões acerca do Valor Didático da História da Matemática 


\section{Cursos para Alunos de 2。Grau}

Foram promovidos pelo CAEM seis cursos sobre História da Matemática, entre maio de 1988 e outubro de 1989, inseridos dentro da categoria de Cursos de Difusão Cultural, como parte do programa de abertura da Universidade à Comunidade. Assistiram aos cursos alunos provenientes de escolas públicas (estaduais e municipais) e particulares, em número variando entre 30 e 70 . Com duração de seis a nove horas, esses cursos constituíam-se de três aulas, ministradas nas dependências do IME-USP. O programa de cada curso não mudou substancialmente quanto à forma, embora o conteúdo variasse bastante, tendendo a uma maior aproximação com a realidade dos assistentes.

\section{Tema dos Cursos: História das Descobertas Matemáticas}

Programa Geral:

1. As Origens

-Primeiras Civilizações: Egito, China Mesopotâmia, Índia, Maias, Astecas

-O nascimento da Civilização Grega

2. A Estrutura Formal

- A Filosofia Clássica e a Ciência

- Escola Pitagórica, Academia de Platão, Museu de Alexandria

3. A Transmissão

-Os Manuscritos Medievais

-Os Árabes e as Escolas de Tradutores

-O Renascimento do Século XII

-A Renascença

\section{Cursos para Alunos do IME-USP}

O CAEM também promoveu alguns Cursos de Extensão Cultural sobre temas de História da Matemática abertos a alunos do próprio Instituto. Embora o assunto pudesse talvez interessar mais aos alunos do curso de Licenciatura, o fato é que houve inscrições de todos os cursos (Matemática Pura, Aplicada, Estatística e Computação), de semestres variados, desde recém-ingressantes até formandos e também alguns alunos do Programa de Pós -Graduação.

\section{Curso 1. História da Noção de Número}

De 23/08/90 a 20/09/90, quatro aulas de duas horas cada.

Programa:

1. Numeração Indígena

2. Egito, Mesopotâmia, China e Maias

3. Crise da Escola Pitagórica: os Incomensuráveis

4. Paradoxos da Continuidade

5. Apogeu da Filosofia Clássica na Grécia

6. Lógica e Gênese do Pensamento Científico

7. Axiomatização da Matemática

Curso 2. Oficina de Pesquisa em História da Matemática

De 27/09/90 a 25/10/90, quatro aulas de duas horas cada.

Programa:

1. Geometria Pré-Helênica

2. Geometria Sofista

3. Tales e Pitágoras

4. Euclides de Alexandria

Curso 3. História das Fontes da História da Matemática

De 03/04/91 a 30/05/91, oito aulas de uma hora cada.

Programa:

1. Fontes da História da Matemática Pré-Helênica

2. Tradição Greco-Latina

3. De Boécio a Gerbert 


\author{
4. O Renascimento do Século XII \\ 5. Os Vários Tipos de Livros de História da Matemática \\ 6. Cronologias \\ 7. Por Assunto \\ 8. Biografias e Outros Tipos
}




\section{Bibliografia Geral}

AABOE, Asger. Episódios da História Antiga da Matemática. Trad. de João Pitombeira de Carvalho. Rio de Janeiro, Sociedade Brasileira de Matemática, 1984. 170 p.

ANDRÉ, Marli E.D.A. \& LÜDKE, Menga. Pesquisa em Educação: Abordagens Qualitativas. São Paulo, EPU, 1986. 99 p.

ARCHIBALD, Raymond Clare. Outline on the History of Mathematics. Ohio, Mathematical Association of America, 1941, $76 \mathrm{p}$.

ARISTÓTELES. Metafísica. Coleção "Os Pensadores". Vol. IV. $1^{\text {a }}$ ed. Trad. de Vicenzo Cocco. São Paulo, Abril Cultural, 1973.

BALL, Walter William Rouse. A Primer of the History of Mathematics. London, MacMillan and Co., 1930.149 p.

BELL, Eric Temple. Men of Mathematics. New York, Simon and Schuster, 1965. 590 p.

BLACKINGTON, Frank H. The Instrumental Value of Research on Logical Thinking. In: Theory into Practice. Vol. XII(5). December, 1973.

BOCHENSKI, Innocentius Marie. A Filosofia Contemporãnea Ocidental. Trad. de Antonio Pinto de Carvalho. 3a ed. São Paulo, EPU/EDUSP, 1975. 300 p.

BOCHENSKI, Innocentius Marie. Los Metodos Actuales del Pensamiento. Traducción de Raimundo Drudis Baldrich. 2a ed. Madrid, Rialp, 1958. 278 p.

BOLL, Marcel. As Etapas da Matemática. Lisboa, Europa-América, 1979. 166 p.

BOYER, Carl Benjamin. História da Matemática. Tradução de Elza F. Gomide. São Paulo, Edgard Blücher, 1974, 488 p.

BRONOWSKI, J. O Senso Comum da Ciência. São Paulo, EDUSP, 1977.

BÜHLER, Walter Kaufmann. Gauss: A Biographical Study. New York, Springler-Verlag, 1981. $208 \mathrm{p}$.

CAJORI, Florian. A History of Mathematical Notations. Chicago, The Open Court, 1928. 2 v. V. 1: Notations in Elementary Mathematics. 451 p.

CAJORI, Florian. A History of Mathematics. $2^{\mathrm{a}}$ ed. New York, The MacMillan Company, 1919, $516 \mathrm{p}$.

CANTOR, Moritz Benedict. Vorlesunger über Geschichte der Mathematik. Berlin, Verlag und Teubner, 1880-1908. 4 v.

CARAÇA, Bento de Jesus. Conceitos Fundamentais da Matemática. 9a ed. Lisboa, Sá da Costa, 1989. $318 \mathrm{p}$.

CERAM, C. W. Deuses, Túmulo e Sábios: o Romance da Arqueologia. Trad. de João Távora. $16^{\mathrm{a}}$ ed. São Paulo, Melhoramentos, 1982. 392 p.

CERVANTES, Miguel de. O Engenhoso Fidalgo Dom Quixote de la Mancha. Tradução de Viscondes de Castilho e Azevedo. São Paulo, Abril Cultural, 1978, 609 p.

COLLETTE, Jean-Paul. Historia de las Matemáticas. Traducción de Pilar González Gayoso. Mexico, Siglo Veintiuno, 1986, 2 v.

CONNELLY, F. M. Logical Reasoning in Science Education. In: Theory into Practice. Vol. XII(5). December, 1973.

COOLIDGE, Julian Lowell. Mathematics of Great Amateurs. Oxford, Claredon, 1950. 211 p.

COSTA, Manuel Amoroso. As Idéias Fundamentais da Matemática e Outros Ensaios. $3^{\mathrm{a}}$ ed. São Paulo, Convívio/EDUSP, 1981. 330 p. 
DINIZ, Maria Ignez de Souza Vieira et al. Proposta Curricular de Matemática para o CEFAM e Habilitação Específica para o Magistério. São Paulo, Secretaria de Educação/Coordenadoria de Estudos e Normas Pedagógicas, 1990. 257 p.

EUCLIDES. The Thirteen Books of Euclid's Elements. Trad. e com. por Thomas Little Heath. $2^{\mathrm{a}}$ ed. New York, Dover, 1956. 13v. em 3

EULER, Leonhard. Cartas a uma Princesa de Alemania sobre Diversos Temas de Física e Filosofía. Ed. de Carlos Mínguez Péres. Zaragoza, Universidad de Zaragoza, 1990. $613 p$.

EVES, Howard. An Introduction to the History of Mathematics. New York, Holt, Rinehart and Winston, 1969, $464 \mathrm{p}$.

GAMA, Ruy. História da Ciência e da Tecnologia. São Paulo, Queiroz/EDUSP, 1985. 286 p.

GILLINGS, Richard J. Mathematics in the Time of the Pharaohs. New York, Dover, 1972, 288 p.

GILSON, Étiene. Lingüística y Filosofía. Madrid, Editorial Gredos, 1974. 334 p.

GINZBURG, Carlo. Sinais: Raízes de um Paradígma Indiciário. Apud: Mitos, Emblemas e Sinais: Morfologia e História. Trad. de Federico Carotti. São Paulo, Companhia das Letras, 1989, 281 p., pp. 143-179

GROZA, Vivian Shaw. A Survey of Mathematical Elementary Concepts and their Historical Development. New York, Holt, Rinehart and Winston, 1968, 327 p.

HEATH, Thomas Litle. A History of Greek Mathematics. New York, Dover, 1981. 2 v.

HEATH, Thomas Little. Diophantus of Alexandria: a Study in the History of Greek Algebra. New York, Dover, 1964. 387 p.

HERSH, Reuben \& DAVIS, Philip J. A Experiência Matemática. 4a ed. Trad. de João Bosco Pitombeira. Rio de Janeiro, Francisco Alves, 1989. 481 p.

HERSH, Reuben \& DAVIS, Philip J. O Sonho de Descartes. Trad. de Márcio C. Moura. Rio de Janeiro, Francisco Alves, 1988. 335 p.

HOFFER, Alan. Geometry is More than Proof. IN: The Mathematics Teacher. V. 74(1): pp. 11-8. January 1981

IEZZI, Gelson et. al. Coleção Fundamentos da Matemática Elementar. São Paulo, Atual, 1977-81. $10 \mathrm{v}$.

IFRAH, Georges. Os Números: a História de uma Grande Invenção. Trad. de Stella Maria de Freitas Senra. Rio de Janeiro, Globo, 1989, 367p.

IMENES, Luiz Márcio. Um Estudo sobre o Fracasso do Ensino e da Aprendizagem da Matemática. Dissertação de Mestrado. Rio Claro, UNESP, 1989.

INFELD, Leopold. Whom the Gods Love: the Story of Evariste Galois. New York, McGrawHill, 1948. 323p.

ISIDORO DE SEVILHA. Etimologías. Versão bilingue (Latim/ Espanhol) de José Oroz Reta e Manuel-A. Marcos Casquero. Madrid, Biblioteca de Autores Cristianos, 1982. Livro III (De Mathematica), pp. 422-481

JAKUBOVIC, José \& LELLIS, Marcelo. Matemática na Medida Certa (6a série). São Paulo, Scipioni, 1990.

JOLIVET, Regis. Curso de Filosofia. Rio de Janeiro, AGIR, 1968.

KLEINER, Israel \& AVITAL, Shmuel. The Relativity of Mathematics. In: The Mathematics Teacher. Vol. 77(7). October 1984. pp. 554-9.

KLINE, Morris. O Fracasso da Matemática Moderna. São Paulo, IBRASA, 1976.

KNEALE, Willian \& KNEALE, Martha. O Desenvolvimento da Lógica. 1a ed. Trad. de M. S. Lourenço. Lisboa, Fundação Calouste Gulberkian, 1972, 770 p. 
LAKATOS, IMRE. Pruebas y Refutaciones: la Lógica del Descubrimiento Matematico. Madrid, Alianza Editorial, 1986.

LATTIN, Harriet Pratt (Ed.). The Letters os Gerbert. New York, Columbia University Press, 1961. $412 \mathrm{p}$.

LAUAND, Luiz Jean. Educação, Teatro e Matemática Medievais. São Paulo, Perspectiva/EDUSP, 1986, $117 \mathrm{p}$.

LAUAND, Luiz Jean. O Ensino de Matemática e sua Dimensão Filosófica e Social. In: Educação \& Matemática. 1978(2), Set-Dez, pp. 28-39

LAUAND, Luiz Jean. O Que é uma Universidade? Sào Paulo, EPU/EDUSP, 1989.

LORENZO, Javier de. Introducción al estilo matematico. Madrid, Tecnos, 1989, 209 p.

LORIA, Gino. Guida allo Studio della Storia delle Matematiche. $2^{\mathrm{a}}$ ed. Milano, Ulrico Hoepli, 1946. 385 p.

LUCCI, Elian Alabi. História Geral - 10 Grau. São Paulo, Savaiva, 1983. 2 v.

LÓPEZ, Roberto J. Nuevas Tendencias en la Historiografía: la Vuelta al Arte de Contar. Madrid, ACEPRENSA, 16 Marzo 1988, servício 37/88

MACHADO, Nílson José. Matemática e Língua Materna: Análise de uma Impregnação Mútua. São Paulo, Cortez, 1990. 169 p.

MACHADO, Nílson José. Matemática e Realidade. São Paulo, Cortez, 1987, 103 p.

MAHONEY, Michael Sean. The Mathematical Career of Pierre de Fermat (1601-1665). New Jersey, Princeton University Press, 1973. 419 p.

MARROU, Henri-Irénée. Sobre o Conhecimento Histórico. Tradução de Roberto Cortes de Lacerda. Rio de Janeiro, Zahar Editores, 1978, 265 p.

MIDONICK, Henrietta O. (Ed.) The Treasury of Mathematics. New York, Philosofical Library, 1965. $820 \mathrm{p}$.

MIKAMI, Yoshio. The Development of Mathematics in China and Japan. New York, Chealsea, 1913, 347 p.

MOLES, Abrahan Antoine. A Criação Científica. São Paulo, Perspectiva/EDUSP, 1971.

MONTUCLA, Jean Étienne. Histoire des Mathématics. Paris, Jombert, 1758. 2 v.

NEEDHAM, Joseph. Science and Civilization in China. Cambridge, University Press, 1959. 3 $\mathrm{V}$.

NEUGEBAuER, Otto e SACHS, A. Mathematical Cuneiform Texts. New Haven, Conn. Yale University Press, 1945.

NUNES, Ruy Afonso da Costa. História da Educação. São Paulo, EPU/EDUSP, 1979-81. 4 v.

OSBORNE, Ala R. \& REGAN, Gerald M. Logical Reasoning: an Educational Goal. In: Theory into Practice. Vol. XII(5). December, 1973.

PIAGET, Jean \& GARCIA, Rolando. Psicogênese e História das Ciências. Lisboa, Publicações Dom Quixote, 1987, 247 p.

PIATELLI-PALMARINI, M. (Org.). Teorias da Linguagem/Teorias da Aprendizagem. São Paulo, Cultrix/EDUSP, 1983. $455 \mathrm{p}$.

PIERRO NETTO, Scipione di. Matemática: Conceitos e Histórias. São Paulo, Scipioni, 1991. $4 \mathrm{v}$.

SANFORD, Vera. A Short History of Mathematics. New York, Houghton Mifflin, 1930. 402 p.

SEGAL, S. L. Mathematical Anxiety: Real or Imaginary? In: Ciência e Cultura. 36(1), Janeiro de 1984. pp. 9-15

SHAKESPEARE. A Megera Domada. Ato I (palavras de Trânio). Trad. de Millôr Fernandes. Porto Alegre, L \& PM Editores, 1979, 164 p. 
SMITH, David Eugene \& KARPINSKI, L. C. The Hindu-Arabic Numerals. Boston, Ginn and Company, 1911.

SMITH, David Eugene \& MIKAMI, Yoshio. A History of Japanese Mathematics. Chicago, 1912.

SMITH, David Eugene. A Source Book in Mathematics. New York, Dover, 1959. 2 v.

SMITH, David Eugene. History of Mathematics. Boston, Ginn and Co., 1923. 2 v.

STRUIK, Dirk. J. A Concise History of Mathematics. London, Dover, 1948. 299 p.

TOLKIEN, John Ronald Reuel. O Senhor dos Anéis (3 vols.). Trad. de Fernanda Pinto Rodrigues. $3^{\mathrm{a}}$ ed. Lisboa, Publicações Europa-América, 1966

VAN DER WAERDEN, Bartel Leenert. A History of Algebra. Berlin, Springer-Verlag, 1985, $271 \mathrm{p}$.

VAN DER WAERDEN, Bartel Leenert. Geometry and Algebra in Ancient Civilizations. Berlin, Springer-Verlag, 1983. $223 \mathrm{p}$.

WILDER, Raymond Louis. Evolution of Mathematical Concepts. New York, John Wiley, 1973. $216 \mathrm{p}$.

World Who's Who in Science. Chicago, Marquis, 1968. 1855 p.

YOUNG, Laurence C. Mathematician and Their Times. Amsterdan, Nort-Holland, 1981. 


\section{Bibliografia Específica Sugerida 1.Cronologias}

ARCHIBALD, Raymond Clare. Outline on the History of Mathematics. Ohio, Mathematical Association of America, 1941, $76 \mathrm{p}$.

BABINI, J. y PASTOR, J. Rey. Historia de la Matemática. Buenos Aires, Espasa-Calpe Argentina, 1952. $368 \mathrm{p}$.

BALL, Walter William Rouse. A Primer of the History of Mathematics. London, MacMillan and Co., 1930.149 p.

BOYER, Carl Benjamin. História da Matemática. Tradução de Elza F. Gomide. São Paulo, Edgard Blücher, 1974, 488 p.

BOYER, Jacques. Histoire des Mathématiques. Paris, Gauthier-Villars, 1900. 260 p.

CAJORI, Florian. A History of Mathematics. $2^{\mathrm{a}}$ ed. New York, The MacMillan Company, 1919, $516 \mathrm{p}$.

CANTOR, Moritz Benedict. Vorlesunger über Geschichte der Mathematik. Berlin, Verlag und Teubner, 1880-1908. 4 v.

COLERUS, Egmont. Historia de la Matemática: De Pitágoras a Hilbert. Buenos Aires, Progresso y Cultura, 1943. $353 \mathrm{p}$.

COLLETTE, Jean-Paul. Historia de las Matemáticas. Traducción de Pilar González Gayoso. Mexico, Siglo Veintiuno, 1986. 2 v.

EVES, Howard. An Introduction to the History of Mathematics. New York, Holt, Rinehart and Winston, 1969, $464 \mathrm{p}$.

FINK, Karl. A Brief History of Mathematics. Chicago, The Open Court, 1910. 333 p.

HOEFER, Ferdinand. Histoire des Mathématiques. Paris, Libraire Hachette, 1874. 602 p.

LORIA, Gino. Storia delle Matematiche. Milano, Ulrico Hoepli, 1929. 3 v.

MARIE, M. Maximilien. Histoire des Sciences Mathématiques et Physiques. Paris, GauthierVillars, 1883. $12 \mathrm{v}$.

MONTUCLA, Jean Étienne. Histoire des Mathématics. Paris, Jombert, 1758. 2 v.

SMITH, David Eugene. History of Mathematics. Boston, Ginn and Co., 1923. 2 v. Vol. I, 596 p.

STRUIK, Dirk. J. A Concise History of Mathematics. London, Dover, 1948. 299 p.

TANNERY, Paul. Mémoires Scientifiques. Toulouse, Édouard Privat, 1912. 5 v.

VERA, Francisco. Historia de las Ideas Matematicas. Bogota, Editorial Centro, 1943. 2 v.

\section{Biografias}

BELL, Eric Temple. Men of Mathematics. New York, Simon and Schuster, 1965. 590 p.

BÜHLER, Walter Kaufmann. Gauss: A Biographical Study. New York, Springler-Verlag, 1981. $208 \mathrm{p}$.

COOLIDGE, Julian Lowell. Mathematics of Great Amateurs. Oxford, Claredon, 1950. 211 p.

HEATH, Thomas Little. Diophantus of Alexandria: a Study in the History of Greek Algebra. New York, Dover, 1964. 387 p.

HOOPER, Alferd. Makers of Mathematics. New York, Random House, 1948. 402 p. 
INFELD, Leopold. Whom the Gods Love: the Story of Evariste Galois. New York, McGrawHill, 1948. 323p.

MAHONEY, Michael Sean. The Mathematical Career of Pierre de Fermat (1601-1665). New Jersey, Princeton University Press, 1973. 419 p.

World Who's Who in Science. Chicago, Marquis, 1968. 1855 p.

YOUNG, Laurence C. Mathematician and Their Times. Amsterdan, Nort-Holland, 1981.

\section{Por Assunto}

BARON, Margaret E. \& BOS, H.J.M. Curso de História da Matemática: Origens e Desenvolvimento do Cálculo. Brasília, Editora da UnB, 1985. 5 v.

BOYER, Carl Benjamin. The History of Calculus and its Conceptual Development. New York, Dover, 1959. $346 \mathrm{p}$.

DANTZIG, Tobias. Número: a Linguagem da Ciência. Rio de Janeiro, Zahar, 1970.

GROZA, Vivian Shaw. A Survey of Mathematical Elementary Concepts and their Historical Development. New York, Holt, Rinehart and Winston, 1968, 327 p.

IFRAH, Georges. Os Números: a História de uma Grande Invenção. Trad. de Stella Maria de Freitas Senra. Rio de Janeiro, Globo, 1989, 367p.

KARPINSKI, L. C. The History of Arithmetics. Boston, Rand McNally, 1925.

KNEALE, Willian \& KNEALE, Martha. O Desenvolvimento da Lógica. 1a ed. Trad. de M. S. Lourenço. Lisboa, Fundação Calouste Gulberkian, 1972, 770 p.

SANFORD, Vera. A Short History of Mathematics. New York, Houghton Mifflin, 1930. 402 p.

SMITH, David Eugene \& KARPINSKI, L. C. The Hindu-Arabic Numerals. Boston, Ginn and Company, 1911.

SMITH, David Eugene. History of Mathematics. Boston, Ginn and Co., 1923. 2 v. Vol. II, 725 p.

VAN DER WAERDEN, Bartel Leenert. A History of Algebra. Berlin, Springer-Verlag, 1985, $271 \mathrm{p}$.

VAN DER WAERDEN, Bartel Leenert. Geometry and Algebra in Ancient Civilizations. Berlin, Springer-Verlag, 1983. $223 \mathrm{p}$.

WILDER, Raymond Louis. Evolution of Mathematical Concepts. New York, John Wiley, 1973. $216 \mathrm{p}$.

\section{Outros}

AABOE, Asger. Episódios da História Antiga da Matemática. Trad. de João Pitombeira de Carvalho. Rio de Janeiro, Sociedade Brasileira de Matemática, 1984. 170 p.

BOLL, Marcel. As Etapas da Matemática. Lisboa, Europa-América, 1979. 164 p.

EULER, Leonhard. Cartas a uma Princesa de Alemania sobre Diversos Temas de Física e Filosofía. Ed. de Carlos Mínguez Péres. Zaragoza, Universidad de Zaragoza, 1990. $613 p$.

GILLINGS, Richard J. Mathematics in the Time of the Pharaohs. New York, Dover, 1972, 288 p.

HEATH, Thomas Litle. A History of Greek Mathematics. New York, Dover, 1981. 2 v.

LAUAND, Luiz Jean. Educação, Teatro e Matemática Medievais. São Paulo, Perspectiva/EDUSP, 1986, $117 \mathrm{p}$. 
MIDONICK, Henrietta O. (Ed.) The Treasury of Mathematics. New York, Philosofical Library, 1965. $820 \mathrm{p}$.

MIKAMI, Yoshio. The Development of Mathematics in China and Japan. New York, Chealsea, 1913, $347 \mathrm{p}$.

NEEDHAM, Joseph. Science and Civilization in China. Cambridge, University Press, 1959. 3 V.

NEUGEBAUER, Otto e SACHS, A. Mathematical Cuneiform Texts. New Haven, Conn. Yale University Press, 1945.

OLIVEIRA, Mario de. A Evolução do Pensamento Matemático na Grécia. Belo Horizonte, Fundação Cultural, 1980.

SMITH, David Eugene \& MIKAMI, Yoshio. A History of Japanese Mathematics. Chicago, 1912.

SMITH, David Eugene. A Source Book in Mathematics. New York, Dover, 1959. 2 v. 